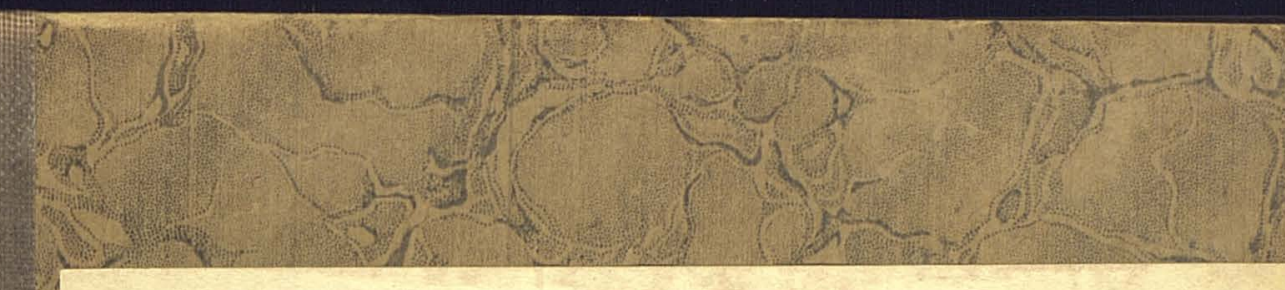

UNITED STATES GEOLOGICAL SURVEY

Bulletin 771

ORE DEPOSITS OF THE SADDLE MOUNTAIN AND BANNER MINING DISTRICTS, ARIZONA

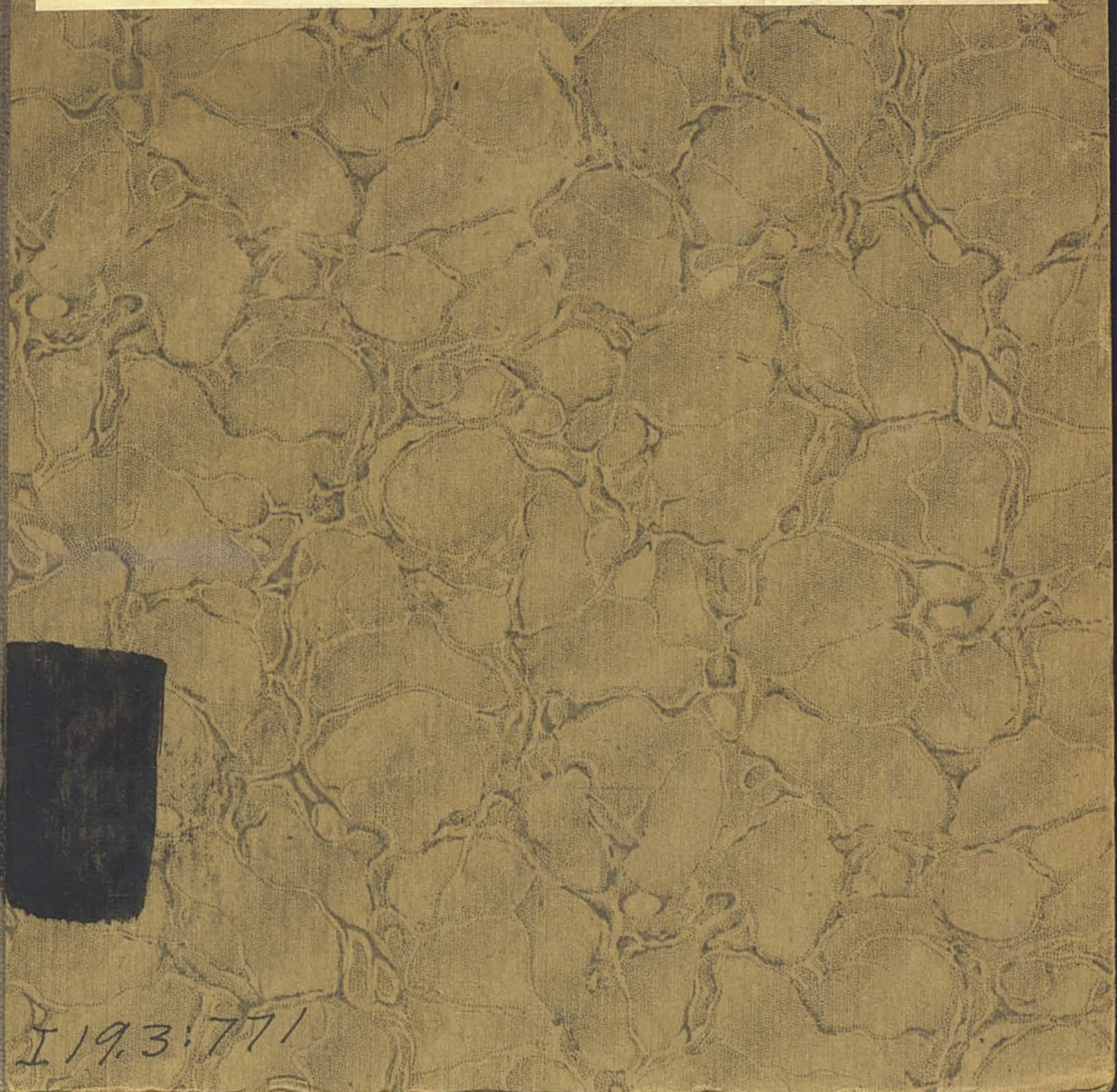





\section{Department of the Interior \\ Hubert Work, Secretary}

U. S. GEOLOGICAL SURVEY

- George Otis Smith, Director

\section{Bulletin 771}

\section{ORE DEPOSITS OF THE SADDLE MOUNTAIN AND BANNER MINING DISTRICTS, ARIZONA}

BY

CLYDE P. ROSS

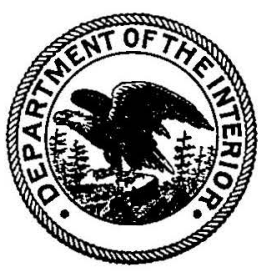

LIBRARY

TEXAS TECHNOLOGICAL COLLEGE LUBBOCK, TEXAS

WASHINGTON

GOVERNMENT PRINTING OFFICD

1925 
ADDITIONAL COPIES

OF THIS PUBLICATION MAY BE PROCURED FROM THE SUPERINTENDENT OF DOCUMENTS

GOVERNMENT PRINTING OFFICE

WASHINGTON, D. C.

25 CENTS PER COPY 


\section{CONTENTS}

\begin{tabular}{|c|c|}
\hline & Page \\
\hline Summary . & vII \\
\hline Introduction & 1 \\
\hline of the report. & 1 \\
\hline Location and extent of the area- & 2 \\
\hline Acknowledgments & 2 \\
\hline Topography & 4 \\
\hline Stratigraphy and petrology & 6 \\
\hline General features & 6 \\
\hline Paleozoic section & 6 \\
\hline Cretaceous stratified rocks & 11 \\
\hline Older Tertiary stratified rocks_. & 15 \\
\hline Gila conglomerate & 17 \\
\hline Quaternary alluvium & 18 \\
\hline Cretaceous intrusive rocks & 19 \\
\hline Quartz-hornblende diorite & 20 \\
\hline Quartz-mica diorite & 20 \\
\hline Structure & 21 \\
\hline Geologic history & 23 \\
\hline Ore deposits & 29 \\
\hline History and production & 29 \\
\hline Claim boundaries. & 30 \\
\hline Lead-silver veins & 30 \\
\hline - Pyritic gold deposits & 32 \\
\hline Disseminated pyrite deposits_. & 33 \\
\hline Contact-metamorphic deposits_. & 34 \\
\hline Generalizations and inferences & 39 \\
\hline Mines and prospects & 41 \\
\hline Adjust mine & 41 \\
\hline - & 43 \\
\hline - & 46 \\
\hline 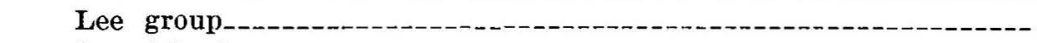 & 47 \\
\hline Carmichael group & 48 \\
\hline - & 48 \\
\hline 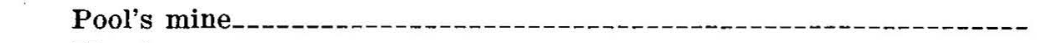 & 49 \\
\hline 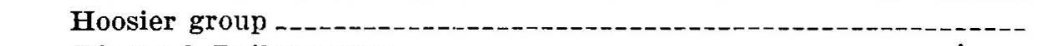 & 50 \\
\hline - & 51 \\
\hline Faull group_-_- & 52 \\
\hline - & 52 \\
\hline Mellor prospect._. & 60 \\
\hline London-Arizona mine & 61 \\
\hline Schneider group & 63 \\
\hline Apex mine & 63 \\
\hline Gold-Copper Mines Co & 64 \\
\hline Hogvall prospect & 65 \\
\hline
\end{tabular}


Mines and prospects-Continued.

Seventy-nine mine

Columbia mine-

McHur prospect

Premier group.-...

C. \& B. group

\section{ILLUSTRATIONS}

Plate I. Geologic map and section of the Christmas area

II. $A$, The upper part of the valley of Rock Creek; $B$, Lee Mountain and surrounding hills

III. Generalized columnar sections of Paleozoic rocks in regions near the Christmas area

IV. $A$, Cambrian quartzite on upper Ash Creek; $B$, Ripple-marked Cambrian quartzite on upper Ash Creek

V. $A$, Mottled Cambrian quartzite on upper Ash Creek; $B$, Tornado limestone in the box canyon on upper Ash Creek

VI. $A$, Coarse Cretaceous conglomerate on upper Ash Creek; $B$, Coarse Cretaceous conglomerate on Gila River above Apache Spring-

VII. A, General view of older Tertiary conglomerate north of Saddle Mountain ; $B$, Close view of older Tertiary conglomerate on west side of the Tablelands

VIII. A, Tuffaceous conglomerate of Tertiary age on the Tablelands ; $B$, Dike of quartz-mica diorite cutting Cretaceous volcanic rock on south side of Deer Creek east of Adjust mine.

IX. $A$, Contorted Tornado limestone on Gila River near southwest corner of the Christmas area ; $B$, Fault block of Tornado limestone on east side of Gila River near Apache Spring

$\mathrm{X}$. Property map of the Saddle Mountain and Banner mining districts

XI. A, Outcrop of Big Rock vein on Saddle Mountain group; $B$, Sill of altered trap in Tornado limestone on Gila River just south of the southern border of the Christmas area.

XII. A, Outcrop of gypsum on Little Gold Gulch; $B$, The old Christmas workings

XIII. Map showing relations of the stoped-out ore bodies of the Christmas mine to the surface geology

XIV. $A$, Contact-metamorphosed limestone north of No. 3 shaft, Christmas mine; $B$, Tunnels constituting the principal workings of the London-Arizona mine

XV. Geologic section through No. 3 shaft, Christmas mine

XVI. Geologic map of the part of the Banner mining district in the Ray quadrangle

XVIr. $A$, Curtin shaft; $B$, Workings on the Schneider group of the Gila Canyon Copper Co 
Figure 1. Index map showing location of the Saddle Mountain and Ban-

Page ner mining districts

2. Columnar section of Paleozoic rocks on upper Ash Creek..--

3. Section through the west end of the Tablelands, on line $B-B^{\prime}$, Plate I, showing relations of the Tertiary stratified rocks _.-

4. Blue Bird workings of Adjust Mining Co

15

5. Plan of principal workings at Little Treasure mine_-_____- 46

6. Geologic section through No. 1 shaft, Christmas mine 



\section{SUMMARY}

An area $7 \frac{1}{2}$ miles square in the southwest corner of the Christmas quadrangle, in Pinal and Gila counties, Ariz., was mapped geologically in the spring of 1922, and the ore deposits in the Saddle Mountain and Banner mining districts, which lie mainly in this area, were examined. The rocks of the two districts comprise pre-Cambrian Pinal schist; a considerable thickness of Cambrian, Devonian, and Carboniferous beds of marine origin; Cretaceous lava, pyroclastic rocks, and sedimentary beds; dioritic intrusions of probable early Tertiary age; Tertiary formations of volcanic and alluvial origin; and Quaternary alluvium of several ages. The Paleozoic succession just south of the Christmas area differs in a number of details from those both east and west. Some of the Cretaceous conglomerate is coarse and poorly sorted, and the possibility of a glacial origin is suggested. There is a strong unconformity at the top of the pre-Cambrian, but the Paleozoic formations, in spite of the great time gaps between them, are essentially conformable with one another. Erosion and some structural disturbance occurred after the deposition of the Carboniferous limestone, and further folding and faulting after the Cretaceous volcanism, with recurrent periods of faulting up to comparatively recent time.

Nearly 30 mines and prospects are described. Most of these were visited, but data for a few were gathered from other sources. All the ore deposits are believed to be genetically related to the intrusion of dikes and similar masses of quartz-mica diorite near the beginning of Tertiary time. The deposits in the area include lead-silver veins, pyritic gold deposits on shear zones, disseminated pyrite deposits, and contact-metamorphic deposits. Ore bodies of the last type have in different places been mined for copper, lead, zinc, and gold, and vanadium prospects have been opened on deposits that may be related to this type. As all the different types of deposits were formed during the same period of mineralization and all are related to the intrusion of the quartz-mica diorite it is to be expected that gradations between them may be found, and the veins and shear zones that are characteristic of the Saddle Mountain district may grade in depth into contact-metamorphic deposits such as are characteristic of the Banner district. 



\title{
ORE DEPOSITS OF THE SADDLE MOUNTAIN AND BANNER MINING DISTRICTS, ARIZONA
}

\author{
By Curde P. Ross \\ INTRODUCTION
}

Scope of the report.-The field work for this report occupied about two months in the spring of 1922 and included the geologic mapping of about 56 square miles in the southwest corner of the Christmas quadrangle and the examination of most of the mines and prospects in the Saddle Mountain and Banner mining districts. The area mapped includes the Christmas mine and will, for convenience, be referred to as the Christmas area. The mines and most of the prospects in the Saddle Mountain district and the part of the Banner district included in the Christmas area were studied in some detail, and most of those in the part of the Banner district lying in the adjacent Ray quadrangle were examined more briefly. There was little mining activity in either district when they were visited, and most of the larger mines were either in charge of caretakers or deserted. In consequence many of the workings were inaccessible.

The report is intended to give an idea of the character of the ore deposits in the two districts and the extent of their development. The general geology of the Christmas area is also discussed. Ransome $^{1}$ has described that of the Ray quadrangle, and the part of his geologic map of that quadrangle which includes the Banner district is reproduced on Plate XVI. A number of the ore deposits in that district are described in the Ray folio. The Christmas area includes all the known ore deposits of any consequence in the Christmas quadrangle. In the southeastern part of the quadrangle there are coal deposits that have been known for 40 years and prospected in a number of places, but little coal has ever been shipped, and no mining has been done since about 1907 . The essential facts regarding the coal fields are contained in a report by Campbell, ${ }^{2}$ and the avail-

${ }^{1}$ Ransome, F. L., Copper deposits of Ray and Miami, Ariz.: U. S. Geol. Survey Prot. Paper 115, 1919 ; U. S. Geol. Survey Geol. Atlas, Ray folio (No. 217), 1923.

'Campbell, M. R., The Deer Creek coal field, Ariz.: U. S. Geol. Survey Bull. 225, pp. 240-258, 1904. 
able data are summarized and brought up to date in a report on the Aravaipa and Stanley mining districts. ${ }^{3}$ The general geology of the Christmas quadrangle has been studied by Darton."

Location and extent of the area.-The Banner and Saddle Mountain mining districts lie respectively in Gila and Pinal counties, Ariz. They are in the southeastern part of the Mescal Mountains and include portions of the Ray, Christmas, and Winkelman quadrangles as mapped by the United States Geological Survey. (See fig. 1.) The portions in the Winkelman quadrangle contain no large prospects and were not studied during the present examination. Winkelman and Hayden, on the Arizona Eastern Railroad, are the principal shipping points for the two districts. Winkelman is somewhat over 70 miles by stage northeast of Tucson and 96 miles by railroad southeast of Phoenix. Hayden, at which there is a copper smelter of the American Smelting \& Refining Co., is 11/2 miles northwest of Winkelman.

The Saddle Mountain mining district is in Pinal County and may be approximately defined as the area southeast of Gila River, west of Reed Basin, and north of an east-west line passing through or just south of Saddle Mountain, a prominent landmark just south of the Christmas quadrangle, whose southern boundary crosses its north flank, the lower slopes lying in secs. 13 and 14, T. 5 S., R. 16 E., as shown on the map (Pl. I). This district was in the early days included in the San Carlos district. ${ }^{5}$

The Banner mining district is a triangular area in Gila County, bounded on the southeast by Gila River, on the north by Dripping Spring Valley, formerly known as Disappointment Valley, and on the southwest by the boundary between Gila and Pinal counties. The northwest end of this district is by some included in the Dripping Springs district. ${ }^{5}$

The Christmas area, shown on the geologic map (Pl. I), is a square $71 / 2$ miles on a side in the southwest corner of the Christmas quadrangle. This area includes all of the Saddle Mountain district in which there are prospects of any consequence and part of the Banner district. The western part of the Banner district is shown on Plate XVI.

Acknowledgments.--The mining men of both districts gave information and hospitality generously, and the assistance rendered by them is greatly appreciated. N. H. Mellor, O. L. Orem, and a number of others facilitated the examination of the Saddle Mountain district. J. N. Carmichael's claim map of that district was of much

s Ross, C. P., The geology and ore deposits of the Aravaipa and Stanley mining districts, Graham County, Ariz.: U. S. Geol. Survey Bull. 763, 1925.

- Darton, N. H., U. S. Geol. Survey Geol. Atlas, Christmas folio (in preparation).

ธ U. S. Geol. Survey Mineral Resources, 1907, pt. 1, p. 167, 1908. 


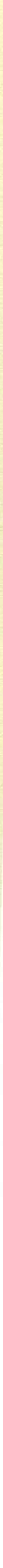


assistance. A. L. Gorman, of Christmas, made the stay there a pleasant one and contributed much information. At the other mines in the Banner district information was freely given by those in charge.

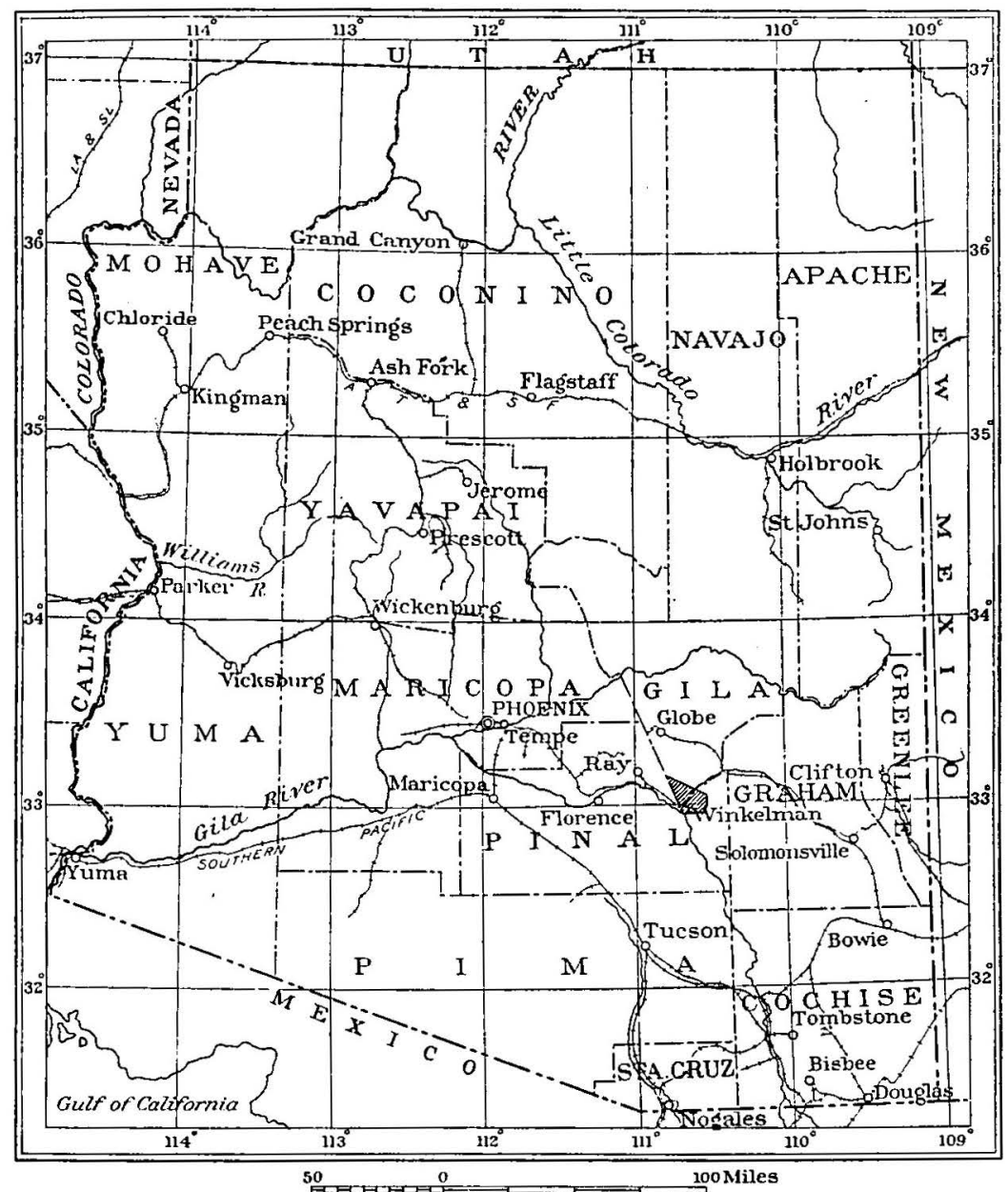

Figurn 1.- Index map showing location of Saddle Mountain and Banner mining districts, Ariz. (shaded area)

The officials of the Gila Copper Sulphide Co. generously gave access to a detailed geologic report on the Christmas mine by Augustus Locke and Guy N. Bjorge and furnished maps and other information. The data in the maps and report were freely drawn upon and were of much assistance in preparing the description of the Christmas mine. 


\section{TOPOGRAPHY}

The area here described contains the southeastern parts of the Mescal and Dripping Spring ranges separated by a depression occupied by different streams in different parts. The valley of Gila River cuts across both ranges and the intervening depression. The ranges are not so well defined in the area shown on Plate $I$ as in those to the north and west. The area is covered with rugged hills and mountains, which, with the exception of the mesa in the southeast corner and the sharp ridge in the northeast corner, show little regularity of form or system in arrangement. Few rise as much as 1,000 feet above their bases. The highest point is a peak in the Mescal Range, at an altitude of 4,755 feet above sea level, and the lowest is on Gila River, near the southwest corner, where the altitude is about 1,950 feet.

The only parts of the Mescal Range mapped are the sharp ridge already mentioned and the hills between it and Rock Creek. This is a subsidiary portion separated from the main range by Granite Basin, an intricately dissected depression, part of which is included at the northeast corner of the area mapped. The irregular hills south of the ridge and partly cut off from it by the narrow valley of Little Ash Creek rise to heights about 1,000 feet below the peaks on the ridge crest opposite them.

The depression between the two ranges is occupied by Dripping Spring Wash, Rock Creek, and Reed Basin. Dripping Spring Wash, which joins Gila River from the northwest, has a sandy flood plain from 500 to 2,000 feet in width. The stream has cut a shifting channel with steep banks a few feet high. There is water in the channel near the mouth, even in dry seasons, but it is derived from wells by means of which parts of the bottom lands are irrigated. The flood plain is bounded on both sides by scarps, above which the valley slopes gently up to the mountains on either side. The width of the open valley below the steeper mountain sides is about $1 \frac{1}{2}$ miles. The slopes are scarred by numerous precipitous-walled gulches so closely spaced as to divide the valley sides into a series of narrow, flat-topped ridges that trend almost at right angles to the main stream.

'The depression between the ranges is occupied for a short distance by Gila River and is continued southeastward by the valley of Rock Creek, which empties into the Gila over a mile upstream from the mouth of Dripping Spring Wash, but almost exactly in line with that stream. The creek is appropriately named. It has a linrow channel carved in rock, with numerous low waterfalls. The portion of the valley below the steep mountain sides has an 
average width of about 2,000 feet, and the streamward slopes are steeper than the corresponding slopes in Dripping Spring Valley. The tributary gulches have cliffs in many places, but they are not such narrow, nearly straight gashes in the valley sides as those tributary to Dripping Spring Valley. (See Pl. II, A.) Water seeps to the surface in a number of spots in the channels of the tributaries of Rock Creek even after long-continued dry weather. The differences in the two valleys result largely from the differences in the rocks underlying them, although the much greater length of Dripping Spring Valley has its effect also.

Ruck Creek is separated from Reed Basin by a poorly defined divide south of Corral Mountain. Reed Basin, of which only the west end is shown on Plate $I$, is a continuation of the depression between the ranges. It is, however, drained by Deer Creek, which leaves this depression through a gap in the southern rim of the roughly triangular basin and flows a little north of west through the Dripping Spring Range into the Gila. The valley of the portion of the stream which is shown on the map resembles that of Rock Creek, but is narrower, deeper, and steeper walled. Deer Creek differs from Rock Creek, however, in that the greater part of its channel is floored with a thin deposit of alluvium. Water flows at the surface in stretches of this stream in the driest seasons. Ash Creek, farther south, has a similar though more tortuous valley. Water flows at the surface in a large part of the channel of this stream also throughout the year.

The portion of the Dripping Spring Range included in the area mapped is an irregular group of low mountains that constitute part of the southeastern end of the range, which to the northwest assumes greater proportions and a more regular form. The highest. peak in this part of the range is Lee Mountain, which rises 3,787 feet above sea level (Pl. II, $B$ ); a number of the other peaks have altitudes of 3,000 feet or more. The Tablelands, which form a conspicuous feature of the southeast corner of the area mapped, have flat summits with altitudes of almost 3,500 feet.

The valley of Gila River cuts diagonally across the area. It has a sandy flood plain ranging from a few hundred feet to more than 1,000 feet in width, over which the river wanders in shifting channels with banks 1 foot to several feet high. Fragmentary terraces formed of unconsolidated or poorly consolidated alluvium border the flood plain in places, but for the most part the mountains rise abruptly from it. Water flows at the surface most of the year, but in very dry seasons some stretches of the bed are dry. 


\section{STRATIGRAPHY AND PETROLOGY}

\section{GENERAL FEATURES}

No rocks older than Carboniferous crop out in the area mapped. Above the limestone of that age are Cretaceous stratified rocks of volcanic and sedimentary origin, followed by Tertiary sand, gravel, tuff, conglomerate, and lava, with Quaternary alluvium in stream valleys. These rocks are intruded by quartz diorite of two types, probably of early Tertiary age. Strata older than Carboniferous crop out in the surrounding region and doubtless underlie the Christmas area also. There are differences in the Paleozoic sections to the east, west, and south. The Cretaceous rocks that crop out over the greater part of the Christmas area might in detailed work be subdivided on the basis of sedimentary and volcanic origin, but the rocks of the two types are so intimately interbedded that it proved impracticable to attempt such subdivision in the present work. The Tertiary stratified rocks can be grouped into five divisions, but the complete sequence is not exposed at any one place. 'The Quaternary allurium has been grouped into older and younger alluvium, and careful physiographic work would probably suggest further subdivision. Only the medium and coarser grained intrusive rocks have been mapped. Small dikes and irregular intrusions of fine-grained porphyritic rocks of diverse types are so numerous that to map them would be impracticable.

\section{PALEOZOIC SECTION}

No rocks older than Carboniferous crop out in the Christmas area, but immediately south of this area, on the upper part of Ash Creek, are excellent exposures of rocks ranging all the way from pre-Cambrian metamorphic rocks to the top of the Carboniferous limestone. The results of a paced traverse along Ash Creek through this section are given in Figure 2, and a comparison of this section with similar sections in neighboring regions is shown in Plate III. The top of the section is at the southern boundary of the Christmas area, a little over 11/2 miles from the southeast corner. A small area of the Carboniferous limestone of this section is shown on the map (Pl. I). At the base of the section is green and purplish schist which has the appearance characteristic of the Pinal schist ${ }^{8}$ of the Ray-Globe region, and, like that formation, is probably of preCambrian age. Above the schist is a metamorphosed sandstone in which bedding can be discerned. The strike is N. $80^{\circ} \mathrm{W}$., and the dip is about $50^{\circ} \mathrm{N}$. 'A dark-green gabbro crops out on both the up-

${ }^{\circ}$ Ransome, F. L., The copper deposits of Ray and Miami, Ariz.: U. S. Geol. Survey Prof. Paper 115, pp. 32-36, 1919. 
stream and downstream sides of the metamorphosed sandstone. The canyon walls above the metamorphic rocks are composed of Tertiary volcanic beds. The next rock encountered along the stream is a quartzite. This unconformity is taken to be the one that separates the pre-Cambrian and Paleozoic formations in the region, and the quartzitic strata above it are believed to belong to the Apache group ${ }^{7}$ (Cambrian?). The total thickness of the rocks that may be assigned to this group is only 600 feet, but the thickness in the GlobeRay region is over twice as much, as can be seen from Plate III. A number of the formations of the Apache group are either absent or are represented by beds differing lithologically from those in the Globe-Ray region. There is nothing corresponding to the Pioneer shale, and the Scanlan and Barnes conglomerates are represented only by small lenses of conglomerate and scattered pebbles near the base of the red cross-bedded quartzite, which is the lowest member of the group present. The pebbles are quartzose, and few exceed half an inch in diameter. The red and pink quartzite, about 210 feet thick, at the base of the group, probably corresponds to the Dripping Spring quartzite. The 90 feet of thinbedded green shale and red quartzite above this is probably equivalent to the Mescal limestone. The overlying 300 feet

I Idem, p. 39.

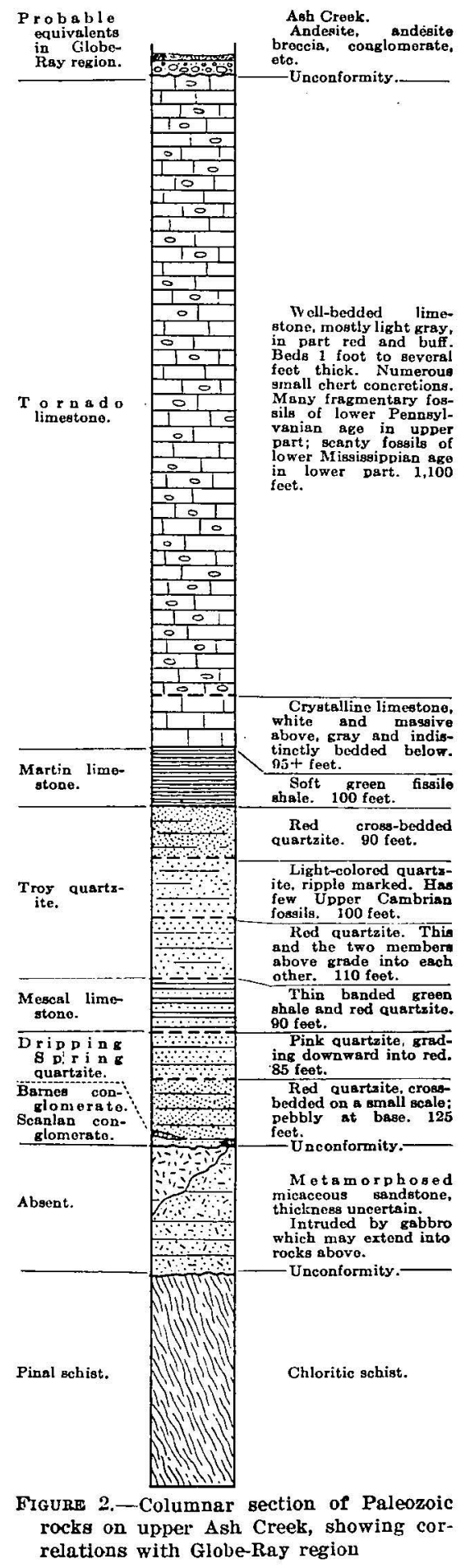
relations with Globe-Ray region 
of quartzitic beds may correspond to the Troy quartzite. The basalt present in many sections in the Globe-Ray region is absent here. The quartzite in this section is less metamorphosed than is characteristic of the Apache group in the Globe-Ray region. In most beds the original clastic grains can be seen with the unaided eye, bedding can be distinctly seen, and the rock in places might appropriately be called quartz sandstone. (See Pl. IV, A.) A number of the beds in the upper part of the section are beautifully ripple marked. (See Pl. IV , B.) Some of the beds near the top of the group have curious rounded protuberances on their surfaces. (See Pl. V, A.) The relief was doubtless produced by differential solution, but the reason for the selective action is not clear.

Some of the upper beds in the part of the section supposed to correspond to the Troy quartzite are sparingly fossiliferous. The few fossils collected here were examined by Edwin Kirk, who reports: "This lot is almost certainly of Upper Cambrian age. In the literature this horizon has variously been determined as Middle and Upper Cambrian. The best opinion at present, however, is that it should be referred to the Upper Cambrian." He identified the fossils as Obolus sp. and Lingulella sp. Campbell ${ }^{8}$ found fossils in these beds that were considered by Walcott to be of Middle Cambrian age: If the group is equivalent to the Apache group of Ransome, as the similarities in stratigraphic position and lithology make very probable, then it would appear from the determination cited that the whole of the Apache group is as old as Upper Cambrian.

The rock stratigraphically above the quartzite is green shale about 100 feet thick. It weathers readily into masses of soft flakes less than an inch in greatest dimension. No fossils were found in it. The stratigraphic position of this shale is apparently equivalent to that of the Martin limestone ${ }^{9}$ in the Globe-Ray region, and it may therefore be, like the Martin, of Devonian age.

The rest of the section measured is made up of limestone, with a total thickness of about 1,200 feet. The limestone can be subdivided into at least two parts on lithologic grounds, but the distinctions are so fine and the varieties merge into one another so gradually that even where the exposures are as excellent and complete as they are in this part of the valley of Ash Creek it would be difficult to set definite limits to the divisions, and it would be almost impossible to map them over any considerable area. The lower part of the limestone is light blue on fresh surfaces, crystalline, and massive. The thickness of limestone of this character is about 100 feet, but

\footnotetext{
${ }^{8}$ Campbell, M. R., The Deer Creek coa] Geld, Ariz.: U. S. Geol. Survey Bull. 225, p. 243,1904 .

- Ransome, F. L., op. cit., pp. 45, 46.
} 


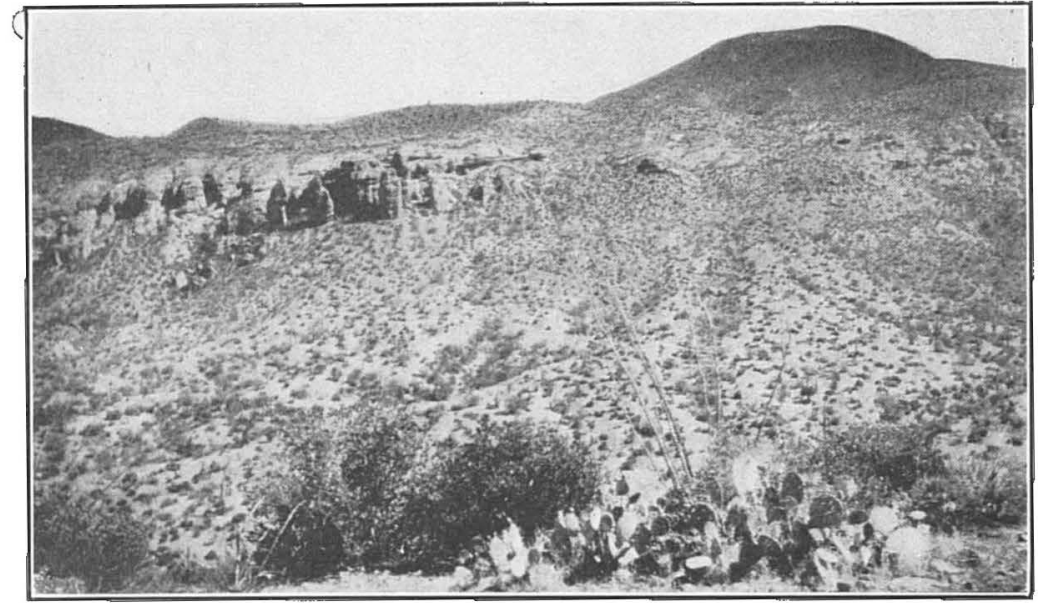

A. THE UPPER PART OF THE VALLEY OF ROCK CREEK

Shows the large valley occupied by a small stream. The prominent bluffs are composed of Gila conglomerate. Tertiary lava in the background and Cretaceous strati-
fied rocks in the foreground

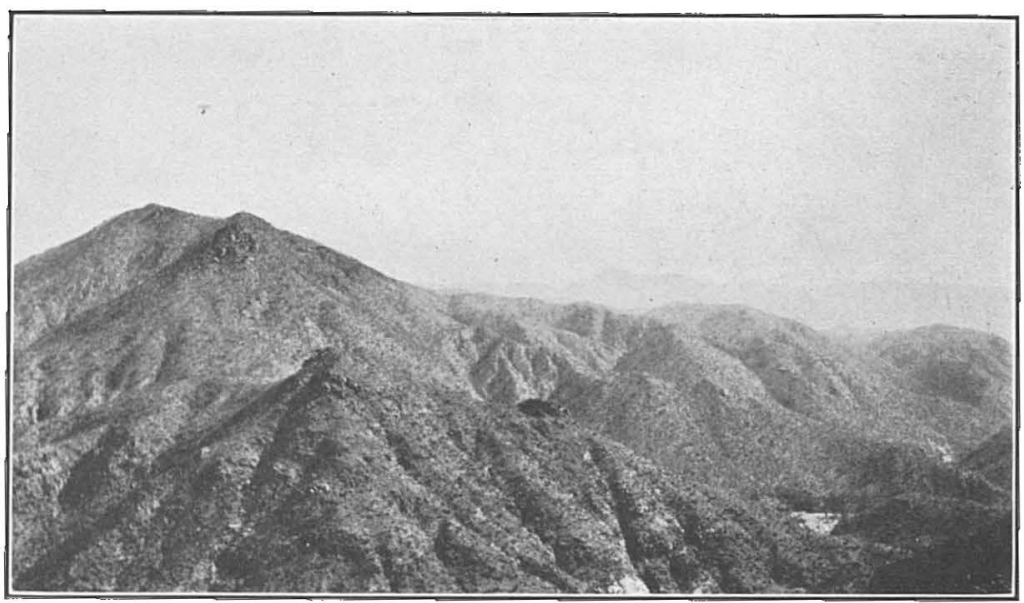

B. LEE MOUNTAIN AND SURROUNDING HILLS

Shows churacteristic topography of the Dripping Spring Range in the Christmas area. The rocks are principally Cretaceous lava and pyroclastic rocks 


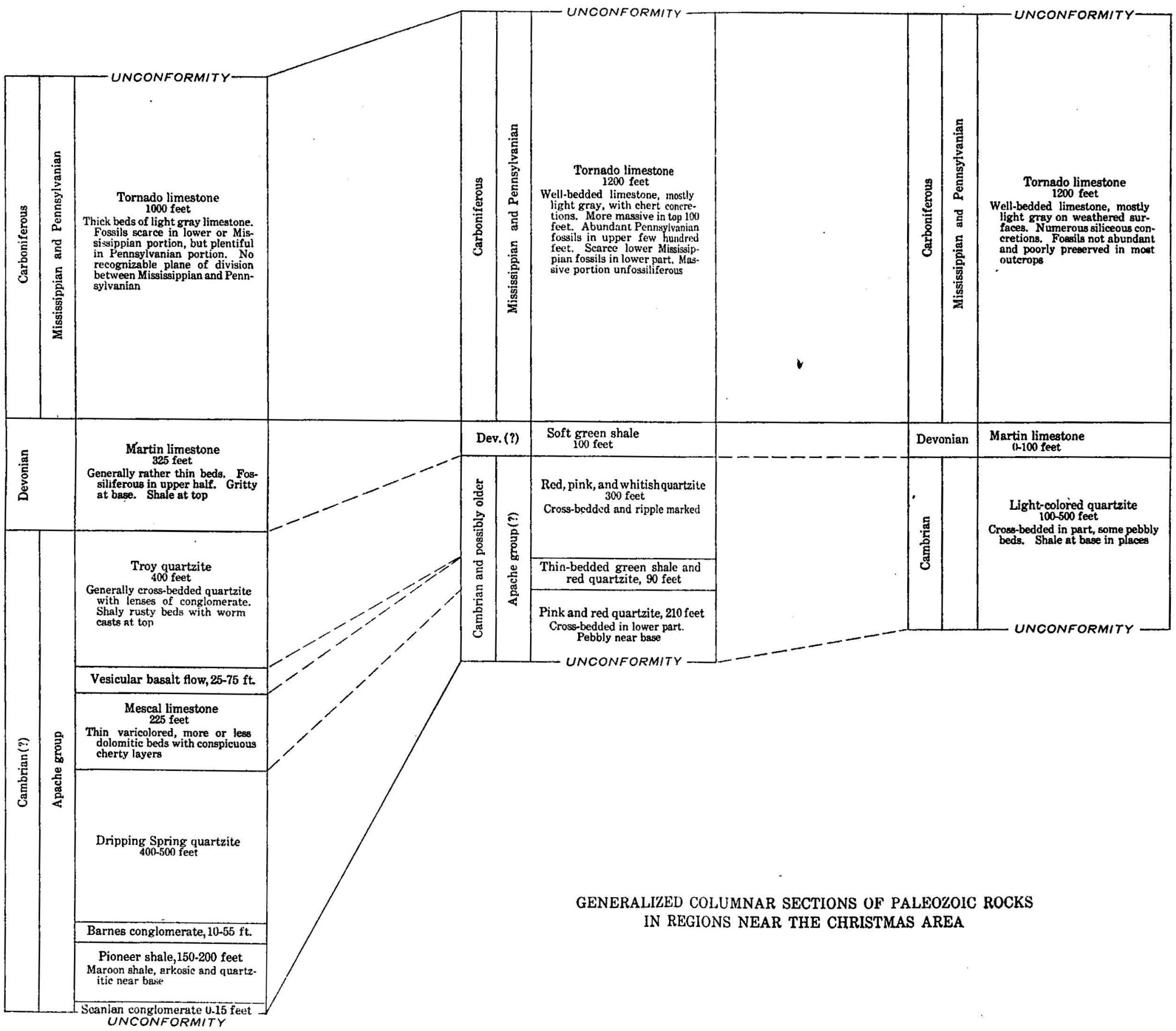




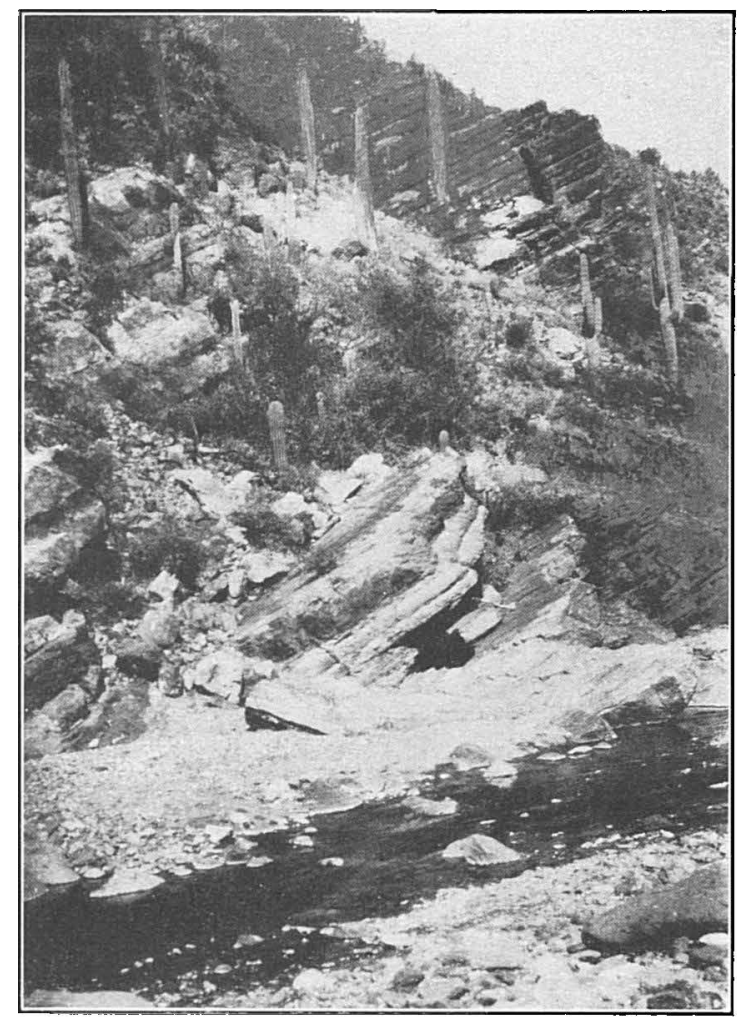

1. CAMBHIX QUARTZITE ON UPPER ASH CREEK, SHOWING BEDDING;

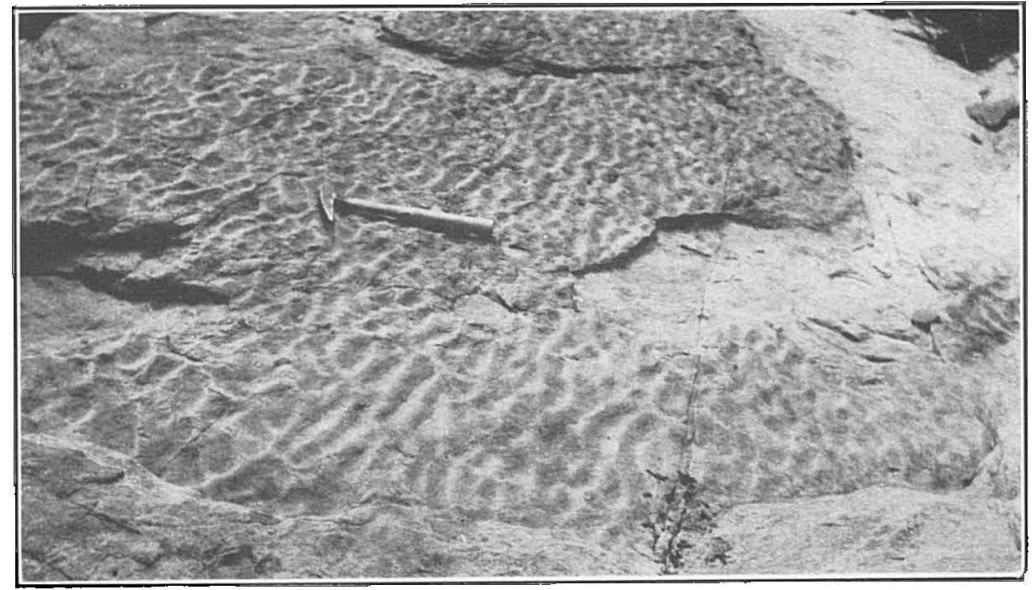

b. RIPPLE-MARKED CAUBRIAN QUARTZITE ON UPPER ASH CREEK 


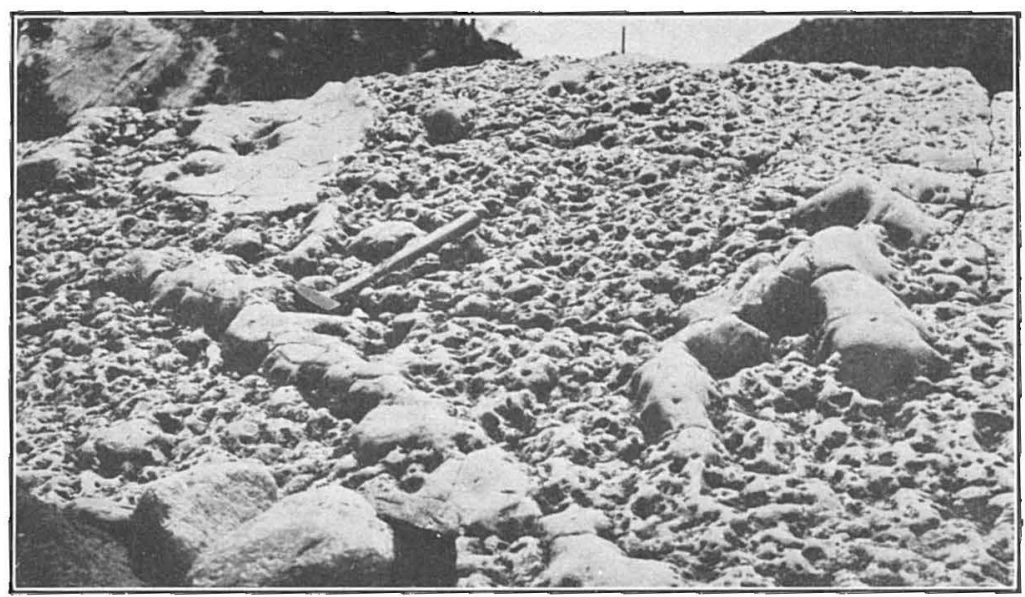

A. MOTTLED CAMBRIAN QUARTZITE: ON UPPER ASH CREEK

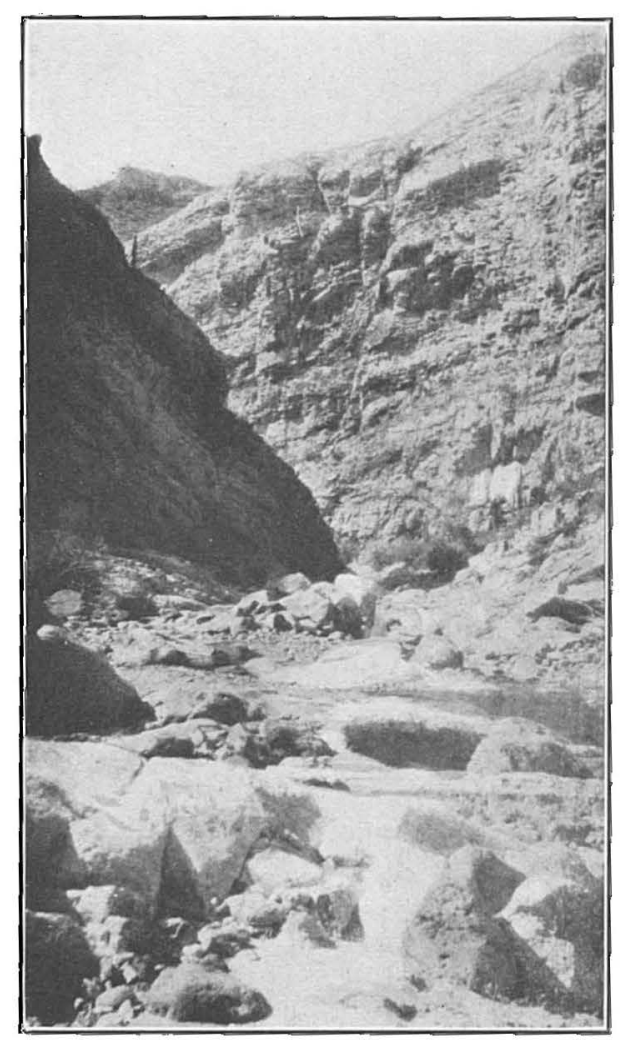

B. TORNADO LIMESTONE IN THE BUX CANYON ON UPPER ASH CHEEK 
the upper limit is indefinite. This part might be further subdivided into a lower half in which bedding can be discerned and an upper half in most of which there are no visible bedding planes. Above the 100 feet of comparatively massive limestone is about 1,100 feet of well-bedded limestone, most of which is light buff as exposed in the canyon walls. (See Pl. V, B.) The beds are from 1 foot to several feet thick and contain siliceous concretions stained yellow and red by iron oxides. The concretions are more numerous in the upper part of the section. The topmost limestone strata are in unconformable contact with beds of both Tertiary and Cretaceous age, and the measurement of the section could not be carried farther. At about the border between the well-bedded and massive limestones there are a few narrow bands containing small pebbles of metamorphosed trap. In the limestone in this vicinity traces of fossils were noted in a number of beds. A few that appeared sufficiently distinct to be determinable were collected and submitted to G. H. Girty for examination. In the beds near the top of the section fossils are abundant, but most of them are fragmentary. A collection from these beds was submitted to Mr. Girty at the same time, together with collections from similar limestone near Christmas and near the Lower Coal Field mine, on the north side of Reed Basin, 2 miles east of the east boundary of the area mapped on Plate I. Mr. Girty reports that the age of the collection from the lower horizon on Ash Creek can not be determined with any definiteness, but he believes "that it is probably lower Mississippian (Madison or Lake Valley)." The only form he identified in it is Triplophyllum sp. The collection from the upper part of the section is "definitely Pennsylvanian, and probably lower Pennsylvanian." The list of fossils identified in it follows:

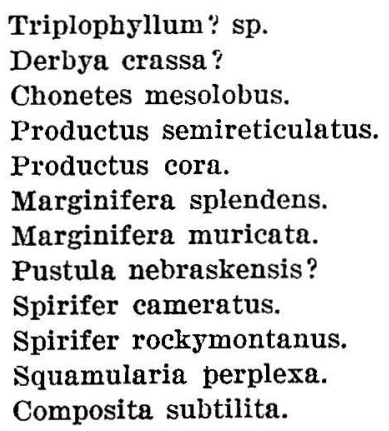

Campbell also collected fossils of Pennsylvanian age from the upper limestone beds.

From these paleontologic data and comparison with data from neighboring regions it appears probable that the entire 1,200 feet of 
limestone is equivalent to the Tornado limestone of Ransome ${ }^{10}$ and includes strata of Mississippian and Pennsylvanian age. In the area in the Winkelman quadrangle between the limestone on Ash Creek and the Tornado limestone in the Ray quadrangle are scattered exposures of similar limestone containing fossils of similar appearance. There are so many resemblances in lithology, stratigraphic position, and age between the limestone of Ash Creek and the typical Tornado limestone that the correlation is made with confidence.

Limestone similar to that on Ash Creek was found in several places in the Christmas area, and in these places the evidence for correlating it with the Tornado is even better. The crest and southern flank of the prominent ridge in the northeastern part of the area are composed of such rock, and the exposure can be traced continuously northwestward into the Ray quadrangle, where it joins a mass mapped by Ransome as Tornado (see PI. XVI). The fossils obtained near the Lower Coal Field mine came from the base of the ridge near the contact with the Cretaceous rocks and consequently from the top of the limestone section. Mr. Girty states that, like those from the upper beds on Ash Creek, they are "definitely Pennsylvanian, and probably lower Pennsylvanian." The list of fossils he identified in the collection follows:

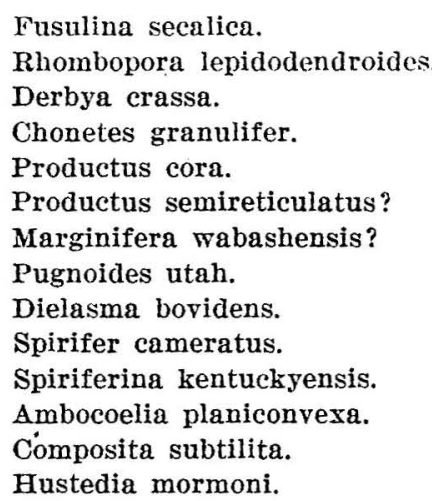

Near Christmas and in the southwest corner of the area there are masses of limestone which are eastward extensions of masses of Tornado limestone in the Ray quadrangle. (See Pls. IX, $A$, and XIII.) Small bodies of similar rock are brought up by a fault on the left side of Gila River near Sulphur Gulch. (See Pl. IX, B.) The fossils found near Christmas submitted to Mr. Girty proved to be indefinite. He states concerning this collection:

It may be Pennsylvanian, yet it obviously does not present the same facies as the two well-characterized Pennsylvanian faunas represented by the collections from Ash Creek and near the Lower Coal Field mine. On the other

${ }^{10}$ Ransome, F. I., op. cit., pp. 47-49. 
hand, it does not present any of the well-known lower Mississippian facies, though it contains nothing (unless it were the form called Derbya? sp.) that would debar it from the Madison or lower Mississippian. I should, however, prefer to call this lot Pennsylvanian rather than Madison. No upper Mississippian is known in this region, else it might even be upper Mississippian.

The list of fossils follows:

Cladochonus sp.

Derbya? sp.

Spirifer sp.

Composita aff. C. immatura.

Myalina sp.

In the part of the Banner district included in the Ray quadrangle the Paleozoic section corresponds essentially to the section for the Globe-Ray region shown in Plate III. For descriptions of these rocks the reader is referred to the work of Ransome. ${ }^{11}$

\section{CRETACEOUS STRATIFIED ROCKS}

Rocks of Cretaceous age crop out over more than two-thirds of the Christmas area. Considerable quantities of other rocks are found only along the northern border and in the southeast corner. The Cretaceous rocks include all the somewhat metamorphosed volcanic rocks and the sedimentary beds associated with them and can easily be distinguished from the Tertiary lava and tuff by their less tresh appearance.

There is doubtless much variation in the succession of beds in different places, and in the Christmas area no place was found where a satisfactory section could be measured. The thickness is certainly over 1,000 feet, and the maximum may be as much as twice that. It may be roughly estimated that two-thirds of the total thickness is of volcanic origin and the remainder of sedimentary origin. Probably in some localities the proportion of sedimentary beds is much less than this. The irregular distribution of sedimentary beds, the irregularity and indistinctness of stratification in the volcanic rocks, and the numerous faults make accurate estimates impossible. Evidently sedimentary beds occur at several horizons in the section. In Reed Basin there is much sedimentary rock, especially near the Lower Coal Field mine, east of the Christmas area, where according to an estimate by Campbell ${ }^{12}$ there is some 500 feet of sedimentary rock at the base of the Cretaceous section. In the valley of Little Rock Creek, especially on the left side, below the scarp of The 'Tablelands, are numerous beds of sedimentary rock,

\footnotetext{
II Ransome, F. L., The copper deposits of Ray and Miami, Ariz. : U. S. Geol. Survey Prof. Paper 115, 1919.

${ }^{12}$ Campbell, M. R., 'The Deer Creek coal field, Ariz.: U. S. Geol. Surrey Bull. 225, p. 246,1904 .
} 
principally conglomerate, but lava and pyroclastic rocks are interstratified with them. Along the portion of Deer Creek north of this locality there are beds of coarse conglomerate. On both sides of Ash Creek near the point where the stream crosses the southern border of the Christmas area are exposures of sedimentary rock, principally coarse conglomerate. Such beds form the base of the Cretaceous section and rest unconformably on the Tornado limestone. Others were noted interbedded with the volcanic strata on the slopes on either side. Near the head of Rock Creek, on the south side of the stream, are some thin beds of sandstone and conglomerate with rolcanic breccia stratigraphically above and below. 'The Cretaceous rocks between Little Ash Creek and Rock Creek contain a considerable proportion of sedimentary beds. In places sandstone rests directly on the Tornado limestone, the bedding in the two being nearly parallel. For hundreds of feet along the contact, however, a gray hornblende porphyry, eridently a lava flow, is the lowest member of the Cretaceous section. In the mountains on the east side of Gila River below the mouth of Rock Creek conglomerate and other sedimentary roclis are interbedded with the volcanic strata. Coarse conglomerate and sandstone occur on the west side of the Gila near the railroad tunnel. A mass of sandstone, shale, and conglomerate with subordinate volcanic material extends from a point about 1,400 feet southwest of the Two Queens mine northward to Deer Creek. The above include all the localities corered by the Cretaceous rocks in which any considerable quantity of sedimentary rocks were noted. Elsewhere the rocks are predominantly of volcanic origin.

Most of the sandstone is yellow on weathered surfaces, but beds containing considerable calcareous material are dark gray when broken. Some massive beds are several feet thick. The shale is composed largely of clay and carbonaceous matter. It is fine grained, and much of it is thin banded. The colors are light green, rarious shades of gray, and black. Indistinct evidence of plant remains was noted in a number of outcrops, and carbonized tree stumps are reported to have been found. ${ }^{13}$ No coal was noted in the Christmas area, but a little is supposed to have been found near the mouth of Little Ash Creek. Probably the major part of the sedimentary beds are conglomerates. Many contain pebbles or cobbles from a few inches to over a foot in cliameter, composed largely of quartz. quartzite, and various granitic rocks, mostly somewhat metamorphosed. Pebbles of limestone, probably from the Tornado, are present in some beds, and andesitic pebbles can also be found. The pebbles in many such beds are well rounded and fairly well sorted.

${ }^{13}$ Mellor, N. H., personal communication. 
These beds resemble the far older and more indurated Barnes conmlomerate of the Globe-Bay region, and it is conceivable that they have been derived in part from eroded outcrops of the Barnes. "There are also numerous thick beds in which most of the cobbles are composed of similar ancient quartzose and granitic rocks but are not well sorted and are in part subangular. Some of the cobbles in such beds are over 2 feet long. Typical examples are shown in Plate VI. Whether the pebbles and cobbles of ancient rocks were derived from the Barnes conglomerate or directly from the ancient rocks, it would seem that many of them must have been transported long distances. No rocks from which they could have come crop out in the Christmas area, and it is unlikely that any such rocks were exposed on the surface on which the Cretaceous beds were laid down. Some conglomerate beds are made up largely of fragments of the andesitic rocks. 'The pebbles in these beds are notably more angular than those composed principally of older rocks. In some the pebbles show little rounding. Beds that contain principally andesite pebbles lie stratigraphically both above and below beds that contain numerous pebbles of old rocks. Ransome ${ }^{14}$ reports that south of O'Carroll Canyon in the Ray quadrangle the Tornado limestone "is unconformably overlain by a layer of angular cherty fragments, derived from the limestone, embedded in a gray clayey matrix." Such material was not noted in the Christmas area.

Most of the volcanic strata are breccias of various types, although unbrecciated flows were noted in numerous places. Many of the flows. both brecciated and unbrecciated, have amygdalodial texture. The prevailing colors are purple and green, although various shades of gray, brown, red, and black were noted. Most of the lava is of andesitic composition, but basalt crops out over considerable areas. In many of the andesites the ferromagnesian minerals have broken down into epidote, chlorite, calcite, and other alteration products, but in some of them hornblende is a prominent constituent. The feldspar is clouded with opaque dust and alteration products and ranges in composition from oligoclase to andesine. The basalt examined is a fine-grained black rock consisting essentially of bytownite feldspar and biotite, with much chlorite and epidote, some calcite, and other alteration products.

Near the head of Little Rock Creek is an outcrop of a drab andesite cut by ramifying dikelets of smoke-gray sandstone a few inches wide. The andesite is composed predominately of feldspar microlites of about the composition of oligoclase, with epidote and other alteration products. There are a few small lath-shaped oligoclase phenocrysts. The

${ }^{1+}$ Ransome, F. L., The copper deposits of Ray and Miami, Ariz.: U. S. Geol. Survey I'rot. I'iper 115, 56-57, 1919. 
sandstone is fine to medium grained and is composed largely of quartz and altered feldspar with some epidote and chlorite. Clastic dikes in the Cretaceous rocks of this region were also observed by Campbell, ${ }^{15}$ but those he examined had a filling of conglomerate instead of sandstone.

The determination of the age of the volcanic and sedimentary strata described above rests largely on evidence obtained in the region east of the Christmas area, as no identifiable fossils have been found in them within that area. The stratigraphic evidence in the Christmas area shows that the rocks are younger than the Tornado limestone, on which they rest unconformably, and antedate the older Tertiary beds, which lie unconformably on them. The angular discordance between the Tornado limestone and the overlying beds is so slight that in most exposures it is imperceptible. The only place where a marked difference in the attitude of the beds was observed was on upper Ash Creek, and here the structure is complicated by small normal faults. The presence of an unconformity is attested, however, by minor irregularities in the contact as exposed along Little Ash Creek and by the sharp change in lithologic character. The unconformity at the base of the Tertiary beds can be seen by a glance at the map (Pl. I). In the northwestern part of the area Tertiary strata dipping gently southwestward rest on the truncated edges of more steeply inclined Cretaceous beds. In the southeast corner of the area the Cretaceous beds dip northwest and the Tertiary strata above them dip east.

The Cretaceous beds can be traced in continuous exposures eastward through the coal fields into the Stanley mining district. On the basis of collections of imperfectly preserved leaves and shells Walcott ${ }^{16}$ and Campbell ${ }^{17}$ both considered the corresponding rocks to be of Cretaceous age. A recent collection of invertebrate fossils found near the base of the Cretaceous in the Stanley mining district $^{18}$ was examined by $T$. W. Stanton, who states that they are of Colorado age. Thus the sedimentary beds in the lower part of the formation were clearly laid down in the early part of Upper Cretaceous time. Fossils have not been found in beds in the upper part of the formation, but it is probable that the whole group of volcanic and sedimentary beds was deposited in Upper Cretaceous time.

\footnotetext{
${ }^{15}$ Campbell, M. R., Conglomerate dikes in southern Arizona: Am. Geologist, vol. 33, pp. $13 \check{2}-138,1904$.

${ }_{10}$ Walcott, C. D., and Bannon, M., Deer Creek coal field, White Mountain Indian Reservation, Ariz. : 48th Cong., 2 d sess., S. Ex. Doc. 20, p. 7, 1885.

${ }^{17}$ Campbell, M. R, 'The Deer Creek coal field, Ariz.: U. S. Geol. Survey Bull. 225, p. 240,1904 .

${ }^{18}$ Ross, C. P., The geology and ore deposits of the Aravaipa and stanley mining districts, Graham County, Ariz.: U. S. Geol. Survey Bull. 763, 1925.
} 


\section{OLDER TERTIARY STRATIFIED ROCKS}

The bedded rocks younger than the Cretaceous rocks just described and older than the Gila conglomerate may be termed older Tertiary stratified rocks. They consist of rocks of both sedimentary and volcanic origin and have yielded no fossils. Four divisions were mapped in the southeast corner of the area, where the rocks are well exposed. (See fig. 3.) The same divisions were recognized in the outcrops betwcen the main ridge of the Mescal Range and Rock Creek, but with a number of differences, particularly in the thickness. The lowest division, although probably present in places, was so scantily represented that it could not be mapped in this part of the area. It bears a striking resemblance to the well-known Gila conglomerate, as can be seen from Plate VII. It is tentatively correlated with the Whitetail conglomerate of the Globe-Ray region, as it is similar in age, stratigraphic position, and origin to that formation. As can be seen from Plate $I$, its thickness is variable. The

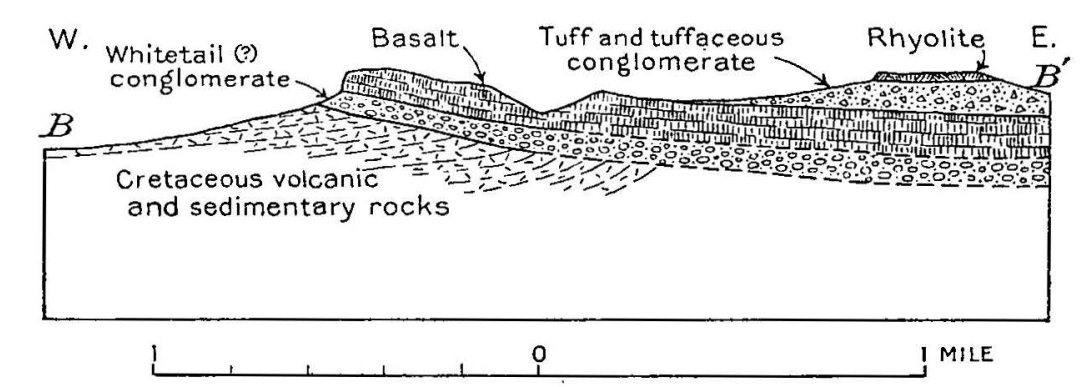

Figdrm 3.-Section through the west end of The Tablelands, showing relations of the 'Tertiary strata. For line of section see $B-B$ ', Plate I

maximum is about 400 feet on upper Ash Creek. The exposure around the rim of The Tablelands decreases gradually in thickness to the northeast. At a point 2,000 feet west of the east border of the area mapped none of the rock is visible, but east of this point the thickness again gradually increases. A little red gravel can be found in places at the base of the Tertiary section in the outcrops north of Rock Creek, and this is doubtless equivalent to that underlying The Tablelands. Its thickness in this part of the area is nowhere more than a few inches.

In the scarp of The Tablelands the material of the lowest division is coarse sand and gravel, sufficiently indurated to form steep slopes and small cliffs but easily broken down by a pick. The deposits are distinctly bedded but not well sorted. The fragments composing the beds range in size from coarse sand up to cobbles 2 feet long. Most of them are subangular, but in some beds the pebbles are fairly well rounded. The material is derived in large part from the Cretaceous 
rocks beneath. Pebbles of ancient rocks are present in some beds, but these may come from the Cretaceous conglomerate. (See Pl. VII, B.) Viewed from a distance most of the deposits are light brown, but some exposures appear almost cream-colored. In places the beds immediately below the lava have been baked to a dark red by heat from the igneous rock, and are much harder than the rest of the deposit. As already stated, this formation, which is mapped as Whitetail (?) conglomerate, rests with angular conformity on the Cretaceous stratified rocks below The Tablelands. Near the south edge of the area mapped it extends beyond this formation and overlaps on the tilted surface of the Tornado limestone.

The next succeeding unit of the Tertiary bedded rocks is basalt. In the scarp of The Tablelands this rock can be seen to rest on the Whitetail (?) conglomerate just described with a small angular discordance. The dip of the lava is in approximately the same direction as that of the alluvial deposits but gentler. The maximum thickness of basalt on The Tablelands is approximately 500 feet. Northwest of Corral Mountain the thickness is of the same order of magnitude, the maximum being perhaps somewhat greater. These thicknesses have been built up by successive flows, some of them only a few feet thick.

The basalt in the southeastern part of the region is a fine-grained black or brown rock, sparingly vesicular, consisting of augite and olivine, with some iddingsite and epidote. In the vicinity of Corral Mountain much of the rock is dark red and highly vesicular.

The unit next above the basalt consists of tuff and tuffaceous conglomerate of siliceous composition. In the conglomerate on The Tablelands the pebbles are subangular, and range from a fraction of an inch to a few inches in greatest dimensions. Most of them are composed of a dark-gray aphanitic rock with pronounced. flow structure and tiny phenocrysts of quartz and feldspar. It is a soda rhyolite consisting essentially of quartz and alkali feldspar, in part albite. A characteristic exposure of such beds is shown in Plate VIII, $A$. The thickness in the western part of The Tablelands is somewhat over 300 feet. In the area north of Rock Creek there is a similar tuffaceous conglomerate containing pebbles of rhyolite, basalt, and pumice in a nearly white matirx of tuff. The thickness is nowhere more than a few score feet, and in places it is not exposed. On Corral Mountain there is a small amount of tuffaceous conglomerate at the base of and also interbedded with the lava that caps the mountain, but as the maximum thickness observed was only about 20 feet it was not mapped.

The tuffaceous beds are capped by lava flows of variable composition. In a number of places the rock is dark gray or purplish, shows a few phenocrysts of quartz and alkali feldspar in a ground- 


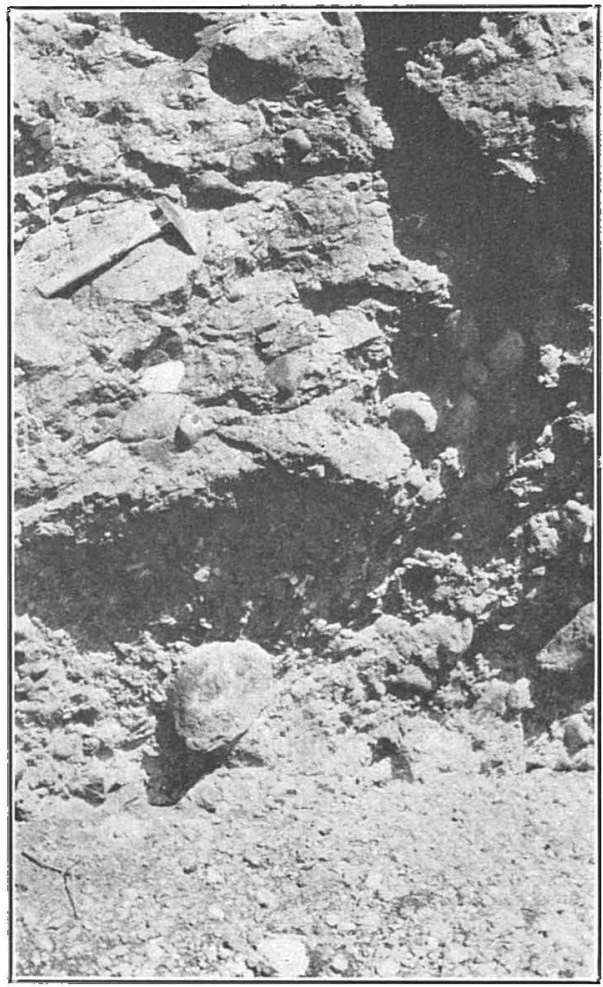

A. COARSE CHETACEOUS CONGISMERATE ON UPPER ASH CHELK

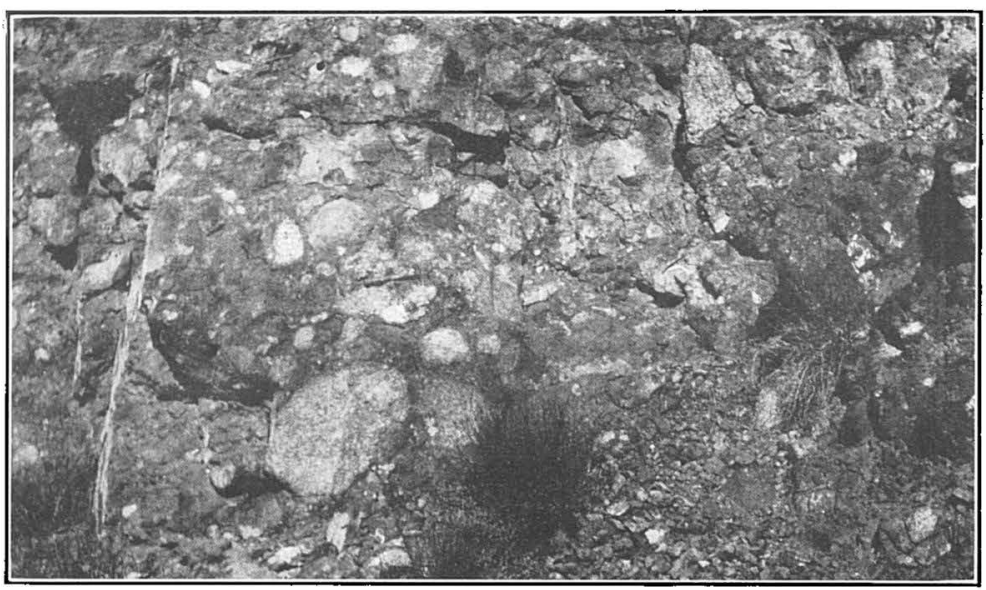

B. COARSE CRETACEOUS CONGLOMERATE ON GILA RIVER ABOVE APACHL: SPRING 


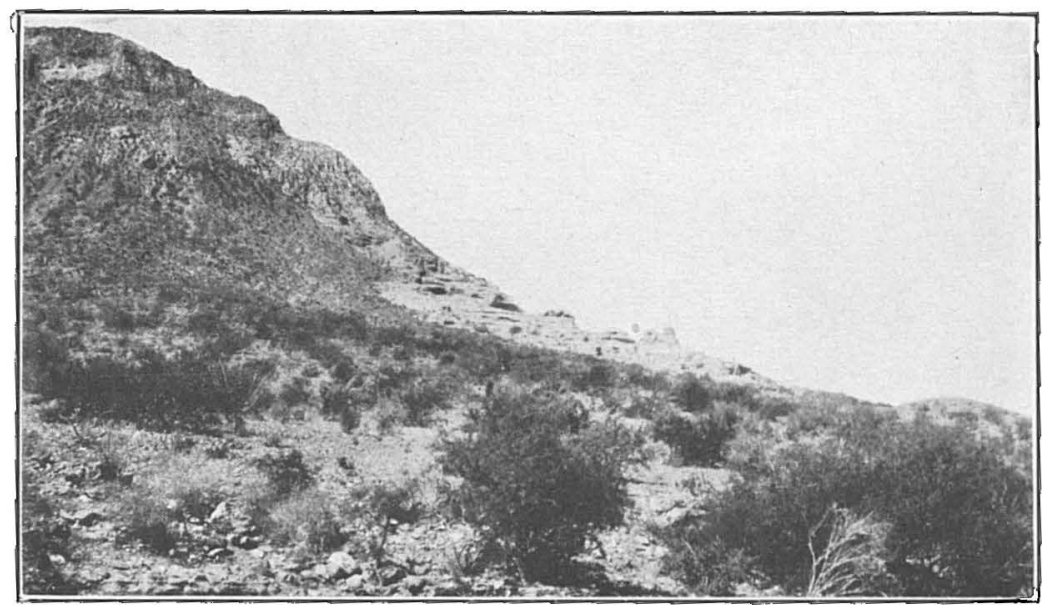

A. GENERAL VIEW OF OLDER TERTIARY CONGLOMERATE NORTH OF SADDLE MOUNTAIN

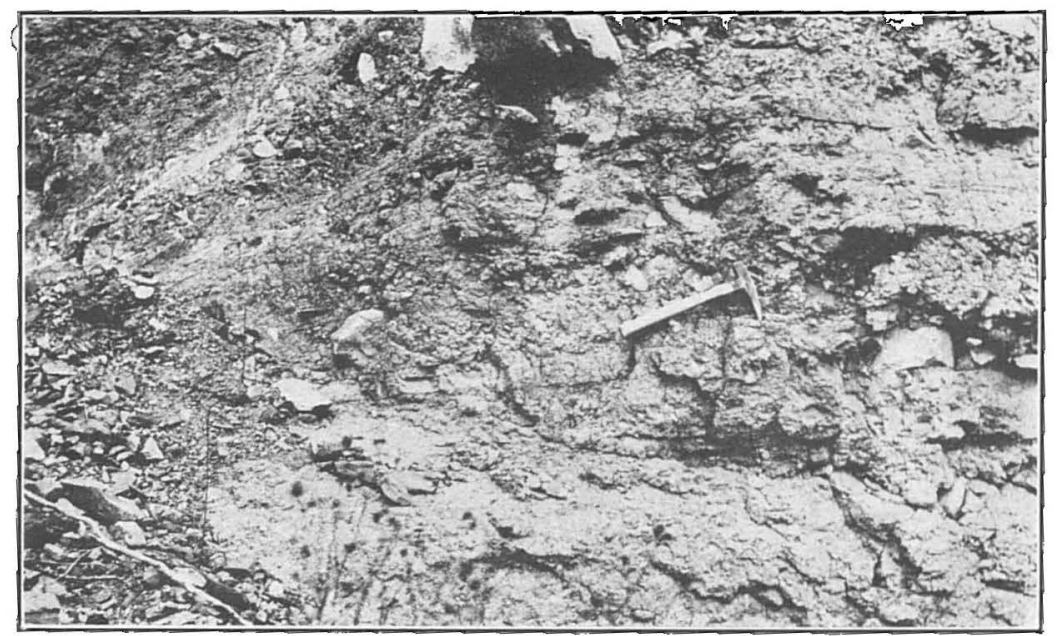

B. CIOSE IIEW OF OLDER TERTIARY CONGLOMLHATE ON WLST SIDE (OF TULE TABIELANIS 


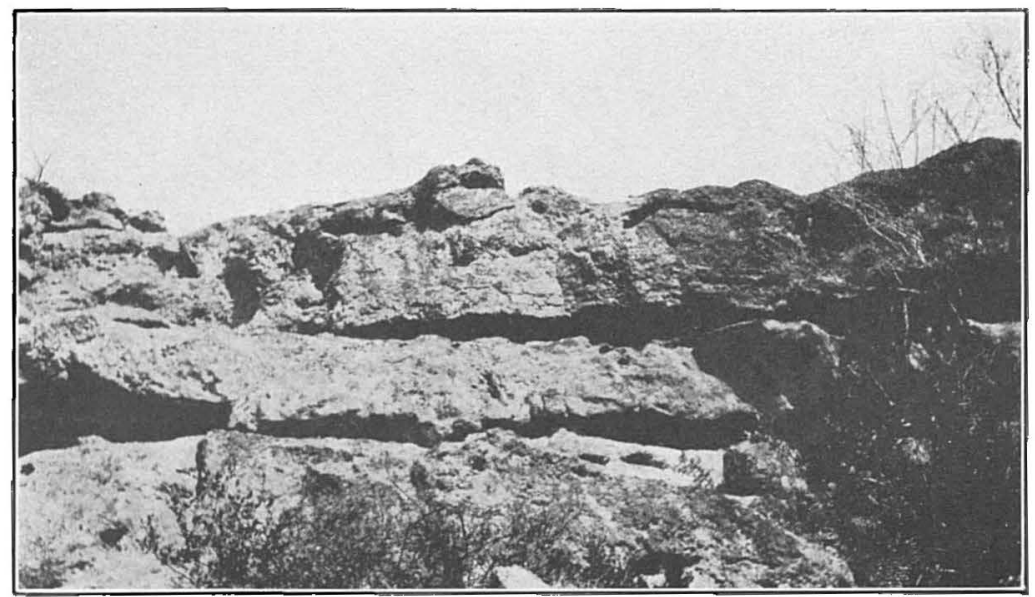

A. TUFFaCeOUS Conglomerate of TERTIARY AGE ON THE TABLELANDS

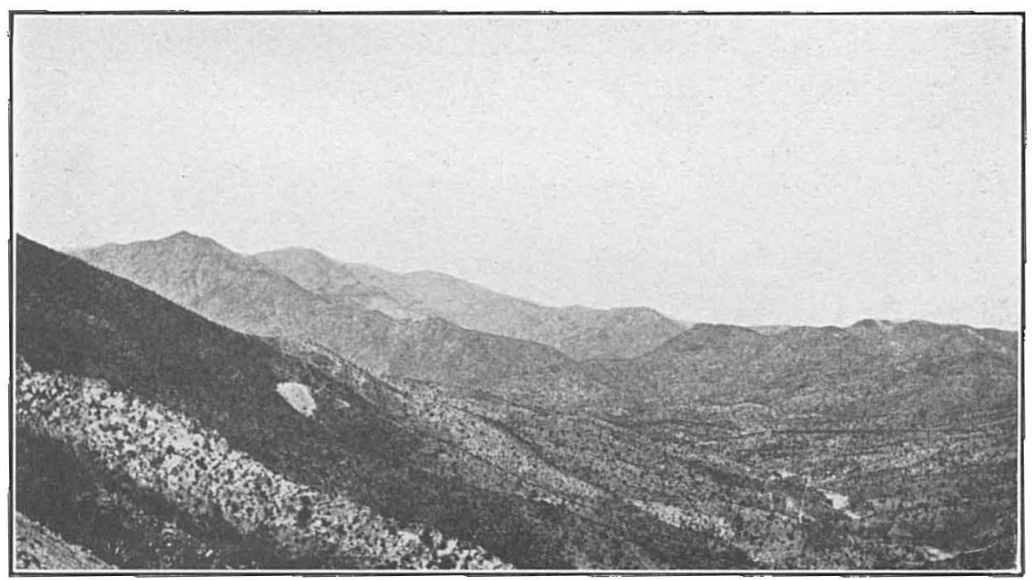

B. DIKE OF QUARTZ-MICA DIORITE CUTTING CRETACEOUS VOLCANIC HOCK ON SOUTH SIDE OF DEER CREEK EAST OF ADJUST MINE 


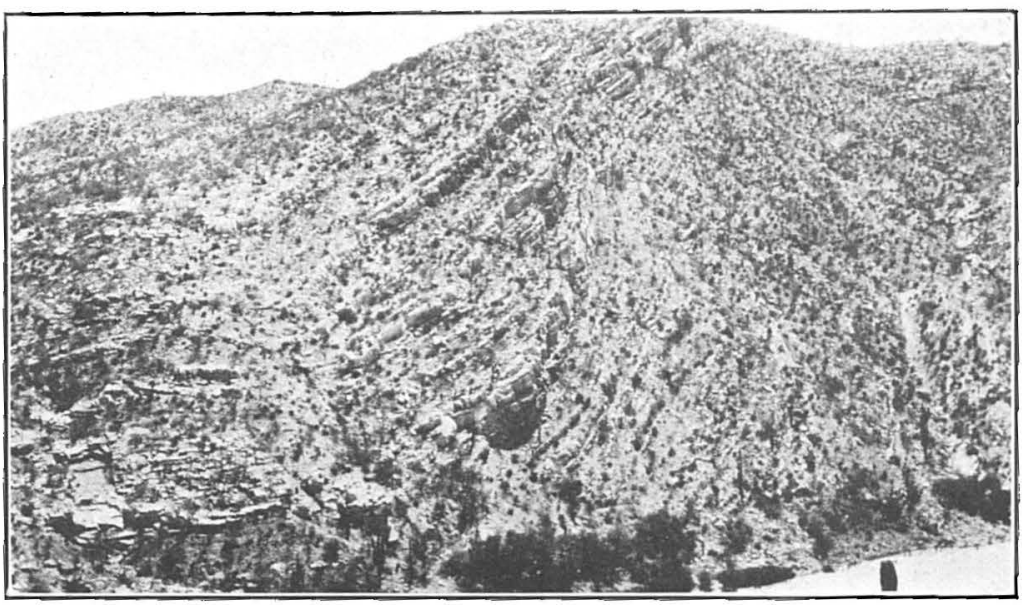

A. CONTORTED TORNADO LIMESTONE ON GILA RIVER NEAR SOUTHWEST CORNER OF CHRISTMAS AREA

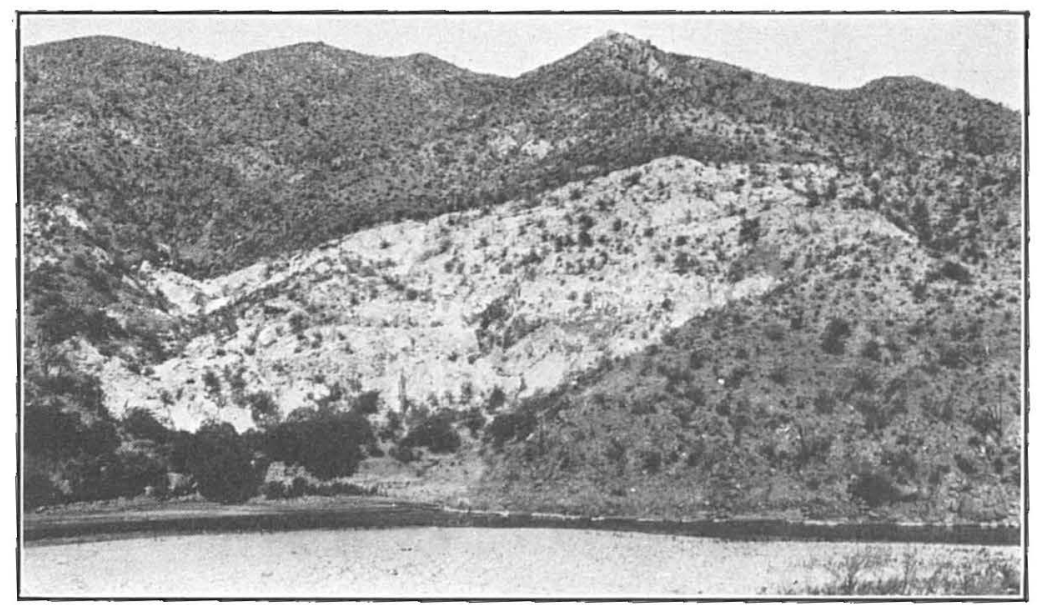

B. FAULT BLOCK OF TORNADO LIMESTONE ON FAST SIDE OF GIIA RIVER NEAR APACHE SPRING

The limestone is in part contact metamorphosed, and prospecting has been done in it 
mass of devitrified glass with flow structure, and has the composition of a rhyolite or quartz latite, and this name is consequently used on the map. In places, however, the lava in this stratigraphic position is basalt. The lava that caps the small mesa on The Tablelands near the southeast corner of the area, marked on Plate $I$ by the altitude figure 3535 , is basalt containing bytownite feldspar, epidote, and iddingsite. The original ferromagnesian minerals were probably olivine and augite, but they are now almost completely destroyed by alteration.

The Whitetail (?) conglomerate, basalt, tuff and tuffaceous conglomerate, and rhyolite described above are clearly of Tertiary age. They are youngè than the Cretaceous stratified rocks and older than the Gila conglomerate, which is believed to be of Pliocene and Pleistocene (?) age. In the absence of fossils the date of formation can not be more closely fixed with certainty. They are contemporaneous with part of the Teritary volcanic rocks in the Stanley mining district, a few miles farther east.

\section{GILA CONGLOMERATE}

The poorly consolidated alluvial deposits that occupy the greater part of Dripping Spring Valley belong to the Gila conglomerate. Remnants of the same formation crop out on the north side of Rock Creek. (See Pl. III, A.) Beds mapped as belonging to the Gila conglomerate are coextensive with beds so assigned by Ransome ${ }^{19}$ in the portion of Dripping Spring Valley that lies in Ray quadrangle.

Thicknesses of several hundred feet of the formation are exposed in the Christmas area, and much of it has obviously been removed by erosion. The formation is made up of conglomerate and coarse sandstone, which is sufficiently cemented to stand up in cliffs but is not hard. The material is in the main poorly sorted and subangular, as is characteristic of the formation in most localities where it has been observed. The pebbles are derived from the Paleozoic strata, especially the quartzites, from various granitic rocks, and from Cretaceous volcanic rocks, and, chiefly on Gila River and north of Rock Creek, there are beds in which fragments of Tertiary basalt and ryholite are abundant. It is clearly younger than any of the formations of which it contains fragments. In San Pedro Valley, in the Winkelman quadrangle, south of the Christmas area, fossils of Pliocene age ${ }^{20}$ have been found in rock believed to belong to the Gila formation. ${ }^{21}$ On this evidence the Gila conglomerate in the

${ }^{10}$ Ransome, F. L., op. cit., pp. 71-74.

${ }^{20}$ Gidley, J. W., Preliminary report on fossil vertebrates of the San Pedro Valley, Ariz.: U. S. Geol. Sulvey Prof. Paper 131, pp. 120-121, 1922.

2 Bryan, Kirk. personal communication. 
Christmas area may be provisionally considered as at least in part of Pliocene age.

\section{QUATERNARY ALLUVIUIM}

All the alluvial deposits younger than the Gila conglomerate may be grouped under the name Quaternary alluvium. Two divisions are recognized, and physiographic study would probably reveal more. The older alluvium includes the partly consolidated deposits, remnants of which can be found on slopes above the present flood plains. Patches of it have been mapped in several places along Gila River, on Ash Creek below the Two Queens mine, and on a ridge south of O'Carroll Canyon. On the north side of Deer Creek nearly a mile above its mouth and at Christmas there are slopes whose smooth contours contrast sharply with the dissected hillsides around them. These slopes are veneered with cemented gravel, which has been mapped as belonging to the older alluvium. There are in places patches of older alluvium so small and irregular that they have not been mapped. One such place is on upper Ash Creek near the southern boundary of the Christmas area. Alluvium of this age may be present in the parts of the area mapped as underlain by the Gila formation.

The second division of the Quaternary alluvium may be termed Recent alluvium. It occupies the channels and flood plains of the present streams. It has been mapped only in the flood plains of Gila River and Dripping Spring Wash, where the width is sufficient to warrant showing it. On Deer Creek gravel and sand occur for the first mile and a half above its mouth and from a point near the mouth of Little Rocky Creek upstream. In the intervening stretch the amount of gravel on the bedrock along the stream is small. There is a width of 100 feet or more of Recent alluvium along the whole of the portion of Ash Creek in the Christmas area. Recent alluvium occurs near the mouths of nearly all the streams emptying into the Gila, and many others have small amounts of gravel in places in their channels.

The older alluvium is in general a coarse, poorly sorted gravel composed of subangular to rounded fragments of Tertiary and older rocks. Most of it is more or less cemented with caliche. It is of either Pleistocene or Recent age. Part of the material mapped as older alluvium at Christmas consists of large angular blocks of andesitic rock and diorite porphyry and is probably talus, but some of it shows evidence of sorting by water. Some of the talus material may be of recent origin.

The Recent alluvium is unconsolidated. The flood-plain deposits mapped consist of sand and silt. The material in the smaller stream channels is coarse sand, gravel, and boulders. The boulders are 
all of local derivation, and most of the gravel has not been carried far. On Ash Creek, however, limestone and basalt pebbles were noted several miles below outcrops of such rocks.

\section{CRETACEOUS INTRUSIVE ROCKS}

The Cretaceous stratified rocks are everywhere cut by numerous small masses of fine-grained porphyritic rocks which may for purposes of description be grouped together. Many are similar petrographically to the flows and evidently are genetically related to them; others may be of later origin. Probably most of these intrusive bodies are dikes, but there are also a number of sills and irregular masses. Although the aggregate area of outcrop of such rocks in the Christmas region is large, most of the individual masses are so small and their relations are so complex that they could not be mapped without the expenditure of an undue amount of time. The dikes range in width from a few feet to more than 100 feet. Some of them may be traced for a few hundred yards, but most are shorter. The sills have about the same range in climensions as the dikes. Some of the irregular masses may be as much as a few thousand feet in greatest dimension. In many places it is difficult to be sure whether a given mass is of effusive or intrusive origin.

These intrusive rocks have about the same range in color and composition as the Cretaceous lavas. Among the colors noted are purplish, green, black, brown, and gray. The greater part are andesites; consisting largely of hornblende and either oligoclase or andesine. There are a few masses of quartz latite containing oligoclase, orthoclase, hornblende, and quartz, and others of basalt containing augite, olivine, and calcic plagioclase. Most of them contain variable amounts of chlorite, calcite, sericite, and other alteration products.

Most of these porphyritic rocks may be confidently considered to belong to the same period of volcanism as the lava and associated strata which they cut, and they are consequently of Cretaceous age. There are, however, bodies of light-gray andesite, consisting essentially of hornblende and oligoclase, some of which may be related to the diorite dikes described below and consequently probably of early Tertiary age. This suggestion is founded on Ransome's observation ${ }^{22}$ that in the vicinity of Troy, in the Ray quadrangle, fine-grained rock with small hornblende phenocrysts occurs as a marginal facies of quartz diorite porphyry dikes. On the other hand, in several places in the part of the Christmas area occupied by Cretaceous strata there are masses of similar gray hornblende porphyry which

a Ransome, F. L., The copper deposits of Ray and Miami, Ariz.: U. S. Geol. Surrey Irof. Paper 115, pp. 65, 66, 1919. 
are rudely stratified and appear to be of effusive origin. It is probable that some of the intrusive gray hornblende porphyry is related to such flows and consequently of Cretaceous age. In several places hornblende porphyry is cut by dikes of quartz-mica diorite.

\section{QUARTZ-HORNBLENDE DIORITE}

The intrusive mass in the northeast cormer of the Christmas area, that near the mouth of Dripping Spring Wash, and the associated clikes are composed of essentially the same kind of rock, a quartz-hornblende diorite. The color of the rock in general is a mottled gray with a greenish cast in weathered specimens. The phenocrysts are nearly white plagioclase, black or green hornblencle and biotite, and quartz. Biotite is subordinate in amount to hornblende, and quartz is only sparingly present. The groundmass is gray, has a fine allotriomorphic texture, and appear's to make up rather less than half the volume of the rock. The feldspar phenocrysts appear to be all plagioclase with zonal growths. 'The average composition is about that of oligoclase. In the groundmass there is also a small amount of alkali feldspar. The rock is thus a porphyritic quartz diorite. As hornblende predominates over biotite in it the word "hornblende" is added to its nause to distinguish it from the somewhat similar rock cropping out farther south, which is called quartz-mica diorite.

The quartz-hornblende diorite is younger than the Cretaceous strata intruded by it and older than the Gila conglomerate, which rests on it in erosional contact. It may, like similar rock in the Ray quadrangle, ${ }^{23}$ be tentatively considered to be of early or middle Tertiny age, more probably the former.

\section{QUARTZ-MICA DIORITE}

The rock composing the intrusive mass at the Christmas mine and the dikes east and south of it shown on Plate I is called quartz-micu diorite. Rocks of this and related types were described by Ransome ${ }^{24}$ under the term quartz diorite porphyry. For convenience the word porphyry, descriptive merely of texture, is omitted, as its use would make the name of the rock too long.

This rock is of predominantly greenish hue in most exposures, but fresh specimens have a mottled gray color. At a distance the dikes appear as nearly white bands. (See Pl. VIII, B.) Phenocrysts of feldspar, biotite, and quartz compose less than half of the volume of the rock. Hornblende is present in some specimens but is nowhere a prominent constituent. The groundmass has a fine to medium 
grained allotriomorphic texture and contains feldspar, quartz, epidote, and in many specimens chlorite, calcite, and other alteration products. The feldspar in both phenocrysts and groundmass is predominantly plagioclase with an average composition about that of oligoclase, but subordinate amounts of alkali feldspar, in part microcline, are present. The average composition of the rock is that of a quartz diorite, although in some of the dikes the proportion of alkali feldspar is nearly sufficient to give the rock the composition of a granodiorite. It can be distinguished from the similar quartzhornblende diorite by the presence of numerous biotite phenocryste and by the somewhat greater abundance of quartz.

This rock, like the quartz-hornblende diorite farther north and similar rocks in the Ray quadrangle, is probably of early Tertiary age. The only direct evidence as to its age is the fact that it cuts Cretaceous strata.

\section{STRUCTURE}

In a broad way the structure of the Christmas area appears to be synclinal. Exposures of Cretaceous rocks in which satisfactory determinations of the attitude of the beds can be made are few and scattered, so that, in general, only the broadest features of the structure can be ascertained. The structure section on Plate I indicates what is known of the structure through the middle of the area. It seems that before faulting introduced complications the Cretaceous strata were bent into a syncline of broadly oval outline occupying most of the area mapped and having an outlet to the east in the narrower and move elongate syncline underlying what is now Reed Basin. The axial plane of the main synclinal basin appears to strike about $\mathrm{N}$. $60^{\circ} \mathrm{E}$. and seems to pass somewhere in the neighborhood of Lee's mine, but the available data are insufficient to establish these inferences with certainty. Eastward the axis swings around and. as Campbell ${ }^{25}$ has shown, the narrower fold under Reed Basin is asymmetric and its axial plane extends approximately along the course of Deer Creek. In the central and south-central parts of the Christmas area the attitude of the strata could not be accurately determined, but it is believed that most of the beds are very gently inclined. A number of the quartz diorite dikes lie near the inferred position of the synclinal axis, and the average trend of the dikes is approximately parallel to the assumed strike of the axis. Tornado limestone rises from under the Cretaceous rocks in the northeast, southeast, and southwest corners of the area. The limestone seems to have been folded concomitantly with the Cretaceous rocks and probably underlies them throughout. The fact that the beds of the

${ }_{25}$ Campbell, M. R., The Deer Creek coal field, Ariz. : U. S. Geol. Survey Bull. 225, 1904. 
two formations lie so nearly parallel to each other in most localities where the contact is exposed, both in the Christmas area and the region east of it, would seem to indicate that there had been little: structural disturbance of the Tornado limestone before the Cretaceous strata were laid down. However, there appears to be an angular unconformity in the sontheast corner of the area, and Campbell ${ }^{20}$ : reports one in Reed Basin, so that there must have been some disturbance of the limestone before Upper Cretaceous time. In view of the structural history of the region in which the Christmas area is situated and the apparent slight extent of the angular unconformities, it is probable that the movements prior to Upper Cretaceous time consisted largely of faulting. It is impossible to judge to what extent the buried parts of the Paleozoic rocks may have been broken by faulting at this time. The pebbles of old rocks in the Cretaceous conglomerates suggest the possibility that such rocks may have been exposed in the Christmas area at the time of their formation, but it is equally possible that these pebbles were derived from distant sources. In the southwest corner of the area the Tornado limestone dipping out from under the Cretaceous rocks is bent into a number of small folds and broken by small faults in addition to the general northeastward tilting of the strata. (See Pl. IX, A.)

The Cretaceous rocks are broken by normal faults. The longest: zone of faulting that has been mapped is the one which has been called the Christmas fault at the mine of that name. This fault starts in the Ray quadrangle northwest of the Christmas mine and bounds the block of Tornado limestone containing the ore bodies of the mine on the northeast. What appears to be a continuation of the same zone of fracturing can be traced by means of limestone blocks southeastward into the Winkelman quadrangle in sec. 15, T. 5 S., R. 16 E. One such block is shown in Plate IX, $B$. The average strike is about $\mathrm{N} .25^{\circ} \mathrm{W}$. At Christmas the relative downthrow is on the east side, but farther south it appears to be reversed. Faulting was not traced continuously in the areas between the blocks of limestone, because of the absence of distinctive beds by means of which displacement could be detected, but it is thought probable that there is an essentially continuous zone of faulting. If so, the zone has a minimum length of about $71 / 2$ miles. In the part of the area where the Cretaceous rocks are the only stratified rocks exposed there are certainly some faults and may be many. The reins of the Saddle Mountain district follow fractures whose strikes vary within rather wide limits. The average strike of the veins is

26 Campbell, M. R., op. cit., p. 245. 
roughly parallel to the average strike of the quartz diorite dikesthat is, about $\mathrm{N}$. $60^{\circ} \mathrm{E}$., nearly at right angles to the strike of the Christmas fault. The dikes may also occupy fault fissures. Slickensided surfaces on outcropping masses of andesitic rocks attest the presence of faults not marked by either veins or dikes. There may well be other faults of which no direct evidence was found. The apparent large thickness of andesitic strata in the vicinity of Lee Mountain may be the result of repetition by faulting.

The Tertiary beds in the northern part of the area are broken by numerous faults. Some of these have been mapped, but there are doubtless many others. In the area between Little Ash Creek and Rock Creek are a number of separate exposures of rhyolite at different altitudes. It is probable that these are remnants of a once continuous lava sheet and that their present separation has been brought about in large measure by faulting, aided, of course, by subsequent erosion. The faulting here continued long enough to involve the Gila conglomerate. The strikes of the faults mapped vary markedly. The throw is of the order of several hundred feet in some places. The close alinement of Dripping Spring Wash, Rock Creek, and the stretch of Gila River between the mouths of these streams doubtless has structural significance. Ransome ${ }^{27}$ has suggested that the portion of the Dripping Spring Range in the Ray quadrangle may be structurally a homoclinal block tilted to the southwest and shattered by numerous later faults, many of which he has mapped. On this hypothesis, which as he has shown fits the known facts better than any other that has been proposed, there is a fault zone buried under the Gila formation in Dripping Spring $V$ alley, and the origin of the valley is directly related to the displacement along this zone. The same line of faults probably continues southeastward across the Christmas area, and the depressions now occupied by Rock Creek and the stretch of Gila River mentioned have resulted primarily from it. The Tertiary beds underlying The Tablelands were not shattered into such small blocks as those farther north. In the portion of The Tablelands included in the Christmas area there is evidence of nothing more than minor dislocations. The rocks have, however, been tilted a few degrees from the horizontal by a series of successive earth movements. as is proved by the angular unconformities between the rocks of different types.

\section{GEOLOGIC HISTORY}

The early geologic history of the Christmas area must be inferred from rocks that crop out in adjoining regions, for none older than

n Ransome, F. L., The copper deposits of Ray and Miami, Ariz.: U. S. Geol. Survey Prof. Paper 115, pp. 81-84, 1919. 
Carboniferous are exposed in this area. As Ransome ${ }^{28}$ has shown, the Pinal schist records a period of marine sedimentation followed by folding; compression, and metamorphism of the sedimentary beds, all of which appears to have taken place long before the close of pre-Cambrian time. The Pinal schist was later intruded by igneous rocks of various types. At the end of the period of plutonic activity the region, according to Ransome, was mountainous and was being attacked by active erosion, which eventually wore it down to a peneplain. One more event in pre-Cambrian time may be indicated by the beds of metamorphosed sandstone unconformably below the quartzites correlated with the Apache group on Ash Creek south of the southeast corner of the Christmas area. 'This rock is well bedded and, although containing much mica of metamorphic origin, is not nearly as schistose as the rock underlying it, which is believed to belong to the Pinal schist. The sandstone may represent deposits formed during an incursion of the sea long after that during which were deposited the beds that later became the Pinal schist, but still in pre-Cambrian time.

Ransome ${ }^{29}$ considers that a large part of the quartzite and conglomerate of the Apache group in the Ray quadrangle was deposited in deltas, but that the Mescal limestone, near the middle of the Apache section in that region, is of marine origin. The crossbedding in the quartzite on Ash Creek indicates the play of shifting currents during its formation, and the ripple marks so beautifully preserved on some of the beds in the upper part of the section show that these beds were laid down in currents and under shallow water. The scanty fossils found in the upper beds are of marme origin. The Mescal limestone is absent, but its place in the section appears to be occupied by thin-banded green shale and red quirtzite. That the rocks of the Apache (?) group exposed in Asll Creek were formed in Cambrian time, from sediment dumped by rivers in the shallow sea water at their mouths, appears to be proved by the discovery of Upper Cambrian fossils near the top of the rocks correlated with the Troy quartzite.

No rocks of Ordovician or Silurian age have yet been recognized in the region adjoining the Christmas area, and the events of those periods are consequently unknown. The Martin limestone, which contains Devonian fossils in its upper part, is of marine origin. This formation has been recognized west ${ }^{30}$ and east ${ }^{31}$ of the Christmas area, and there is shale which may be its equivalent in Ash Creek

${ }^{28}$ Ransome, F. L., op. cit., p. 84.

20 Idem, pp. 85-86.

${ }^{30}$ Idem, pp. $45-46$.

at Ross, C. P., 'The geology and ore dejosits of the Aravaina and Stanley mining districts, Graham County, Ariz.: U. S. Geol. Survey Bull. 763, 1925. 
on the south, so that it is probable that the Christmas area was covered by the sea in Devonian time. In Mississippian and Pennsylvanian time thick deposits of limestone were formed.

No deposits representing Permian or early Mesozoic time are known in this area, which may have been above sea level during this long interval. In the Globe-Ray region extensive faulting and intrusion of diabase occurred at some time in the Mesozoic era, and Ransome ${ }^{32}$ believes that these events may have taken place before the formation of the Cretaceous andesitic strata. No diabase was found in the Christmas area, and no evidence bearing on the age of the diabase was obtained during the present investigation. There was some structural disturbance in the time between the deposition of the Tornado limestone and that of the Cretaceous strata, but the approximate parallelism of the two formations in most places where the contact can be observed would seem to indicate that the amount of disturbance in most parts of the area was small.

In Colorado time there was sufficient relative subsidence of the area to permit the waters of the inland Cretaceous sea to overflow it. The shore of this sea at the time of its greatest westward extent in the region appears to have been near the west border of the Christmas area, as no sedimentary Cretaceous rocks are known beyond this boundary. From the character of the shale and sandstone and of the invertebrate fossils which have been found in them in the region east of the Christmas area ${ }^{33}$ it is evident that they are of marine origin. The coal and conglomerate both indicate that the shore of the sea was close at hand. Perhaps these beds were laid down in a reentrant in the western shore of the Cretaceous sea.

The origin of the coarse conglomerate that consists largely of cobbles of ancient rocks is open to some question. The shape of the cobbles is such as may have resulted from abrasion in streams, but they are so poorly sorted and in part so ill rounded and so large that they can hardly have been transported far by water. There are a number of conceivable sources for the material of the conglomerate, but from the data available it is difficult to visualize such conditions in Colorado time at any place near by as would make it a suitable and probable source for the material. In the northern half of the Christmas quadrangle quartzite of the Apache group and preCambrian granite are now exposed in abundance. ${ }^{34}$ The Mescal Range now constitutes a formidable barrier, cut only by the narrow canyon of Gila River, to southward transportation of material from this part of the quadrangle. These ridges may not have existed in

$a$ Ransome, F. L., op. cit., p. 87

${ }^{33}$ Ross, C. P., op. cit.

34 Darton, N. H., personal communication. $31463-25-3$ 
Colorado time, and if so, material to form the conglomerate might have been brought southward, provided the ancient rocks were then exposed. It would seem that, if the movement in which the Mescal Range was uplifted and the consequent erosion had not yet taken place, then the ancient rocks would still have been covered by later Paleozoic strata. In view of the present distribution of the Cretaceous rocks and the geologic history of the Globe-Ray region, ${ }^{35}$ it seems more probable that sufficient movement had already taken place to initiate the formation of the Mescal Range and that the depression south of the range had been outlined before the deposition of the Cretaceous strata that now occupy it. On the assumption that the production of the dominant structural forms of the present day had already been begun and that consequently the broad features of the present topography had been blocked out, the cobbles of the Cretaceous conglomerate may have been transported by ancestors of Gila River and Dripping Spring Wash, emptying into an arm of the Cretaceous sea. It is conceivable that part of the material may have been derived from masses of ancient rocks then exposed and now covered by the Cretaceous deposits, but there is no direct evidence to confirm this hypothesis. The probable physiographic conditions in Colorado time, together with the lack of evidence of any such structural disturbance as would have been required to cause such ancient rocks to crop out in this part of the area in Colorado time, render the hypothesis unlikely. The andesitic material in the matrix of the coarse conglomerate and the subangular andesitic pebbles, mostly a few inches wide, that make up the greater part of some conglomerate beds were undoubtedly derived by erosion of volcanic beds formed earlier in the same period. If the cobbles of the coarse conglomerate were brought down by streams, as suggested, it would seem that the streams must have had steep gradients and that many of the cobbles were transported for rather short distances in them. It would be possible for such conglomerate to be formed by the reworking of beds of coarse alluvial material, but the original source of this material would be equally undeterminable. Another possibility may be suggested. If glaciers existed in this region in Colorado time, conglomerate beds of the sort described might well have been derived from the till formed by them with only a small amount of transportation or sorting in running water. A glacier might transport débris far from its source without much rounding of the edges of the component fragments.

Whatever the origin of the Cretaceous sedimentary beds, it is evident that volcanism was the dominant factor in the formation of the Cretaceous succession. Great masses of material, largely of

${ }^{35}$ Ransome, F. L., op. cit., pp. 84-89. 
andesitic composition, were ejected from vents whose location is unknown. Many of the eruptions took place with explosive violence, but quiet outflows of lava also played an important part. The rolcanic beds are traversed by numerous porphyritic intrusive masses, principally dikes. Many of the dikes are of similar composition to the volcanic beds and doubtless are related to them. Some of these may mark conduits through which lava was ejected.

After the deposition of the Cretaceous rocks they and the rocks below them were relatively uplifted to a position well above sea level and folded. In the Christmas area the principal folding in the Cretaceous beds preceded the deposition of the Tertiary strata. This does not accord with the record in the Stanley district, only a few miles to the east, where strata of both ages are sharply tilted but along the contact are essentially parallel to each other.

The folding was succeeded by faulting, which continued, probably intermittently, throughout the Tertiary period and may have extended into the Quaternary. Indeed, there are indications in the general region in which the _Christmas area lies that fault movements have continued up to the present time. It seems that since some time in the Mesozoic era the earth's crust in this region has not been in stable equilibrium. The adjustments necessitated have been made largely by fracturing and slipping of the rock masses along the fractures. In the Christmas area there has been extensire folding, and in neighboring regions evidence of folding can be seen in many places, but in nearly all it is of minor importance. The process of adjustment has continued up to the present time by a series of movements of diminishing violence. The igneous activity, both intrusive and extrusive, which has been manifested at various times must be intimately related to the readjustment. The movements of magna may have in part produced the necessity for readjustment in the crustal rocks and in part resulted from the movements of those rocks. If the mass of quartz-hornblende diorite in the Mescal Range is a laccolith, as it appears to be, its intrusion doubtless contributed to the uplift of the overlying rocks. The part played by the dikes and irregular intrusive masses is less clear. All the intrusive rocks in the Christmas area, except those connected with the Cretaccous volcanism already mentioned, appear to be of Tertiary age. The granular rocks were intruded early in the Tertiary period, and the fine-grained rocks connected with the Tertiary volcanism probably came later. In any particular area the periods of crustal movement were probably separated by periods of quiescence, and it may well be that the disturbances were of local rather than general effect. Thus in the Christmas area there were strong crustal disturbances after the formation of the Cretaceous 
beds and before the deposition of the earliest known Tertiary strata, whereas less than 10 miles farther east, in the Aravaipa-Stanley region, there is little evidence of structural movements in the corresponding interval. There can be little doubt that the rocks of both formations in the two areas are essentially contemporaneous.

The resultant effect of the earth movements subsequent to the Cretaceous volcanism probably was to uplift the region and increase its relief. Erosion, thus accelerated, continued long enough to subdue the relief to a notable degree. The present remnants of the earliest Tertiary strata were laid down on nearly level surfaces, but in the intervening areas in which no Tertiary beds now remain there were doubtless hills. The summits of the Mescal Range may never have been covered by Tertiary strata, and the same may perhaps be true of such heights as Lee Mountain. The great similarity between the conglomerate at the base of the Tertiary sequence and the Gila conglomerate implies similarity in the conditions prevailing at the time of deposition. This means that erosion was still active and that the climate was not very different from that of to-day, although it may have been more humid. The deposition of the conglomerate was followed successively by the eruption of basaltic lava, the deposition of siliceous tuff and tuffaceous agglomerate, and the outflow of rhyolitic lava similar in composition to the fragments in the agglomerate. There are slight unconformities between these deposits which appear to indicate that earth movements were in progress during the period of volcanism.

After the eruptions ceased normal faulting was resumed, and there was probably sufficient uplift to accelerate erosion once more. Large quantities of the Tertiary lava and associated sedimentary beds were swept away. The major features of the resulting topography were probably in many respects similar to those of the present day. Near the end of the Tertiary period came the deposition of the Gila conglomerate. This formation is found at present in the Christmas area only in the valleys of Dripping Spring Wash and Rock Creek. It resulted from the deposition in stream valleys of excess loads of sediment brought down from points farther upstream, and consequently it probably never formed a blanket over the whole area, but its distribution was probably once more extensive than at present. Later came further faulting, in which blocks of the Gila were thrown down against the edges of blocks of older Tertiary lava. These movements probably came early in the Pleistocene epoch. A little later, perhaps accelerated by the movements just mentioned, erosion became sufficiently powerful to cut deep gulches and sweep away much of the Gila formation. Subsequent fluctuations in the erosive power of the Quaternary streams are recorded by alluvial deposits 
of at least two ages, which might be accounted for either by climatic changes or by earth movements. There is an increasing volume of evidence that climatic changes have occurred since the late Pliocene. The fossils in beds of that age in San Pedro Valley, ${ }^{36}$ south of the Christmas area, seem to show that the climate when these beds were deposited was more humid than at present. The testimony of old residents shows that there have been marked changes in vegetation in the last 40 years. On the other hand, as Ransome ${ }^{37}$ has shown, the character of the Gila formation in the mountains is such as could have resulted from streams acting uncer conditions similar to those of the present, and the recent changes in vegetation are in part to be accounted for by the influences of human industry. From the data now available it can not be said that the climate at any time since the late Tertiary has differed markedly from that of the present, although some changes doubtless have taken place.

\section{ORE DEPOSITS}

\section{HISTORY AND PRODUCTION}

A large part of the ore deposits of the Saddle Mountain and Ban. ner districts have been known and intermittently worked since the seventies, but little ore was shipped before the beginning of the present century. None of the mines were ever developed sufficiently to attain steady and profitable production for more than a few years at a time, and not many of them have been profitably operated for more than a few consecutive months. Ore of good grade has been found in numerous places, however, and in some of the deposits there may be large quantities of ore of commercial grade still unmined. From available estimates of the production of the mines and prospects visited it appears that over 550,000 tons of copper ore, about 6,500 tons of lead-silver ore, and a little zinc ore have been shipped from them. Gold ore of a total value of some tens of thousands of dollars has been shipped from a few mines. Vanadium ore has been mined in two or three places, and a little may have been shipped. Except for some small pockets of high-grade gold ore, the ores of the several metals mined have been of moderate tenor. Most of the copper ore contains from 2 to 4 per cent of copper, but there are small bodies of notably higher grade. Probably most of the lead-silver ore mined contained less than 40 ounces of silver to the ton, although some ore assaying as much as 250 ounces to the ton has been found. Some of the gold ore found near the surface was very rich, but most of the deposits do not contain large amounts of this metal.

${ }^{36}$ Gidley, J. W., op. cit., p. 121.

a Ransome, F. L., op. cit., pp. 71-74. 


\section{CLAIMI BOUNDARIES}

The property map (PI. X) shows all the mines and prospects in the two districts regarding which any information was obtained. The position and extent of the claim groups whose outlines are drawn in full lines are fairly accurately known. The dashed lines show in a general way the position and extent of the land comprised in the respective groups but are not at all accurate in detail. For a number of claims the data obtained are insufficient on which to draw even approximate boundaries. The position of these claims is indicated by the names supplemented where possible by symbols showing the location of the principal workings. It is probable that there are a few prospects regarding which no information is available and which are consequently not shown on the map. The boundaries of the Banner mining district are believed to be correctly shown, being based on data supplied by D. W. O'Carroll, one of those who originally set the limits of the district. Exact data regarding the boundaries of the Saddle Mountain district were not obtained. Those drawn on Plate $\mathrm{X}$ are believed to be roughly correct. although it is possible that the southern boundary should be moved south a short distance to include prospects reported to be situated near Biddick's cabin on Ash Creek. No ore deposits are known for considerable distances east and north of the limits of the Saddle Mountain district indicated on Plate X.

\section{LEAD-SILVER VEINS}

The deposits grouped under the term lead-silver veins have a gangue consisting essentially of quartz, barite, and calcite and contain galena and other sulphides. Ore bodies of this type are known only in the Saddle Mountain district, and most of them are north of Old Mill, between Ash Creek and Deer Creek. Most of the known veins are on the Adjust, Saddle Mountain, and Little Treasure properties and on the claims of J. N. Carmichael and J. W. Lee, which lie in this vicinity.

The country rock is Cretaceous andesite of various types, principally of effusive origin, cut by several dikes of quartz-mica diorite. The deposits lie principally in the volcanic rocks but also cut the diorite in places. They have been formed along zones of strong shearing and brecciation, partly by replacement of the rock, partly by filling of openings with vein matter. In most of the veins there is a central portion from a few inches to perhaps 2 feet wide of vein matter with only a minor amount of material derived from the original rock. The rein matter in most exposures is banded, with altered rock material between many of the bands ranging in width from a thin film up to several inches. In 
many places the banding is obscured by brecciation, and the vein is composed of a heterogeneous collection of angular fragments of vein matter and altered rock. In a few places the veins contain openings lined with crystals. After mineralization was well under way there was renewed movement, resulting in brecciation of the vein matter. The zone of intense mineralization is flanked on both sides by sheared country rock, more or less thoroughly altered and replaced and in some exposures interleaved with bands of vein matter. Next beyond are zones in which the rock is not greatly sheared but is altered and contains small amounts of pyrite and other products of mineralization. The transition between this material and the mineralized country rock is gradual. In most places there are fairly well defined walls between which the more intensely mineralized parts of the vein are confined. The walls show slickensides and in some places are lined with gouge. The width between walls is in places as much as 7 feet but in most exposures is less than half that. The strike of the veins ranges from east to $\mathrm{N}$. $35^{\circ} \mathrm{E}$, the average is about $\mathrm{N}$. $70^{\circ} \mathrm{E}$. The dips range from $60^{\circ}$ to $90^{\circ}$, and dips to the north and south are about equally common. The veins weather more easily than the surrounding andesite, and their outcrops are consequently inconspicuous, as can be seen from Plate XI, $A$. Vegetation grows a little more freely on the mineralized outcrops than elsewhere, and some of the veins can be traced on the surface by means of the lines of bushes along them, but this is at best a vague and unsatisfactory guide. At a number of places the veins are known to branch, and there can be little doubt that in general they form a linked system. Some idea of . the attitucle of the better-developed veins can be gained from the strikes and dips plotted on Plate I. A number of other veins are known to exist.

The nonmetallic minerals of the veins are quartz, barite, and calcite, with gypsum in the oxidized parts. The country rock associated with them contains sericite, chlorite, quartz, and calcite, developerl in large part during the mineralization. The hypogene sulphides are galena, sphalerite, pyrite, and chalcopyrite. Chalcopyrite is nowhere abundant, and much of the ore does not contain it. Much of the pyrite is in the marginal parts of the veins and disseminated in the wall rock. The pyrite is the latest and galena the earliest of the hypogene sulphides to form. Quartz crystallized in two generations. The silver, which is the metal of principal economic importance, appears to be associated with all three of the common sulphides but is probably most abundant in the galena. In some specimens of galena tiny bright blebs are visible under the microscope, and these are probably a silver mineral. No other hypogene silver minerals are known, and the silver content of the ore can be 
learned only by assay. There is a little gold in all the ore, and rich gold ore is reported to have been found in the early days. Indeed, it was the discovery of a gold nugget near the head of Little Gold Gulch by a member of a scouting expedition from old Camp Grant about 1880 that first drew attention to these veins. ${ }^{38}$

Most of the veins have been more or less oxidized at the surface, but in many outcrops there is residual hypogene sulphide. The depth to which oxidation has reached ranges from a few feet to perhaps as much as 40 feet. The oxidized metallic minerals known are cerusite, anglesite, limonite, and kindred iron oxides, and small amounts of chrysocolla. Gypsum is a prominent constituent of the oxidized parts of the ore bodies, occurring as flakes on the walls, in irregular masses, and in veinlets. Some of the veinlets are closely spaced and approximately parallel, producing a banded appearance like that of the original ore. Much of the oxidized ore is ironstained material that shows little evidence of the presence of valuable metals yet may yield as much as 100 ounces of silver to the ton. Supergene silver minerals were distinguished only in ore from the Little Treasure mine. This ore contains wire silver partly filling small cavities and probably also argentite and pyargyrite. In some of the veins the supergene copper sulphides chalcocite, covellite, and bornite are present, but the copper enrichment is too slight to be of much commercial importance in any of the ore so far discovered.

\section{PYRITIC GOLD DEPOSITS}

The deposits in which pyrite is the characteristic sulphide and gold the metal of principal economic importance may be termed the pyritic gold deposits. The deposits in the vicinity of the lower part of Ash Creek are of this character. They include those on the Hoosier group, the prospects held by Reider and his various partners, Cook \& Piper, R. F. Cook, Charles Courtney, part of the claims of J. N. Carmichael, and those of the Two Queens and Pool mines. Some of J. W. Lee's claims may be on bodies of this character. The deposits on the Hogvall prospect, near Chilito, and those on Mellor's prospects, near Christmas, also resemble this type.

The deposits lie in shear zones, which so far as known strike somewhat north of east and dip very steeply. They are principally in Cretaceous volcanic rocks. Some are in apparently intrusive hornblende porphyry. There are dikes of quartz-mica diorite near most of them, and such rock has been sheared and mineralized in places. The Hogvall prospect, which may be of this class, is in the Martin limestone. Part of the mineralized rock on the Hoosier

${ }^{88}$ Chittenđen, G. B., letter dated October 10, 1922. 


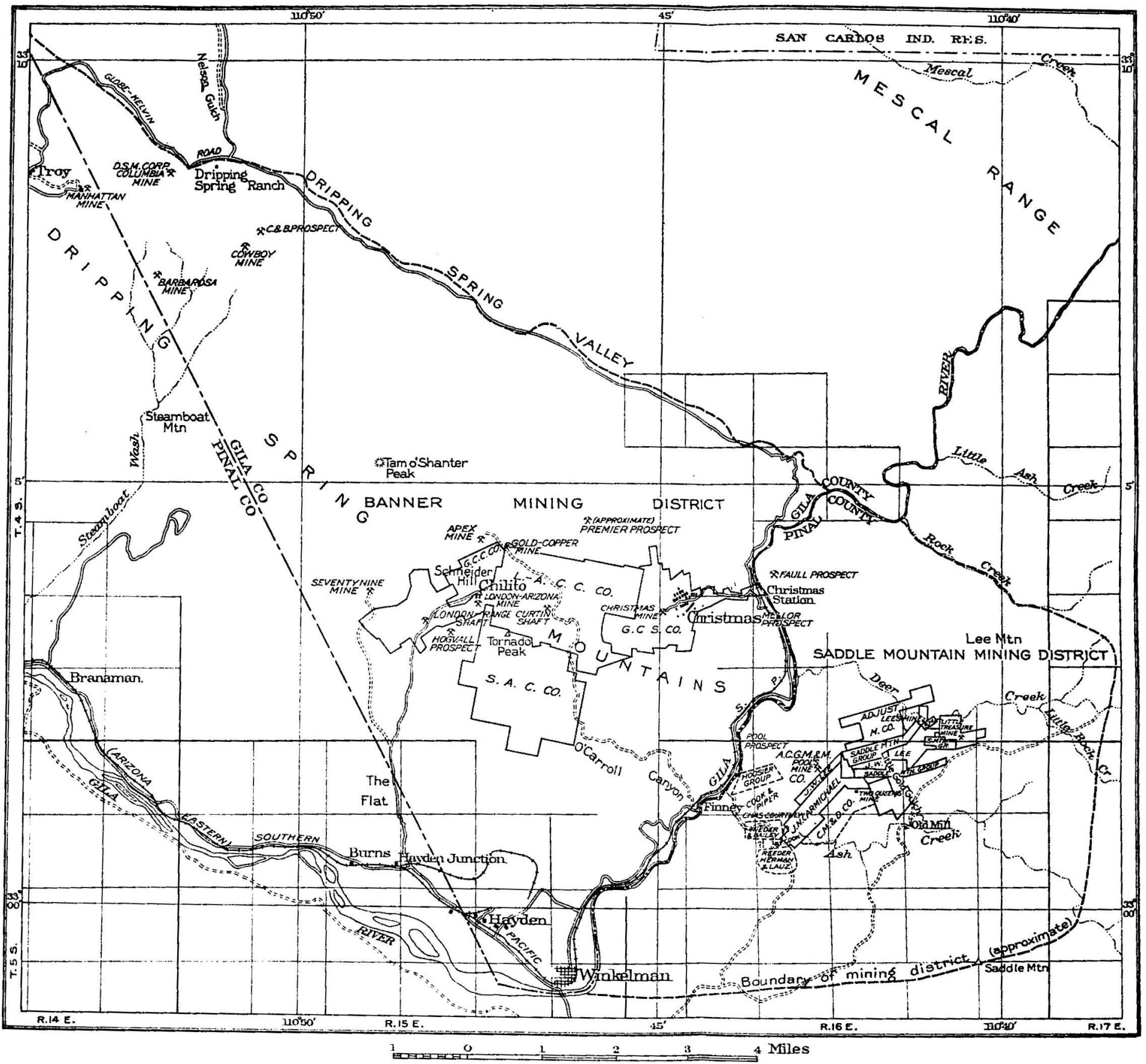

PROPERTY MAP OF THE SADDLE MOUNTAIN AND BANNER MINING DISTRICTS 



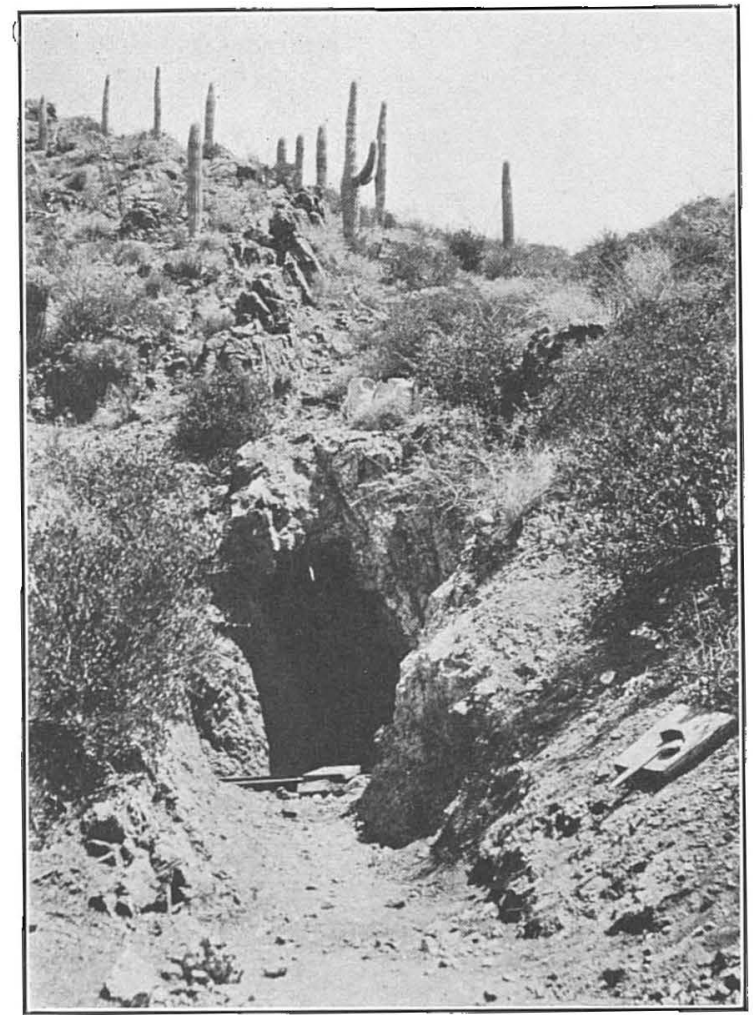

A. OUTCROP OF BIG ROGK VEIN ON SADDLE MOUNTAIN GROUP

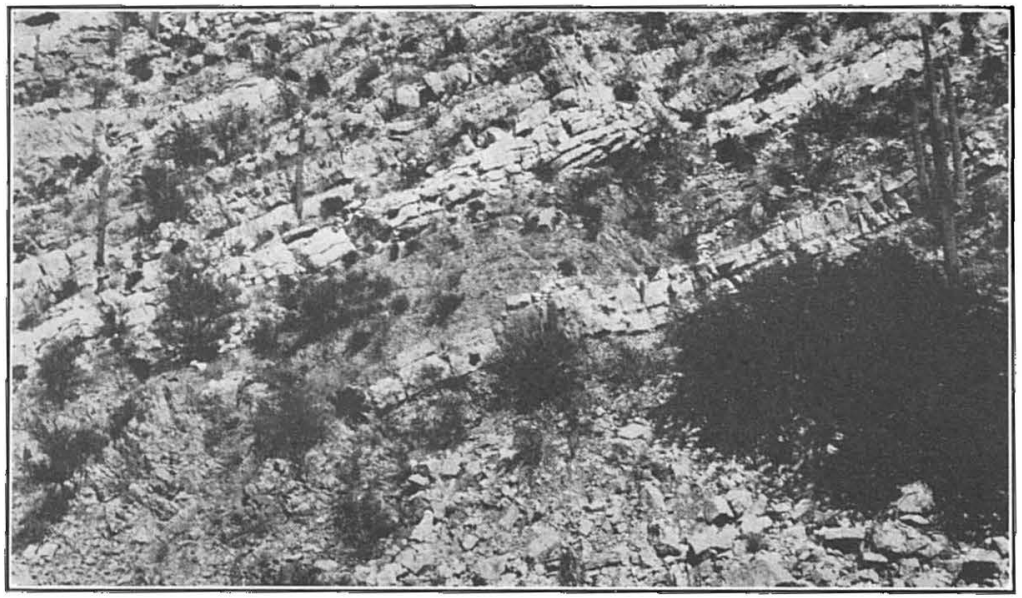

B. SILL OF ALTERED TRAP IN TORNADO LIMESTONE ON GILA RIVER JUST SOUTH OF THE SOUTHERN BORDER OF THE CHRISTMAS AREA 

group is in the Tornado limestone. Cretaceous sedimentary strata lie close to a few of the deposits.

The rocks along the mineralized zones are sheared and brecciated, and chlorite, sericite, calcite, and quartz have been developed in them. Pyrite is present wherever it has not been destroyed by oxidation, and in numerous places it is accompanied by chalcopyrite. Magnetite and specularite are prominent in the ore in limestone on the Hoonsier group and were also noted in some of Reider's specimens. Metallic gold can be panned from some of the specimens of oxidized rock, and the rock containing pyrite also carries gold. Much of the unoxidized ore is reported to carry $\$ 5$ to $\$ 15$ worth of gold to the ton, although considerably higher assays have been obtained from small bodies. Some of the oxidized parts of the zones carry larger proportions of gold, and high assays have been obtained on samples of such ore. There is sufficient copper in some of the ore to be of commercial value, assays as high as 10 per cent of copper being reported. These mineralized bodies have been formed principally by metasomatic alteration of the rocks along paths opened by shearing. The replacement of the rocks was accompanied by the filling of crevices by quartz and minor amounts of other minerals.

Oxidation is irregular and in most places does not extend very deep. On the Hoosier group it goes down less than 50 feet. From the scanty information available it seems that it may reach greater depths on the Reider \& Bailey group and at the Two Queens mine. In most of the outcrops oxidation has been thorough and the sulphide minerals are completely destroyed. Gold has been concentrated in favorable parts of the oxidized ore bodies, probably in the main by the leaching out of more soluble constituents. Much of the oxidized material is stained with copper.

\section{DISSEMINATED PYRITE DEPOSITS}

In a few.places pyrite crystals are disseminated in rock where no definite shear zones are present. These deposits may be merely variations of the pyritic gold deposits on shear zones just described. In this class may be grouped some of the deposits on Little Gold Gulch, on the Faull claims on Gila River, and a quarter of a mile east of the old Christmas workings. The rocks in which the pyrite occurs are basalt and dark andesite of Cretaceous age. Some of the rock on Little Gold Gulch is reticulated with narrow quartz veinlets, and on the east side of the gulch are shear zones which have been prospected for gold.

On Little Gold Gulch below the pyritic deposits and near Christmas in the rock containing disseminated pyrite there are prominent 
outcrops of white gypsum filling joint cracks and extending beyond in masses of nearly pure gypsum. (See Pl. XII, A.) The mode of formation of these deposits and their relation, if any, to the bodies of disseminated pyrite near by are not known. There is plenty of sulphur, both as sulphide and as sulphate, deposited by hypogene solutions in neighboring ore bodies and calcium is widespread in the rocks of the region. The gypsum of these two cleposits may have been precipitated from water of the vadose circulation that had derived its sulphate content from oxidizing sulphides, or from ascending solutions related to those which produced the ore bodies, or from an intermingling of such solutions and descending meteoric water.

\section{CONTACT-METAMORPHIC DEPOSITS}

The ore bodies described under the term contact-metamorphic deposits are replacement masses, largely in limestone, which owe their origin to emanations from near-by intrusive rocks. Most of them contain garnet and other characteristic contact-metamorphic minerals. In others such minerals were not found, but the deposits are otherwise so similar to the more typical contact-metamorphic deposits that it seems best to group them together. The deposits thus grouped include those of the Christmas mine, the LondonArizona properties, the Schneider group, and the Gold-Copper, Seventy-nine, Apex, and Columbia mines. The deposits of the Cowboy mine and the C. \& B. and Premier prospects may also be related to this group. The deposits on the Scottish American Copper Co.'s property south of the London-Arizona claims are presumably similar, but this company was not operating at the time of visit and so far as could be learned had not done much development work. A large part are in the Tornado limestone, but there are also extensive replacement deposits in the Martin limestone, some in the Troy quartzite, and related deposits in the Mescal limestone and in diabase.

The deposits of this group show greater diversity than those previously described, partly because of original differences in the country rock and partly because of variations in the proportions of the minerals present. Some of the deposits are largely confined to certain limestone beds, others are of irregular outline, and still others are of veinlike form on shear zones. All these variations are due principally to differences in the effect of mineralization on different kinds of rock under what appear to be in other respects fundamentally similar conditions. Some of the deposits are mined for copper; others are mined for lead and silver, or for lead and gold. Parts of some deposits have been mined for the zinc contained, and oxidized portions of a few have been prospected for vanadium. All the deposits were formed by replacement, rather than by the 
filling of open spaces, all lie near dikes or similar masses of quartzmica diorite, and nearly all are known to contain typical contactmetamorphic silicate minerals. The evídence seems clear that most of the deposits on the properties mentioned above were formed by emanations that had their source in the quartz-mica diorite magma and that interacted with susceptible parts of the rocks in contact with the intrusions, forming replacement masses, parts of which contain sufficient quantities of metallic minerals to constitute ore. The diorite near the deposits is itself altered, and apparently a part of the mineralizing emanations welled up through it from the magma until they encountered conditions favorable for spreading out into the inclosing rocks. The alteration in the diorite consists in sericitization and the introduction of pyrite and quartz.

'The shape and location of the ore bodies in limestone appear to be controlled in general by the shape. size, and position of the dioritic mass that was the source of mineralization, the character and position of fractures or shear zones in the limestone, and the size and position of beds susceptible of replacement. At some places, as at the Christmas mine, the ore bodies appear to follow the intrusive contacts rather closely. Elsewhere, especially where the dioritic masses exposed are small, the ores are farther from the contact. Most of the deposits afford evidence that the entrance of the mineralizing material was facilitated by fracturing of the rock, and the deposits are more or less localized along such fracture zones. In some places the existence of the fractures can only be inferred from the elongation of the ore bodies in certain directions. Elsewhere evidence of shearing and brecciation can be clearly seen. The places where premineral fracturing can now be discovered are in general those where replacement of the rock has not extended far beyond the fracture zones, and in a number of such places contact-metamorphic minerals were not observed. The fractures and shear zones, both inferred and observed, have steep dips and strike nearly east, many of them somewhat north of east. although there is considerable local variation. The average strike of the fractures thus corresponds to the average strike of the quartz-mica diorite dikes as shown on Plates I and XVI, and the fracturing may be related to the intrusion of the diorite and have taken place at the same time or just prior to the intrusion. At each of the deposits in limestone certain of the beds are more thoroughly replaced than others, and only fractions of the replaced portions are of value as ore. This probably results in part from original differences in composition and in permeability. At the Christmas mine, in the Tornado limestone, the comparatively pure and coarsergrained beds are more thoroughly replaced by ore minerals than the finer-grained rocks with a lower carbonate content, although the 
latter are also greatly altered. Such obvious differences in lithologic character do not, however, account for some of the differences noted, as is strikingly illustrated by the bed locally known as the O'Carroll ore bed, near the base of the Martin limestone. Mineralized rock at this horizon occurs at a number of places on a line of outcrop about a mile east of Chilito, but there is little evidence of mineralization at other horizons in the formation where the original lithologic character would seem to have been similar. It is possible that this difference may be partly accounted for by the relations between the limestone and the intrusive rock. The diorite masses that presumably caused most of the contact metamorphism in this vicinity now crop out west of the O'Carroll ore bed and at lower altitudes, and the upper parts, now eroded, may never have reached much above that bed. There are, however, a number of smaller masses of similar diorite that did reach high enough to cut the Martin limestone above this horizon. The lateral limits of the replacement bodies are conceived to have been determined in each place largely by the distance the emanations traveled along a particular bed from the point of access to the point where chemical interaction ceased because of exhaustion of the emanation. The point of exhaustion was in turn dependent on the quantity, character, and physical condition of the material given off by the intrusive magma, and on the readiness with which it was able to react with and permeate the limestone. The points of access were apparently along the contact of the more replaceable bed with an intrusive body of quartz-mica diorite and along fracture zones that cut the bed. The valuable sulphides were in the main localized along the fracture zones and not at the intrusive contact. In the simplest case ore bodies produced as suggested above would have the form of elliptical disks with rounded edges, bounded above and below by beds of shale or other difficultly replaceable material. Between different ore bodies in a single bed and between the ore bodies and the intrusive mass the limestone would be more or less thoroughly replaced by minerals other than the valuable sulphides. As a matter of fact such a shape is never more than approximated, and some of the ore bodies are most irregular in form. The irregularities have resulted from the numerous possible variations in the character and condition of the bed affected, the emanations, the fractures, and the intrusive, as well as from interference between the emanations circulating from neighboring points of access to the same bed. At a number of places there are several beds which proved susceptible of replacement by ore minerals, and as a consequence more or less separate ore bodies have been formed one above another, separated by altered but valueless material. Some complexities resulting from postmineral faulting have been super- 
imposed on the original irregularities, but so far as known these are of minor importance.

The minerals resulting from the contact metamorphism in limestone include quartz, two varieties of andradite garnet, vesuvianite, wollastonite, epidote, pargasite or a similar amphibole, chlorite, fluorite, chalcedony, magnetite, specularite, chalcopyrite, pyrite, sphalerite, galena, and perhaps bornite. Calcite has been recrystallized and redistributed. All these minerals, except fluorite, have been found in the Christmas mine. Most of the other deposits are known to contain some of the silicates mentioned, and more of these as well as other minerals as yet unknown in the region will probably be discovered in the course of future development and study. Many of the deposits in limestone visited contain most of the metallic sulphides listed above, but the proportions vary widely. Details of the occurrence of the several minerals are given in the mine descriptions (pp. 41-69).

At the Christmas mine and probably also elsewhere the replacement bodies grade, in most places abruptly, into limestone that has been recrystallized into marble but is otherwise little altered. The alteration in the beds between those containing the ore bodies is largely silicification, although most of the minerals mentioned above can be found in such beds in minor amounts, and epidote and chlorite are rather common in them. Many of these beds still show stratification and are plainly of sedimentary origin; these were doubtless shale and impure limestone. In places, according to Locke and Bjorge, there are sills of fine-grained quartz-mica diorite that are difficult to distinguish from metamorphosed shale. The original character of some of the beds between ore bodies can not be determined. In the Tornado limestone exposed along Gila River immediately south of the south boundary of the Christmas area there are fine-grained sills of dark-green trap like that shown in Plate $\mathrm{XI}, B$. Megascopically this rock resembles the diabase that is widely distributed in the Ray quadrangle. Under the microscope it is seen to be altered to an aggregate of quartz, calcite, and indeterminate dark dust. Some of the barren strata in the Christmas mine may be composed of more thoroughly silicified rock of this character.

Little information is available regarding the ore deposits in the Troy quartzite. Ore of good grade has been mined from such rock on Schneider Hill, but the bodies found appear to have been all rather small. It is probable that these ore bodies are replacement deposits similar and closely related genetically to those in limestone just described. The major difference probably is that the quartzite was less favorable for replacement than the limestone, and consequently the ore bodies produced in it were smaller and more irregular. 
The deposits in diabase at the Columbia mine differ somewhat from the other deposits described in this section but are probably related genetically to them. They are replacement deposits along shear zones near intrusive bodies of quartz-mica diorite. Contactmetamorphic minerals have not been found in the diabase, but calcareous shale in another part of the mine contains vesuvianite and garnet, and the mineralization is similar to that of the typical contact-metamorphic deposits.

Oxidation has attacked all the contact-metamorphic deposits of the area, and a large part of the ore mined was oxidized material. In most of the deposits, howerer. residual hypogene sulphides can be found at or near the surface. Oxidation probably nowhere extends more than 100 feet below the surface and in most places less than that. The oxidized minerals include malachite, chrysocolla, azurite, native copper, gold, hydrous manganese oxide, limonite, and kindred iron oxides, copper pitch ore, cerusite, anglesite, plumbojarosite, wulfenite, gypsum, and alunite. Concentration of the oxidized minerals of the valuable metals has taken place to some extent, especially in the lead deposits. The rich gold ore of the Apex and Cowboy mines may have been produced by concentration during oxidation. In both the gold was found in the oxidized part of lead ore bodies, but specimens were not available for examination. Vanadinite has baen found associated with wulfenite in oxidized ore at three places in the Banner district. This mineral was not recognized in any of the deposits visited in the present investigation, but wulfenite is known to have been obtained from two of them. It may well be that the vanadinite was formed by the oxidation of lead deposits similar to those of the Seventynine mine, for example.

Enrichment by supergene sulphides has taken place in all the copper deposits seen but appears to be sporadic. The principal supergene sulphide is chalcocite. A little covellite ras noted. Bornite is present in small veinlets in the ore bodies and might be interpreted as formed either in a late stage of hypogene deposition or early in the production of supergene sulphides, both chalcocite and covellite being later than the bornite. If the bornite is supergene, then enrichment of this character has greatly improved the tenor of the ore at Christmas. Veinlets of chalcocite, almost certainly of supergene origin, penetrate the ore down to at least the 300-foot level, but the amount of enrichment from this source in the ore seen is probably not very large. To judge by the available specimens massive chalcocite was present in the ore of the Schneider Hill deposits and in the tunnels of the London-Arizona mine. These specimens were, however, probably picked from the richer ore, and a considerable part of the ore shipped is believed 
to have been oxidized material without large amounts of sulphides of any kind in it.

\section{GENERALIZATIONS AND INFERENCES}

A number of generalizations and inferences can be drawn from a study of the ore deposits of the Saddle Mountain and Banner districts, and most of them have a direct bearing on economic problems. The following statements are based on all available evidence, but they must be regarded as expressions of opinion rather than of proved facts.

The ore deposits of the two districts have so many points of similarity that they may be confidently regarded as genetically related products of the same period of mineralization. Some are certainly and the others probably not older than the end of the Cretaceous, and all are of types that are generally regarded as genetically related to igneous rocks. The only igneous rocks known in either district whose character and age would permit their consideration in this connection are the quartz-mica diorite and quartz-hornblende diorite, both believed to be of early Tertiary age. Many of the ore deposits are intimately associated with quartz-mica diorite, and nearly all the known deposits have outcrops of this rock near by, whereas the quartz-hornblende diorite is not known to be associated with any of the ore deposits. Thus the same magmatic source from which the quartz-mica diorite came also supplied the agents of mineralization. Although the mineralizing solutions presumably came for the most part from depths below anything yet exposed by erosion, they rose near and in part through masses of quartz-mica diorite which are so exposed, and ore bodies are therefore to be expected only in the vicinity of such masses. Of course, there may be dioritic dikes with associated ore bodies which through the vagaries of erosion do not crop out. A study of the geologic map of the Christmas area (Pl. I) and of that of the Ray quadrangle, reproduced in part in Plate XVI, brings out some features of the distribution of the intrusions. 'In the Saddle Mountain district most of the dikes of quartz-mica diorite are included in an area about 4 miles long and $11 / 2$ miles wide trending about $\mathrm{N}$. $70^{\circ} \mathrm{E}$., which is the average strike of the dikes. The same area includes nearly all the known mineral deposits in the district and all those known to be of any value. In the Banner district the diorite bodies are more scatteréd, more irregular, and on the average larger. Associated with these are contact-metamorphic and similar ore bodies, a number of which are larger than the deposits of the Saddle Mountain district. In the vicinity of Troy, partly in and partly beyond the limits of the Banner district, there is another group of dikes. These lie in an area about 5 miles long by $21 / 2$ miles 
wide, trending about N. $80^{\circ}$ E., which again is about the average strike of the dikes. The Columbia mine and a number of others are in this area. The strikes of the dikes in both groups are fairly consistent within the group but are independent of the direction of the major faults in the region. The dikes and the veins associated with them appear to occupy fissures and shear zones formed subsequently to much of the faulting in the region, although some of the dikes near Troy seem to follow fissures that form parts of the regional fault pattern. The set of fractures now occupied by the dikes and ore deposits was probably produced at an early stage in the structural disturbance in which the quartz-mica diorite was intruded. Where the fractures were closely spaced the diorite magma may have split up into smaller masses than it could elsewhere. Another possibility is that under the areas of closely spaced dikes there are diorite masses larger than any exposed at the surface and that the force of intrusion of these masses caused the production of fractures in the overlying rocks through which narrow apophyses. from the diorite magma were thrust.

As the ore deposits are interrelated, it follows that gradations between them may be expected. It is conceivable that a vein containing no contact-metamorphic minerals might be found to grade into a contact-metamorphic deposit where the conditions were favorable. Typical contact-metamorphic deposits can be formed only in rock susceptible of replacement of that character. In these two districts the rocks known to be suitable for such replacement comprise the purer beds of the Tornado limestone and certain beds in the Martin limestone, especially one near its base. Deposits have also been found in the Troy quartzite and in a rock supposed to belong to the Mescal limestone, but they are of less value. It is probable that valuable contact-metamorphic deposits of any great size will not be found in any of the rocks in the region other than those enumerated above, and that most of the large ore bodies of this type are confined to the Tormado and Martin limestones.

Although all the deposits were produced in the same period of mineralization they were doubtless not all formed simultaneously, and different types were probably formed at slightly different.times. The contact-metamorphic deposits were doubtless produced in general at an early stage. The order of formation of the pyritic deposits, disseminated and in shear zones, and the lead-silver veins is not known. If order of deposition of the minerals in the ore is a criterion, then it would seem that the pyritic deposits are younger than those of galena and sphalerite, but other evidence is lacking.

From the facts above set forth something can be inferred as to future possibilities in the exploitation of specific deposits, and 
examples of such inferences are given below. The Cretaceous strata that form the wall rock of the veins of the Saddle Mountain district are underlain by the Tornado limestone, which is cut by quartz-mica diorite, perhaps by a large mass of this rock. Consequently contactmetamorphic deposits may be expected in the limestone, but it is by no means certain that they lie under the deposits now being worked, which may be underlain by quartz-mica diorite in which there has been little or no valuable mineralization. Before passing out of the Cretaceous rocks the lead-silver veins may grade into pyritic deposits in depth, or the reverse may be true, according to which is the older. At the Christmas mine the bottom of the No. 3 shaft is probably less than 200 feet above the lower limit at which valuable ore bodies are to be expected, but on the downthrown side of the Christmas fault limestone lithologically favorable to the production of ore bodies extends to much greater depths and has not yet been explored.

\section{MINES AND PROSPECTS}

\section{ADJUST MINE}

Location.-The Adjust mine, owned by the Adjust Mining Co., is on the south side of Deer Creek in secs. 34 and 35, T. 4 S., R. 16 E., about $21 / 2$ miles by trail from Christmas station on the Arizona Eastern Railroad. A branch of the road from Winkelman through Old Mill extends to the southern base of the hill on which the mine is situated, the distance being about $81 / 2$ miles. At present supplies are brought in by automobile on this road. When ore is shipped it is taken to Christmas station by burro pack train down Deer Creek.

Property.-The Adjust Mining Co., which has recently been reorganized, has 13 unpatented claims, on which there are a number of shafts, adits, and cuts. The principal developments are on the Blue Bird vein, shown in Figure 4, where there are more than 1,500 feet of workings. About 640 tons of ore, ${ }^{30}$ principally oxidized material, has been shipped. In May, 1922, after a shutdown of several months, the mine was reopened with the intention of carrying out sufficiently extensive development to determine the value of the ore bodies to a depth of 300 feet or more.

Character of the deposits.-The country rock is principally Cretaceous andesite, but there are some small dikes of gray porphyry, probably quartz-mica diorite. These dikes are too small to show on Plate I, but larger ones have been mapped northwest and southeast of the property. Several veins crop out, but only one, called

30 Heron, C. M., letter dated July 12, 1922. 


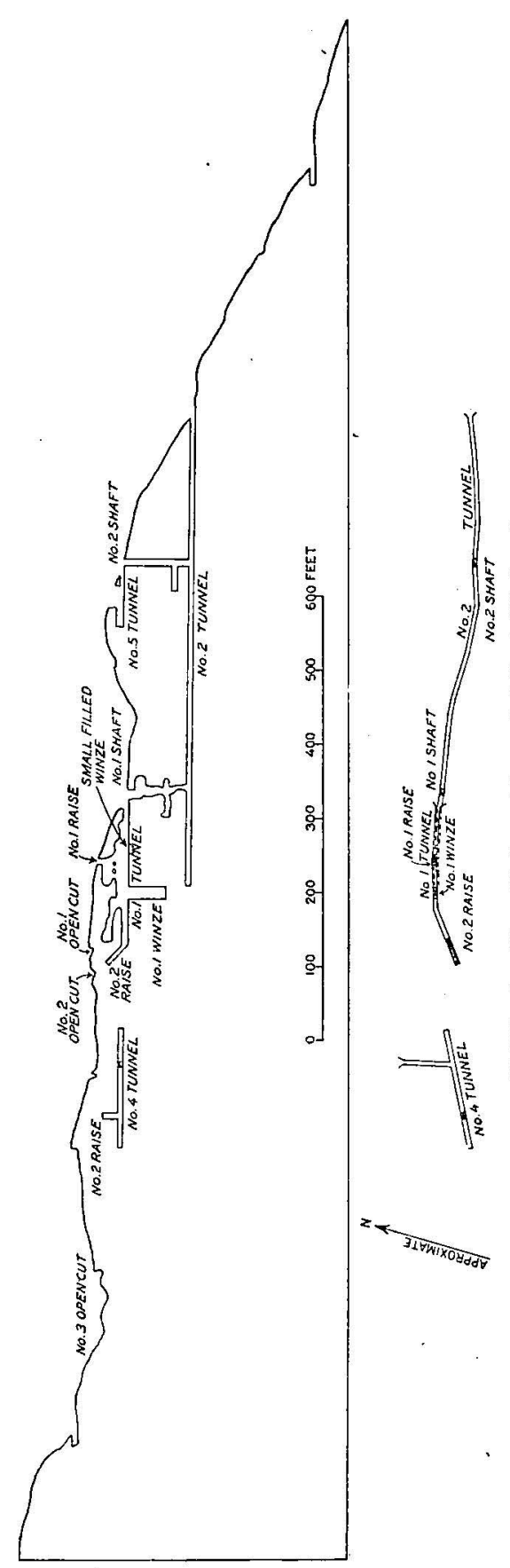

the Blue Bird vein, has been developed to any extent. The Blue Bird vein has a proved length of nearly 1,500 feet and may be much longer. Its average strilke is about N. $70^{\circ}-80^{\circ}$ E., but there are numerous rariations beyond these limits. The dip is to the northwest in some places and to the southeast in others, but in general the vein is nearly vertical. The vein has welldefined and fairly continuous slickensided walls from 3 feet or less to as much as 7 feet apart. Between the walls there is altered and brecciated country rock interleaved with bands of vein matter. The amount of mineralization varies notably. There are considerable stretches in which the vein filling is of too low tenor to be regarded as ore, and in few places does ore fill the whole space between the walls. In No. 1 tunnel the well-mineralized part of the vein is 1 to 2 feet wide. In places in To. 1 shaft and parts of No. 2 tunnel the width is as much as 3 feet. Assays show that for a length of 200 feet in No. 2 tunnel ore of sufficiently high tenor to be profitably mined is exposed. This ore shoot is also exposed in No. 1 shaft and tunnel. In addition samples of satisfactory tenor from other parts of the workings have been assayed.

The gangue minerals noted are quartz, barite, and calcite. The sulphides are galena, sphalerite, and pyrite, with small amounts of 
copper minerals, probably chalcopyrite and bornite. The andesite included in the vein is nearly everywhere thoroughly altered and largely replaced by vein minerals. The ore in places is stained with limonite, and the sulphides are partly or completely oxidized. The distribution of such material is irregular, but it appears that oxidized ore rarely extends much over a score of feet below the surface. Much of the ore mined contains about 30 ounces of silver and a small fraction of an ounce of gold to the ton, although ore containing more than 250 ounces of silver to the ton has been found. In 1920325.11 tons of ore averaging 0.15 ounce of gold and 49.99 ounces of silver to the ton was shipped, and in 1921298 tons averaging 0.15 ounce of gold and 48.46 ounces of silver to the ton. ${ }^{40}$ The shipments consisted principally of oxidized ore, more or less hand sorted. The ore which it is planned to develop in the immediate future is principally sulphide material. Tests made by the company's engineers ${ }^{* 1}$ on a composite sample of sulphide ore show that gravity concentration is hindered by the abundant barite, but flotation gives satisfactory results. To determine the distribution of the gold and silver, separate concentrates of the lead, iron, zinc, and slimes were made. It was found that the concentrates containing large proportions of lead, iron, and slime contained two or three times as much silver and gold as those high in zinc, but that the zinc concentrates contained too much silver to be discarded. These tests appear to indicate that most of the precious metals are associated with the galena and pyrite, but that some are too closely associated with the sphalerite to be separated by the methods of concentration used.

\section{SADDLE MOUNTAIN GROUP}

Location.-The claims of the Saddle Mountain group lie north' of Old Mill, on the ridge between Ash Creek and Deer Creek; southeast of the Adjust Mining Co.'s property.

History.-In 1900 the Saddle Mountain Mining Co. was organized by G. B. Chittenden, and a portable concentrating mill was erected on Ash Creek at the site of an arrastre put up by previous prospectors. The ruins of this mill still remain and the place is known as Old Mill. A little over $\$ 120$ a ton was paid by a smelter in El Paso for the first two carloads of concentrates derived from oxidized ore shipped. The ore concentrated assayed about 12 ounces in silver and $\$ 1.50$ in gold to the ton. A third car of concentrated sulphide ore was shipped. The concentrate in this car was found to average only about $\$ 30$ a ton, although the ore treated was about as rich as that from the oxidized zone previously concentrated. This result

40 Data furnished by Adjust Mining Co. from smelter returns.

4 Heron, C. M., letter dated July 12, 1922. 
led Mr. Chittenden to believe that a smelter near by was needed in order to treat the Saddle Mountain Co.'s ore successfully, and he consequently took steps to obtain what is now the Christmas mine, where there were two small blast furnaces. (See p. 53.)

After this mine was acquired the company appears to have done more work there than at its original property near Ash Creek. The Gila Copper Sulphide Co. was organized in 1909 and took over the property of the Saddle Mountain Mining Co. at both places. Work has continued intermittently on the original Saddle Mountain group up to the present time, much of it being done by lessees. Ore has been shipped from time to time, but records of the amounts are not available. In 1922 the deposits of this group and an adjoining one were being worked under lease by O. L. Orem and T. S. Sanford. In the spring they did most of their work on the claims on the north side of the ridge above Deer Creek. In July they found and mined ore on the south side above Little Gold Gluch. Most of the ore mined by them is oxidized material.

Property.-The Saddle Mountain group comprises 15 patented claims and one unpatented claim developed by a number of short tunnels, shafts, and pits. Workings are reported to aggregate 3,450 feet. ${ }^{42}$ These are scattered over the property, with no more than a few hundred feet of workings at any one place, and a considerable part of them are now inaccessible.

Character of the deposits.-The country rock at the property consists principally of Cretaceous andesite and andesitic breccia cut by a long dike of quartz-mica diorite and smaller masses of the same rock, offshoots of another large dike a little farther south. The long dike has an exposed length of over three-quarters of a mile, extending somewhat beyond the borders of the group, and a maximum width of outcrop of over 30 feet. The average strike is N. $50^{\circ}$ $\mathrm{E}$., and the dip is variable but steep. Indistinct stratification in the andesite on the south slope of Deer Creek indicates that it lies nearly horizontal. A line of exposures which may be parts of a single vein extend northeastward from the streamway in Little Gold Gulch through the saddle east of mineral monument No. 2180 down to Deer Creek just upstream from bench mark 2215. The vein in most places appears to be on the northwest side of the long quartz-mica diorite dike and roughly parallel to it, but in the saddle the dike itself is mineralized. The vein ranges in width from $21 / 2$ to 5 feet, and the wall rock is mineralized for several feet beyond these limits. The average strike is about $\mathrm{N}$. $50^{\circ} \mathrm{E}$. The dip ranges from $60^{\circ}$ to $90^{\circ}$ and is toward the northwest in some places and the southeast in others.

s2 Weed, W. H., Mines Handbook, vol. 15, p. 275, 1922. 
About 3,000 feet east of the saddle, at an altitude of 2,700 feet on the south slope of the Deer Creek valley, another vein is exposed in a 90-foot tunnel and open cuts. This vein is called the Big Rock vein, from the claim in which the principal workings are situated. It is 2 or 3 feet wide, strikes nearly east, and dips $70^{\circ}-85^{\circ} \mathrm{S}$. (See $\mathrm{Pl}$. XI, A.) The wall rock shows some alteration but little mineralization.

The two veins are of similar type. They have fairly well defined walls, in places with slickensides. Thin layers of gouge are present on parts of the walls. The unoxidized parts of the veins are made up of quartz, barite, calcite, galena, sphalerite, pyrite, chalcopyrite, and altered andesite or, in places, quartz-mica diorite. In many places banding is the dominant feature of the vein structure, but elsewhere the vein is a heterogeneous mixture of fragments composed of vein minerals and altered country rock. The wall rock in most exposures is mineralized for a few inches to several feet beyond the vein. The alteration consists in the development of chlorite, sericite, carbonate, quartz, and pyrite. Most of the pyrite noted is disseminated in small crystals in the wall rock. There are small patches of more massive pyrite in the veins in places, principally near the walls. Oxidation in these deposits is irregular and appears to extend only to shallow depths. The oxidized minerals are limonite and kindred iron oxides, anglesite, cerusite, gypsum, and small amounts of chrysocolla. Nearly all the oxidized material contains residual galena and sphalerite, but little pyrite remains in it. Gypsum occurs as flakes on tunnel walls, in small masses in the vein matter, and also as distinct veinlets an eighth of an inch or less in width. In some specimens there are numerous veinlets of gypsum approximately parallel to one another and to the banding of the original vein matter.

There are workings on both sides of Little Gold Gulch at short distances above the streamway, at about the 2,550-foot contour. On the west side is a shaft on a vein in bleached and fractured gray andesite on slips that strike about N. $80^{\circ}$ E. and $\operatorname{dip} 75^{\circ} \mathrm{N}$. On the east side of the gulch is a 75-foot tunnel in similar rock. Various slips of widely variable strike and dip are exposed in it, with narrow seams of pulverulent white gypsum on them.

Much of the rock on the east side of Little Gold Gulch north of the large dike of quartz-mica diorite that crosses it is nearly black massive basalt. This is thought to belong to the Cretaceous flows, but its relations to other rocks are not cleár, and it may be of intrusive origin. In Little Gold Gulch this rock contains rather sparsely disseminated pyrite, and in the upper part of the gulch above the 2,500-foot contour there are outcrops of similar rock 
reticulated with stringers of ribbon-banded quartz. On the upper slopes to the east the rock has a rusty color and is cut by a number of narrow shear zones containing some quartz and stained with limonite. There are a number of prospect pits here, and the shear zones are reported to contain gold. Several of the zones are offset by small faults. It is reported ${ }^{43}$ that one of them is cut by a small andesitic dike similar in appearance to those which cut the ore in the Christmas mine.

\section{LITTLE TREASURE MINE}

Location.-The Little Treasure mine is in the SE. 1/4 sec. 35, T. 4 S., R. 16 E., and the NE. 1/4 sec. 2, T. 5 S., R. 16 E. The property covers much of the northeast end of a mountain on the south side of Deer Creek and is about 9 miles by road from Winkelman and 3 miles by trail from Christmas station on the Arizona Eastern Railroad.

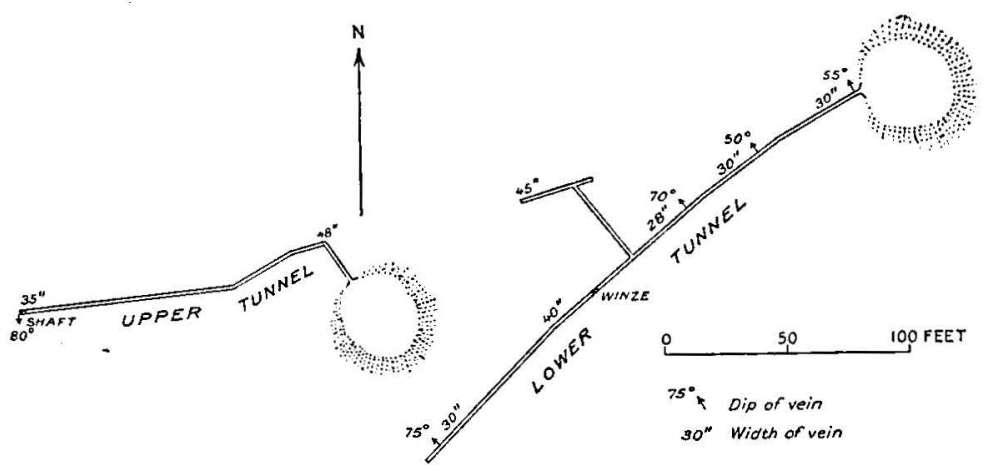

Figure 5.-Plan of principal workings at Little Treasure mine

History.-The claims were located by N. H. Mellor, of Winkelman, about 1901 and have been controlled by him since then. $\mathrm{He}$ built the road from Dudleyville south of Winkelman past this property to the coal prospects in Reed Basin in 1904 at a cost of $\$ 3,000$ and has kept it in repair as far as his mine. A few carloads of ore have been shipped.

Property.-The property comprises six unpatented claims. The principal workings are on the southeast side of the mountain, at an altitude of about 2,700 feet. They consist of two tunnels roughly 240 and 150 feet long with a shaft about 55 feet deep connecting with the upper and shorter tumnel at its face. In the lower tumnel there is a winze and short crosscut. (See fig. 5.) There are other small workings on the property, but recent work has been restricted to those described.

${ }^{43}$ Mellor, N. H., personal communication. 
Character of the deposits.-The country rock of the tunnels is a massive black basalt. This rock is doubtless of Cretaceous age and is thought to be of effusive origin. In the valley to the south a large dike of quartz-mica diorite which extends east from the Two Queens mine fingers out in a group of narrow dikes, of which the larger ones are shown somewhat diagrammatically on Plate I.

The vein developed by the lower tunnel in the Little Treasure mine has an average strike of $\mathrm{N}$. $50^{\circ}$ E., dips $55^{\circ}-75^{\circ} \mathrm{NW}$., and has a width of 30 to 40 inches of brecciated and altered rock between fairly definite walls, of which the hanging wall is the more pronounced. The part of the vein that is thoroughly mineralized has a width of less than a foot. A small amount of sulphide is contained in the oxidized ore exposed at the mouth of the tunnel, and the proportion of sulphide increases until at about the position of the winze there is almost no visible oxidation. Another vein exposed by the crosscut to the northwest strikes about N. $70^{\circ}$ E., dips nearly vertically, is 15 inches wide, and contains unoxidized sulphide ore.

The vein in the upper tunnel has an average strike of about $N$. $75^{\circ}$ E., with considerable variation. The dip ranges from nearly vertical at the mouth of the tunnel to about $80^{\circ} \mathrm{S}$. near the face. The width of vein breccia exposed is 3 to 4 feet; the walls are somewhat less well defined than those in the lower tunnel. The ore near the tunnel mouth and in the upper part of the shaft is oxidized, but at the bottom of the shaft there is some unoxidized sulphide. The vein structure is similar to that of the Big Rock vein and others of that type on the Saddle Mountain, Adjust, and neighboring properties. The hypogene minerals found are quartz, barite, calcite, galena, sphalerite, and pyrite. Oxidation was noted only near the mouths of the two tunnels and the upper part of the shaft, and even in these places it is far from complete. Specimens of ore from the lower part of the shaft and from the upper tunnel show some evidence of enrichment by descending water. There are small cavities lined with wire silver and black films on galena and sphalerite and black stringers through the gangue which resemble argentite, although the amount in the specimens collected is too small for conclusive tests. Some of the ore contains dark-red grains that are probably pyrargyrite.

\section{LEE GROUP}

J. W. Lee has claims covering most of the irregular area southeast of mineral monument 2180 bordered on the northwest and south by the claims of the Saddle Mountain group and on the northeast by the Little Treasure property. He also has some claims between Pool's mine and the Carmichael group. There are several tunnels, other workings, and trails on these claims, made in the course of 
assessment work. The deposits are similar and related to the others in this vicinity.

\section{CARMICHAEL GROUP}

J. N. Carmichael has a group of 20 unpatented claims in secs. $2,3,4,9$, and 10 , T. 5 N., R. 16 E. They lie in an arc extending from a point near the mouth of Little Gold Gulch north of the Two Queens mine and down to Ash Creek about a mile from its mouth. These claims contain a number of shafts and other working $g_{S}$ made in the course of assessment work, and veins carrying gold and silver have been exposed in them. The deposits are similar to the others in this vicinity.

Near the mouth of Little Gold Gulch, near the southeast end of this group, is a peculiar deposit. A mass of andesite shot through with numerous stringers of white pulverulent material crops out on the east side of the stream bed. In a large part of the outcrop, which is shown in Plate XII, $A$, the white material greatly exceeds the andesite in amount, and in the lower part scarcely any solid rock is present. The white material appears to be almost pure gypsum, mixed with a little calcite.

\section{TWO QUEENS MINE}

Location.-The Two Queens mine is near the summit of the ridge on the north side of Ash Creek about three-quarters of a mile northeast of Old Mill. There is a road up to the mine from Ash Creek, but it is now washed out in places. The distance from Finney, the nearest siding on the Arizona Eastern Railroad, up Ash Creek to the mine is somewhat over 3 miles.

Property.-The property comprises about nine patented claims. From 1906 to 1908 it was operated by the Central Mining \& Development Co., but since then it has been idle. Three small lots of ore averaging $\$ 36.53$ to the ton are reported ${ }^{44}$ to have been shipped to a smelter. The workings are said to comprise a shaft 260 feet deep with two 100-foot crosscuts off it, a tunnel over 400 feet long with a 90 -foot winze off it, and several shallower shafts.

Character of the deposits.-The country rock comprises Cretaceous strata of both sedimentary and volcanic origin cut by small intrusive masses. Sandstone, in part calcareous, conglomerate, and carbonaceous shale make up a large part of the Cretaceous strata. The rest consists of andesitic lava, flow breccia, and tuff. West and south of the mine are masses of gray hornblende porphyry which lie approximately parallel to the stratification of the sedimentary rocks and andesitic lava. These are probably intrusions: There is a dike 
of quartz-mica diorite at the principal shaft and another somewhat longer one a short distance to the north. The dump of the principal shaft shows andesite breccia, quartz-mica diorite, and a brown mineralized rock. Under the microscope the quartz-mica diorite is seen to be altered. It has a finer-grained groundmass than most of the rock of this type. The feldspars are sericitized, and the biotite chloritized and replaced by calcite. Pyrite, chlorite; and calcite are sparsely disseminated throughout. The alteration in the andesite breccia is similar to that in most of the Cretaceous lava in the Christmas area, except that there is more calcite than in most specimens examined. The brown rock is thoroughly altered. It now contains calcite, quartz, sericite, chlorite, epidote, and slightly oxidized pyrite. Most of the rock is a fine mosaic of quartz with small amounts of the other minerals disseminated through it, but in places calcite is segregated into masses of good-sized grains. The minerals have evidently resulted by metasomatic replacement of those of some previously formed rock during the process of ore deposition. Although the original minerals are completely destroyed, vestiges of what appears to have been a porphyritic texture can be discerned. From the appearance of this almost obliterated texture and the fact that incipient alteration of the same type has occurred in quartz-mica diorite found at the same place it is thought that the brown rock was produced by the mineralization of quartz-mica diorite.

Gold ore is reported to have been found in pockets at the surface in the early days. The tunnel is said to have cut a mass of oxidized ore, and the winze below it to have in the bottom sulphide ore carrying $\$ 16$ in gold to the ton and 10 per cent of copper.

\section{POOL'S MINE}

Location.-The principal workings of Pool's mine are in secs. 3 and 4, T. 5 S., R. 16 E., about $21 / 2$ miles by trail from Christmas station on the Arizona Eastern Railroad. There is another prospect which was worked by some of the people interested in Pool's mine on the east side of Gila River in the NE. $1 / 4$ sec. 5, T. 5 S., R. $16 \mathrm{E}$. This is about a mile up the river from the railroad siding of Finney.

Property.-The property at Pool's mine comprises 10 unpatented claims and is owned by the Ash Creek Gold Mining \& Milling Co., of Winkelman. At the place marked "Pool's mine" on Plate I is a shaft, now full of water, equipped with a whim. There is a dump of considerable size at the shaft. The vein is exposed in a series of shallow cuts for a few hundred feet northeast of the shaft, and above these cuts are some shacks. About 1,500 feet to the east is 
another inclined shaft. There are reported to be 600 feet of workings on the property. ${ }^{45}$ At the prospect on Gila River there are several short tunnels and a shallow shaft. No work appears to have been done at either place for some time.

Character of the deposits.-The country rock at Pool's mine is a dark andesite. The deposit exposed in the cuts is a shear zone a few feet wide. The mineralized rock on the shaft dump is andesite in which chlorite, calcite, quartz, pyrite, and chalcopyrite have been introduced, cut by narrow stringers of quartz containing, a little pyrite. The deposits were worked for copper and gold, but the ore found does not appear to have been of satisfactory grade. The shaft 1,500 feet farther east is at the contact between andesite and slate, both belonging to the Cretaceous bedded rocks. The slate is at the base of a considerable body of sedimentary beds which extends from the vicinity of the Two Queens mine through this place northward to Deer Creek. In the shaft is a zone of sheeted and brecciated altered andesite about 4 feet wide, with quartz stringers, calcite, and a little pyrite. The zone strikes N. $55^{\circ}$ E. and dips steeply to the southeast. There is a small dike of quartzmica diorite close to this shaft, and another just south of the shaft at the place marked "Pool's mine" on Plate I.

The prospect on Gila River is in a small fault block of Tornado limestone surrounded by Cretaceous andesitic strata and cut by a dike of hornblende porphyry 20 to 30 feet wide, with vertical dip, striking N. $20^{\circ}$ E. The limestone dips gently northeast, and the andesitic strata above lie approximately parallel to the limestone beds. At one place on the contact is a mass of quartz-mica diorite cutting both andesite and limestone. The outcrop is so small that it could not be shown on Plate I. The west boundary of the limestone block appears to be a fault, the limestone being on the upthrown side.

On both sides of the hornblende porphyry dike the limestone shows irregular recrystallization and replacement with quartz, fluorite, pyrite, and chalcopyrite. The sulphides are partly oxidized to limonite, hematite, and a small amount of malachite. The porphyry is also in part altered and stained with limonite. The altered limestone exposed is small in amount. Locally the replacement spread out along bedding planes.

\section{HOOSIER GROUP}

Location.-The Hoosier group is on Sulphur Gulch in secs. 4 and 5, T. 5 S., R. 16 E. The principal workings are in the NW. $1 / 4$ sec. 4 . Sulphur Gulch empties into Gila River about 1,000 feet above the

45 Weed, W. H., Mines Handbook, vol. 15, p. 219, 1922. 
mouth of Ash Creek and half a mile from the railroad siding of Finney.

Property.-The Hoosier group comprises about eight unpatented claims owned by J. Miles and C. H. Crozier. About 1,500 feet from the mouth of Sulphur Gulch, in a side gulch, is a shaft on the vein. The same distance up the main gulch and some 50 feet vertically above it on the north side is another shaft, reported to be 48 feet deep, and a short tunnel. There are reported to be two or three shallow shafts on the vein between the two mentioned. In the main gulch a crosscut tunnel is being driven by $\mathrm{Mr}$. Miles to intersect the rein exposed in the 48 -foot shaft and the short tunnel. He has a tent house near the mouth of Sulphur Gulch.

Character of the deposits.-Most of the rock on this property is andesite of various types, including light-colored hornblende porphyry. At the shaft first mentioned above there is a small mass of Tornado limestone. (See Pl. I.) The block is bounded on the south by a slip that strikes N. $75^{\circ} \mathrm{E}$. and dips $80^{\circ} \mathrm{S}$. 'The shaft has been sunk on this slip, the rock along which is mineralized. The limestone block is about 200 feet long in a northwesterly direction and 100 feet wide. The southwest boundary appears also to be a fault with downthrow to the southwest. Beyond the limestone block to the northwest this fault is marked by a zone about 20 feet wide of fault breccia composed of hornblende porphyry, dark andesite, and limestone. The mineralized rock on the dump of the shaft here appears to be limestone almost completely replaced by quartz, chlorite, magnetite, specularite, and pyrite. The vein in the tunnel on the hillside 1,500 feet to the northeast is about 3 feet wide, stands nearly vertical, and strikes $\mathrm{N} .65^{\circ} \mathrm{E}$. The vein matter is thoroughly oxidized and consists essentially of limonite and quartz. In the lower part of the 48-foot shaft a small amount of pyrite is exposed in gangue consisting largely of chlorite and quartz. A little pyrite is exposed in the andesite in the tunnel below, but in May, 1923, the tunnel was not yet long enough to reach the vein exposed in the tunnel and shaft on the hillside above it.

\section{RIEDER \& BAILEY GROUP}

Location.-The Rieder \& Bailey group is on the south side of Ash Creek nearly a mile up the winding streamway from its mouth. The principal workings are in the NW. $1 / 4$ sec. 9 , T. 5 S., R. 16 E.

Property.-This group comprises several unpatented claims, and $\mathrm{Mr}$. Rieder has other claims covering much of the W. $1 / 2$ sec. 5 and probably extending beyond. There are a number of workings in this area, but none are extensive. In May, 1922, Mr. Rieder was working on the south side of Ash Creek a short distance below the mouth of 
the gulch down which the road from Winkelman comes. Here he has two tunnels side by side. One of these has caved near the face, where mineralized and fractured rock is reported to have been encountered, and the other was being driven to open up this ground, if possible, without resorting to timbering.

Character of the deposits.-The rock in this part of the Christmas area is a complex of Cretaceous effusive rocks and fine-grained intrusive porphyries. Northwest and southeast of the tunnels mentioned above are the dikes of quartz-mica diorite shown on Plate $I$, and there are smaller masses not mapped. The rock in and near the tunnels is principally gray hornblende porphyry. Several small slips stained with iron and copper salts are exposed in the tumnels. Specimens found loose at the mouth of one of the tunnels, presumably from the mineralized zone in the caved ground, contain quartz-mica diorite cutting chloritized andesite. The diorite is altered, contains numerous pyrite crystals, and is cut by quartz stringers containing chrysocolla.

In the general vicinity of these tunnels there are a number of poorly defined shear zones in andesite and hornblende porphyry. The outcrops of these zones consist of altered country rock with quartz stringers containing limonite, chrysocolla, other oxidation products, and small amounts of unoxidized pyrite, specularite, and magnetite. Some of the specimens furnished by Mr. Rieder yield free gold when panned.

FAULL GROUP

A group of copper claims belonging to James Faull lies on both sides of Gila River just above Christmas station. At the time of visit assessment work was in progress in a tunnel in Cretaceous andesite a short distance south of two dikes of quartz-mica diorite on the east side of the river. In the tunnel streaks of altered andesite containing pyrite crystals are exposed.

Other claims in this vicinity are held by Mike $O^{\prime} B$ rien and by Simon Beaurle, but little work has been done on them for some time.

\section{CHRISTMAS MINE}

Location.-The Christmas mine, which is the largest in the aren mapped, is on the west side of the valley of Gila River about 8 miles by road north of Winkelman, in sec. 30, T. 4 S., R. 16 E. (unsurveyed); the property extends also into secs. 19, 20, and 29 of this township and sec. 25, T. 4 S., R. 15 E. The branch line of the Arizona Eastern Railroad has it\$ terminus at Christmas Station, which is just above the channel of Gila River and about 650 feet vertically below the settlement at the mine. The station and mine are 
connected by a winding road over $1 \frac{1}{2}$ miles long, and by an aerial tramway nearly as long.

History. ${ }^{46}$-Dennis O'Brien and William Tweed first staked claims on what is now the Christmas property about 1880. About $1882 \mathrm{Dr}$. James Douglas, acting for the Phelps-Dodge Co., bought Tweed's claims and obtained options on O'Brien's. He built a wagon road from Picacho, bridged Gila River above the mouth of Ash Creek, and set up two small water-jacket furnaces for smelting the ore. A small amount of oxidized copper ore was mined. In 1884 operations were terminated because the deposits were then inside the San Carlos Indian Reservation, and mining was prohibited. From this time until the reservation boundary was shifted, only annual assessment work was done. On December 22, 1902, through the efforts of G. B. Chittenden, of the Saddle Mountain Mining Co., an Executive order was issued restoring to the public domain the part of the reservation in which the deposits lie. The area restored is a triangle about 15 miles on a side.

Just before Christmas, 1902, Chittenden and three other men located a group of claims covering the deposits. The mine was named from this circumstance. The Phelps-Dodge Co. protested, but before the case came to trial a compromise was effected, and the Saddle Mountain Mining Co. bought the Phelps-Dodge holdings, consisting of about 40 mining claims. After a test of the ore with one of the furnaces already installed the Saddle Mountain Mining Co. purchased another fumace having a rated capacity of 150 tons. In July, 1905, this furnace was blown in, and it continued in operation until the spring of 1907 , when the mine was shut down. The product sold is reported to have had a value of $\$ 872,000$. During this time 113,322 tons of ore was mined and the development of the mine was carried to a depth of 300 feet through two shafts. In 1909 the Gila Copper Sulphide Co. was formed and took over the property of the Saddle Mountain Mining Co. This new company operated the Christmas mine until about 1914. From 1915 to 1919 work was continued under contract by the American Smelting \& Refining Co. This company gave up the management in January, 1920, and the mine was again shut down in April, 1921. From 1915 to 1920, inclusive, 415,264 tons of ore was mined.

Property.-The Gila Copper Sulphide Co. owns the Saddle Mountain group of silver claims (see pp. 43-46), 640 acres of coal land in the lower coal field in Reed Basin east of the Christmas area, and 35 patented and 21 unpatented claims at the Christmas mine, including the 18 unpatented claims of the Shamrock group southwest of Christmas, recently purchased. The developments at

¿ Compiled from data supplied by G. B. Chittenden and others. 
the Christmas mine include five shafts, over 16,000 feet of lateral workings, and a number of stopes. (See Pl. XIII.) All the stopes are above the 400 -foot level. The No. 3 shaft is the only one now equipped for operation. It has two compartments for cages and a ladderway and is 800 feet deep, with workings radiating from it at the $100,200,300,350,400,500$, and 800 foot levels. The pumps are installed on the 500-foot level, and the shaft below this is at present full of water. Somewhat more than 2,000 feet southeast of the No. 3 shaft are the Christmas workings, made in the early days. These consist of a terraced open cut with numerous short tunnels penetrating the mountain side at each terrace level. A view of these workings is shown in Plate XII, $B$. The Devils Gate incline starts at the surface in this vicinity and slopes down to the 300-foot level of the main mine. The slopes north and west of the Hackberry shaft are also honeycombed with old shallow workings. Some workings on the Shamrock group southwest of Christmas have recently been purchased by the Gila Copper Sulphide Co., but little systematic development work has yet been done on these claims.

The settlement of Christmas is about 2,000 feet east of the collar of No. 3 shaft and down the slope from it. The company's offices and shops, a post office, a school, and sufficient houses for several hundred people are situated there. The houses are owned by the company and used by its employees, principally Mexicans. Although the mine was not working when visited, a number of Mexican families were still living there. Houses for those of the engineering staff who have families are grouped by themselves at a little distance from the rest. The superintendent, A. L. Gorman, and his brother, J. Gorman, were the only Americans employed at the property at the time of visit.

Character of the deposits.-The rocks that crop out in the vicinity comprise Quaternary alluvium and slide rock, Cretaceous andesitic strata, Tornado limestone, and dikes of quartz-mica diorite and other rocks. (See Pls. I and XIII.) All the limestone in the vicinity of the mine is altered in varying degree by contact metamorphism. The limestone and the ore derived from it are cut by narrow dikes of altered andesite. - The material mapped as older alluvium on Plate I is in large part composed of water-rounded and roughly sorted boulders, pebbles, and sand but also includes angular blocks, which are probably talus from the upper slopes. The greater part of both the talus and the water-transported material has a weak calcareous cement. In Plate XIII, which is intended to bring out the relations of the ore bodies to the geologic structure, this covering material has, for the sake of clearness, been omitted. The andesitic rocks overlie the Tomado limestone on the southwest and butt against it in fault contact on the northeast. The traces of bedding in the 
andesite are too indistinct and variable for accurate determination of the attitude of the beds, but in general they appear to strike northwest and dip southwest at low angles. There seems to be little angular discordance between them and the underlying Tornado limestone. The andesitic strata east of the mine appear to dip west or southwest. South of the old Christmas workings, in limestone beds comparatively undisturbed by faults, the strike is $\mathrm{N}$. $70^{\circ} \mathrm{W}$. and the dip is $10^{\circ} \mathrm{SW}$. The mass of altered limestone in the mountain spur north of No. 3 shaft has an inclination of a few degrees to the west. Near the shaft it is in general nearly flat-lying. (See Pl. XIV, A.) A mass of quartz-mica diorite partly mantled by older alluvium crops out from a point about half a mile east of Christmas westward along the valley in which No. 3 shaft is situated. The cover of detritus makes its exact outlines indeterminate, but it is evidently the largest mass of such rock that crops out in the Christmas area. It is essentially a thick dike with. a number of narrow apophyses extending from it. The bodies of similar rock exposed farther east on the road to Christmas station and also on the main road south of the station are doubtless connected with it in depth. East of Christmas the main dike has a width of nearly 1,000 feet, and at the town it is probably even wider, but it narrows abruptly to the west. At No. 3 shaft the outcrop is only about 400 feet wide, and 700 feet west of the shaft it appears to be less than 150 feet wide. The strike is somewhat north of east, and the dip is steep. The section through No. 3 shaft indicates that here the average dip is about $70^{\circ}$ NW. The section through No. 1 shaft, 350 feet farther west, shows a similar dip. The section through No. 3 shaft, shown in Plate $\mathrm{XV}$, is drawn from one prepared by $\mathrm{A}$. Locke and $\mathrm{G}$. N. Bjorge, with some of the details omitted and the probable boundaries of the intrusive mass between levels drawn in, to bring out the general relations more clearly. The section through No. 1 shaft, shown in Figure 6, is drawn from one by S. H. Sherman. Both sections show that slivers of altered limestone are included in the diorite, lying approximately parallel to the walls of the dike. The engineers of the Gila Copper Sulphide Co. have made a distinction between coarse-grained and fine-grained quartz-mica diorite. The fine-grained rock makes up the greater part of the intrusive masses and is reported to be cut in places by the coarse-grained rock. The latter is, however, probably merely a somewhat later phase of the same intrusion, for there appears to be no essential petrographic difference between rock termed coarse grained and that termed fine grained on the company's maps.

There are numerous faults and slips in the rocks in the mine and its vicinity. Much the largest of these is the one known as the Christmas fault. (See p. 22.) In the vicinity of Christmas this 
fault has an irregularly curvilinear outcrop, denoting that the fault surface or combination of surfaces is not plane. The average strike is about N. $60^{\circ} \mathrm{W}$., and the dip is steep to the northeast. The rocks on the northeast side have slipped down relative to those on the southwest at least 500 feet and perhaps more than twice that.

The Christmas fault is reached by drifts in the northeast end of the developments on the 300-foot level, now caved and inaccessible. The map of this portion of the mine in the report by Locke and Bjorge shows that the footwall is composed at one place of altered calcareous shale and at another of garnetized limestone, and that the

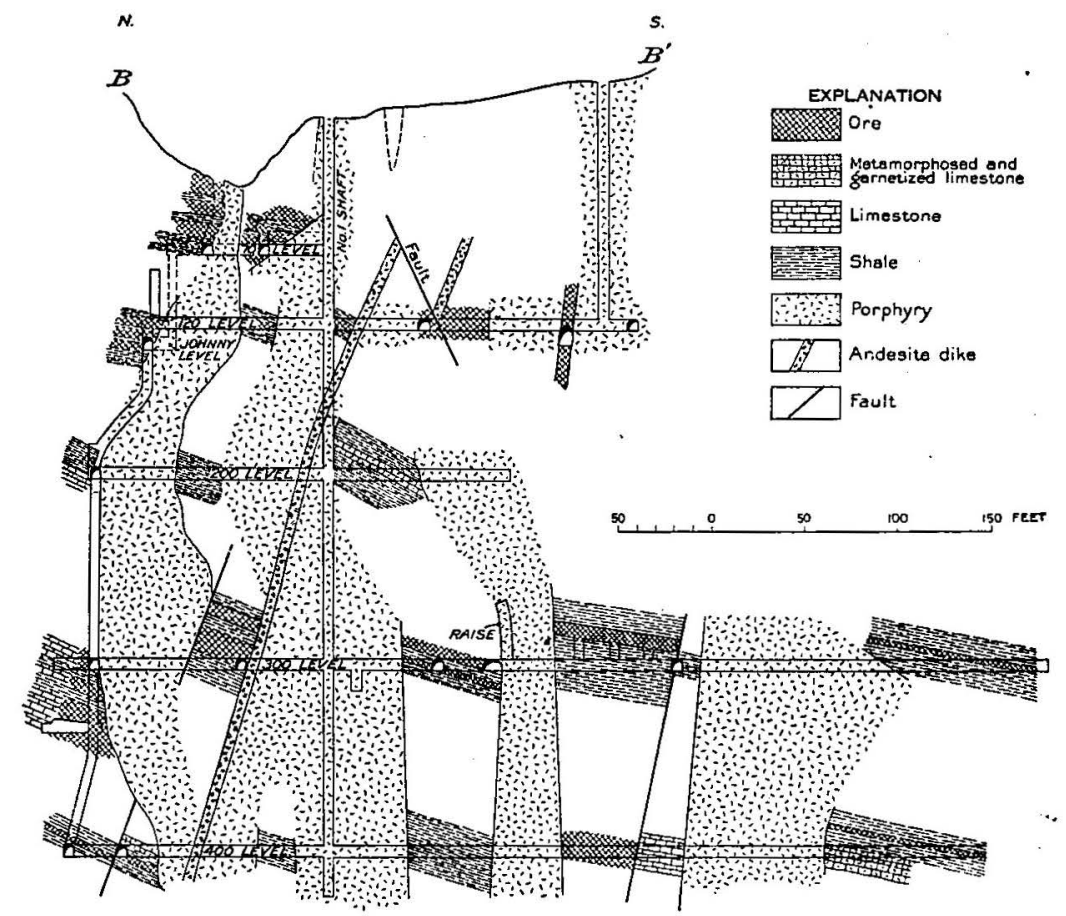

Figure 6.-Geologic section through No. 1 shaft, Christmas mine, May 31, 1910. For line of section see $B-B^{\prime}$, Plate XIII. From drawing furnished by Gila Copper Sulphide Co., Christmas

hanging wall consists of crushed andesite with quartz-mica diorite beyond the andesite. The rock in the fault zone itself is crushed diorite with fragments of limestone. This zone has an average strike of about $\mathrm{N}$. $70^{\circ} \mathrm{W}$. and dips $65-67^{\circ} \mathrm{NE}$.

The evidently abrupt westward swing of the contact between the Cretaceous rocks and the limestone south of No. 3 shaft under the cover of alluvium and slide rock and the comparatively greater uplift of the limestone north of the shaft suggest strongly that there has been faulting here, with the strike of the fault roughly parallel to that of the main diorite mass and the downthrow on the south. 


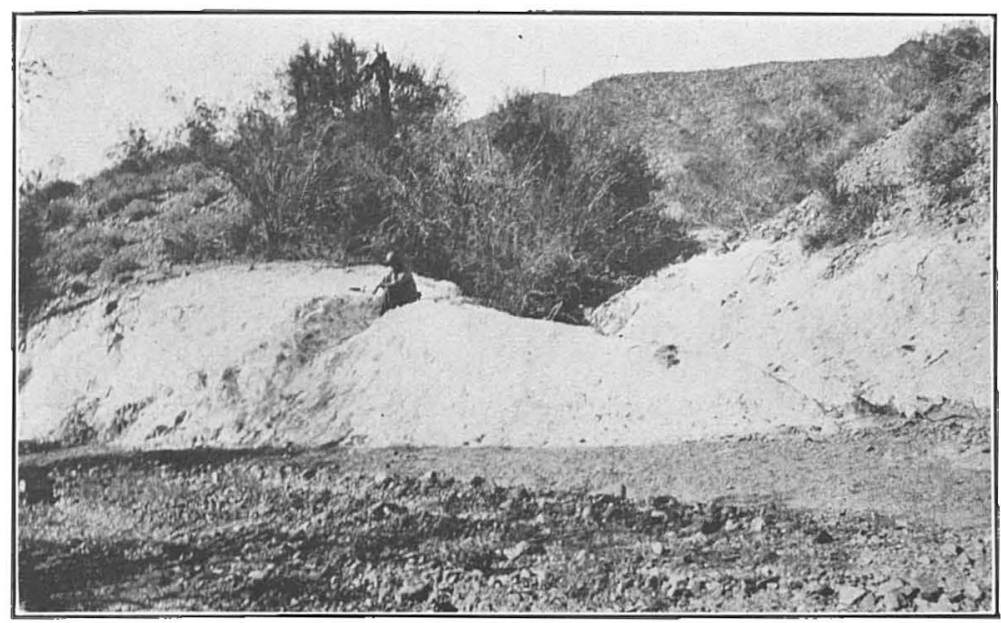

A. OUTCROP OF GYPSUM ON LITTLE GOLD GULCH

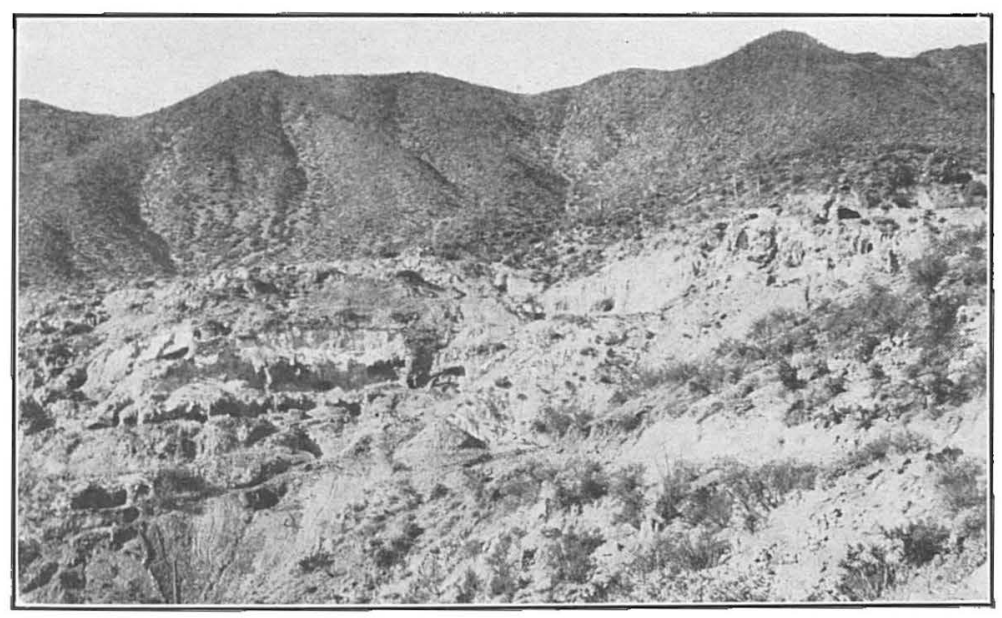

B. THE OLD CHRISTMAS WORKINGS 


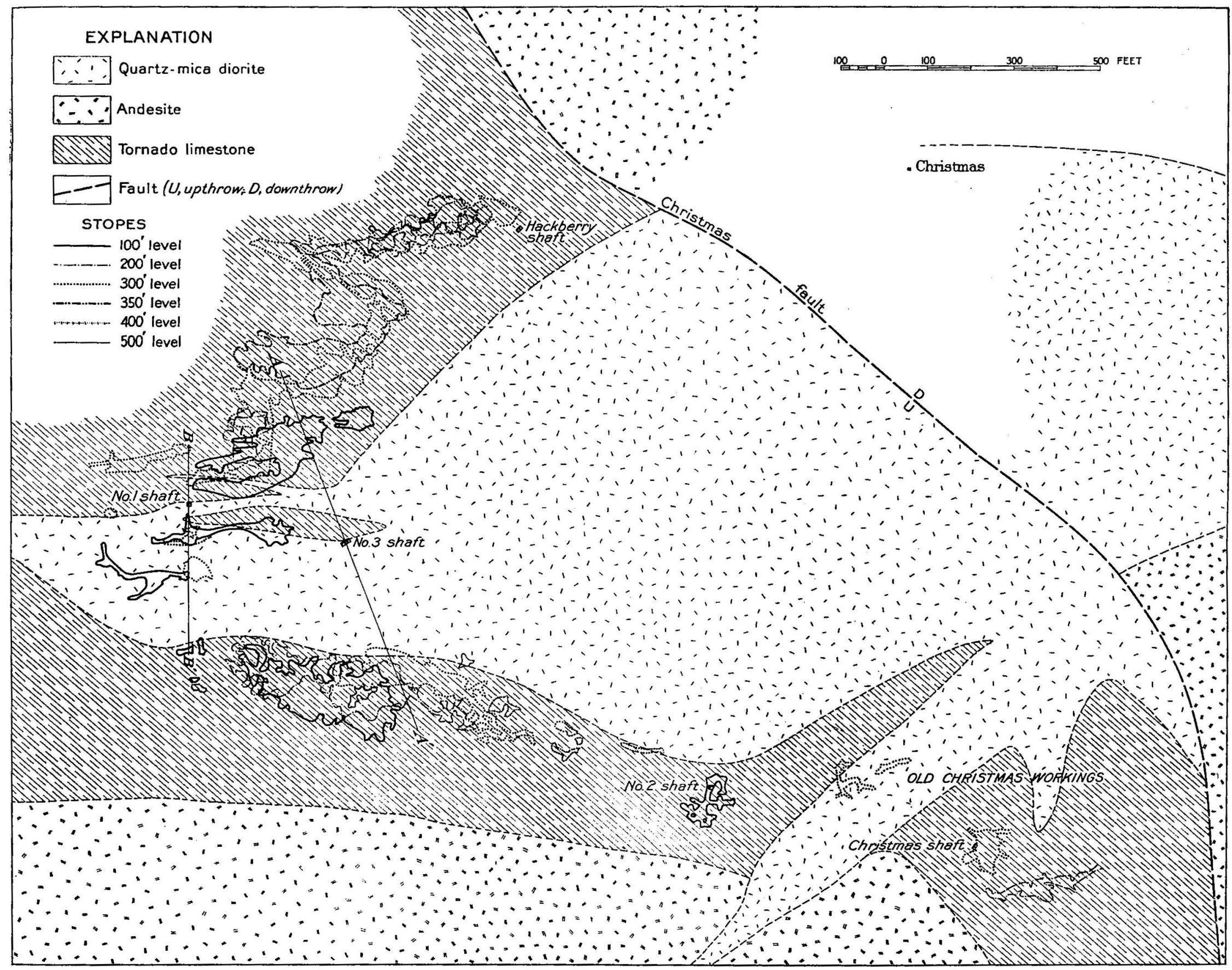

MAP SHOWING RELATIONS OF THE STOPED-OUT ORE BODIES OF THE CHRISTMAS MINE TO THE SURFACE GEOLOGY Geology from Plate I, with modifications from maps and sections furnished by Gila Copper Sulphide Co. Stopes from mine maps of Gila Copper Sulphide Co. 


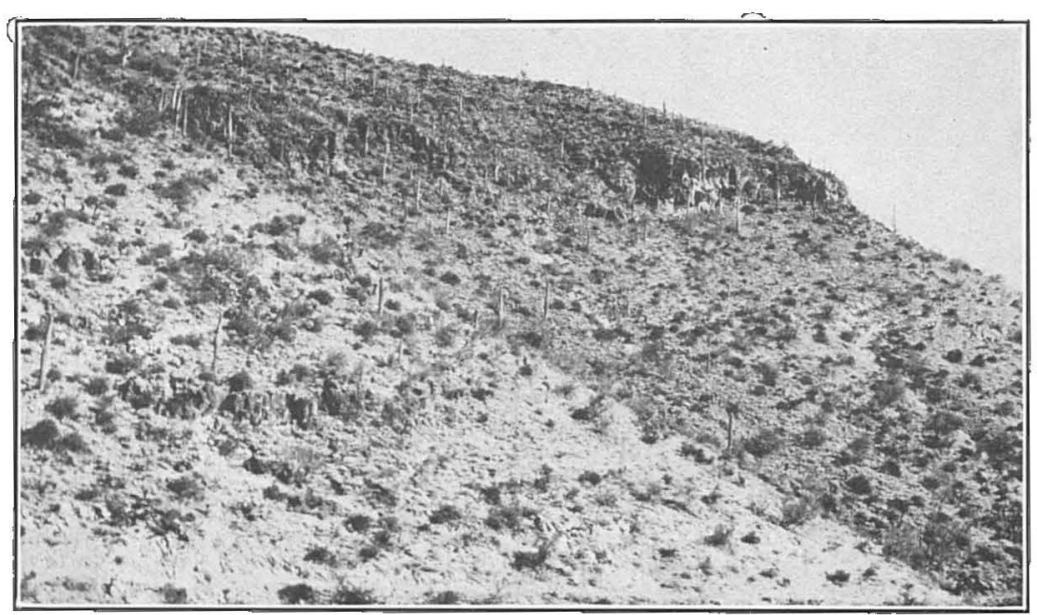

A. CONTACT-METAMORPHOSED LIMESTONE NORTH OF NO. 3 SHAFT, CHRIS'TMAS MINE

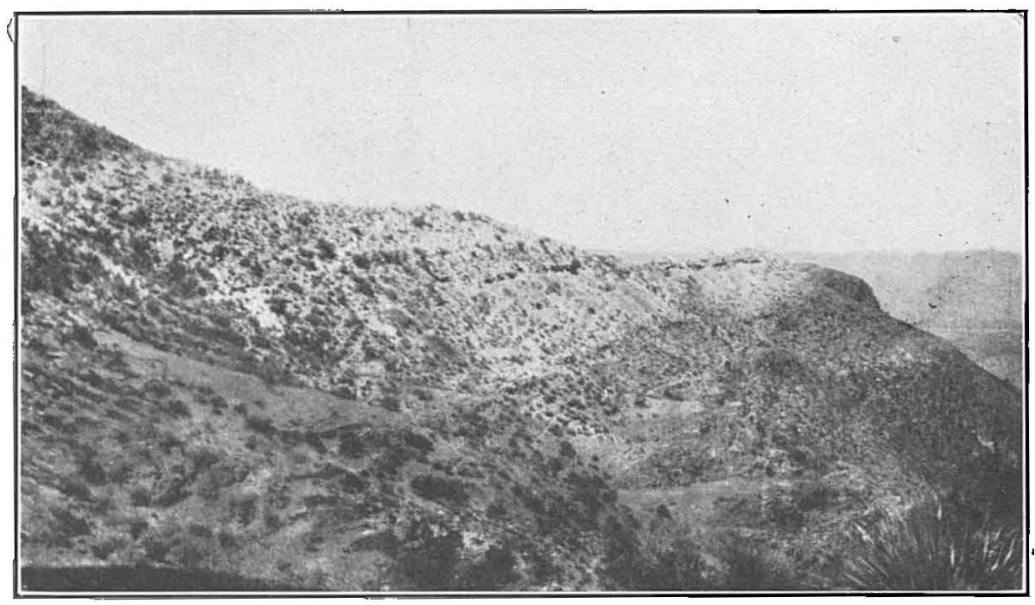

B. TUNNELS CONSTITUTING THE PRINCIPAL WORKINGS OF THE LONDON-ARIZONA MINE 


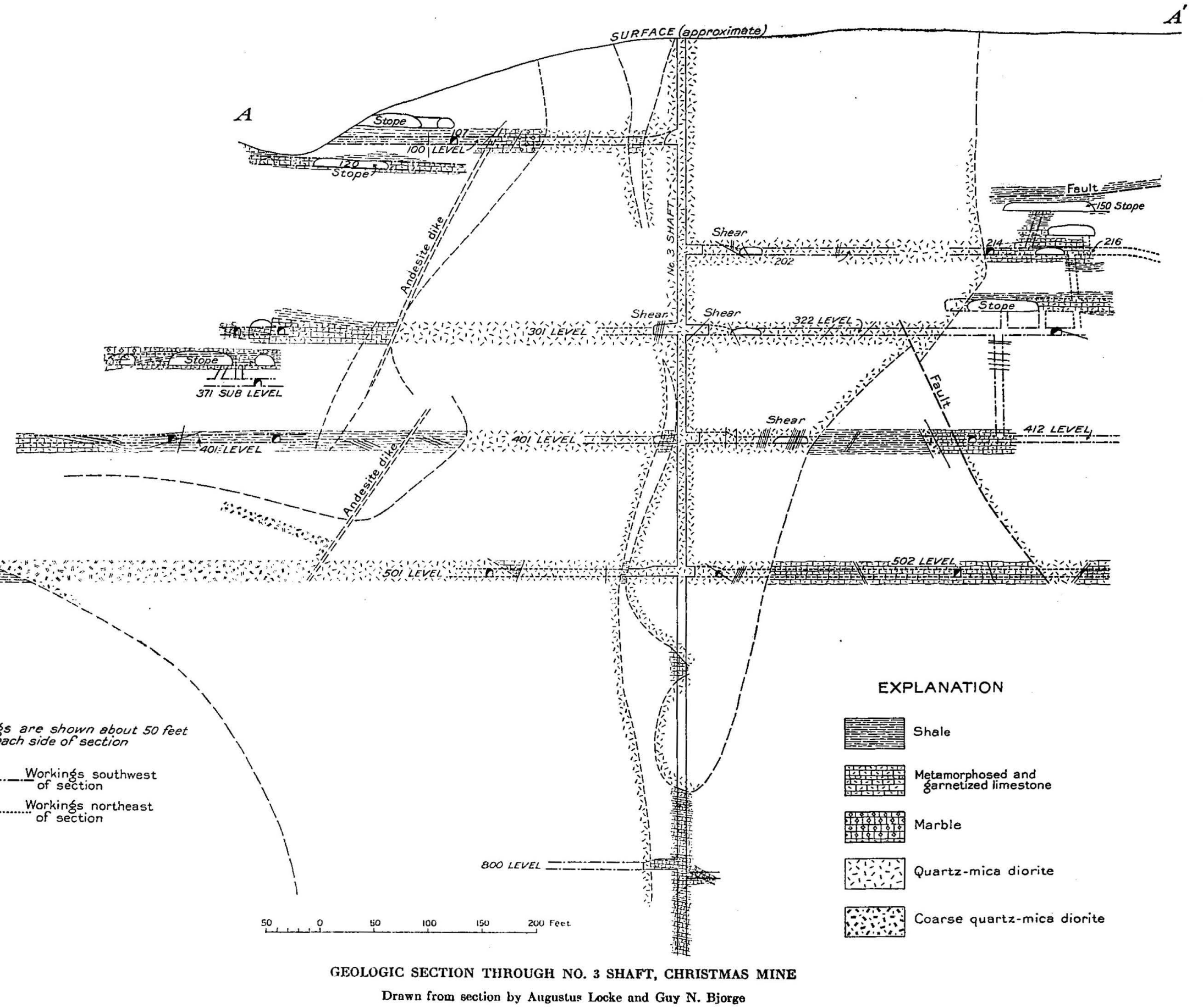

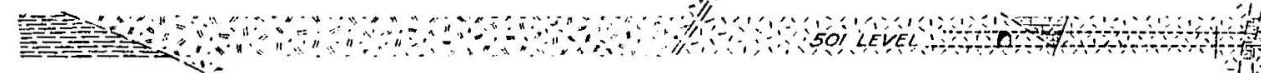

Workings

from each side of section

Workingss southwes Workings northeast

Drawn from section by Augustus Locke and Guy N. Bjorge

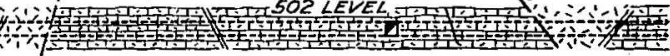

\section{EXPLANATION}

Shale

Metamorphosed and
garnetized limestone

Marble

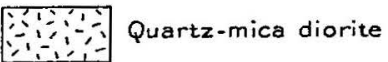

Coarse quartz-mica diorite 
Such a fault would result in carrying the limestone south of the shaft far enough down to put the base of the formation probably well below the battom of the shaft. On the north, however, it would seem that the base of the Tornado limestone should be found at less depth. There are so many minor faults in this vicinity that accurate stratigraphic measurements are difficult to make. From available maps it appears that the Tornado limestone here has a thickness of the order of 1,000 feet, of which about half is above the collar of No. 3 shaft. As the limestone at this locality is only slightly inclined the base of the formation north of the shaft would lie at about the 500-foot level. If the Tornado here is thicker than 1,000 feet its base would be correspondingly lower. Measurements by Locke and Bjorge on Tornado Peak, about 21/2 miles west of Christmas, show that 1,530 feet of limestone and interbedded shale and a few narrow sills of dioritic porphyry are exposed here, of which about 1,200 feet has been assigned to the Tornado limestone and the remaining lower beds to the Martin limestone. If the Tornado limestone at Christmas is of this thickness its base would come somewhat more than 700 feet below the collar of the No. 3 shaft, and probably this is its approximate position. Stratigraphically below the Tornado is the Martin limestone, which has an average thickness of about 325 feet. $^{47}$ Certain beds of this formation are susceptible of replacement by mineralizing solutions, as is shown at the London-Arizona mine and elsewhere.

Besides the two faults just discussed there are numerous others of less throw. The largest of these encountered by the underground workings are shown in the section in Plate XV. A fault with rather steep dip to the southeast is shown extending from the 300 foot to the 500-foot level. Above the 200-foot level on the south side is a flat-lying fault along which there is reported to be much brecciation and evidence of movement. Numerous small slips and zones of sheeting appear throughout the mine. A number of examples of these are shown in the sections in Plate XV and Figure 6. On the surface also many such minor faults are visible. A number can be discerned in the view shown in Plate XIV, $A$. These slips vary widely in attitude. They dip at all angles from the horizontal to the vertical, and the inclination of a large proportion of them is. toward the northwest. The strikes also vary greatly, but a large part of those shown on the level maps prepared by Locke and Bjorge are within a range of $30^{\circ}$ either side of east.

The formation of the faults described above has probably occupied considerable time. Where ore is crushed or displaced by a

4T Ransome, F. L., The copper deposits of Ray and Mlami, Arlz.: U. S. Geol. Survey Prof. Paper 115, p. 46, 1919.

$31463-25-5$ 
fault, it is obvious that the movement was of later date than the ore deposition, and it is probable that some such movements have taken place in comparatively recent time. On the other hand, there is evidence of faulting before the deposition of the ore, and probably before the intrusion of the quartz-mica diorite. The shape of the stopes shown in Plate XIII may be assimed to correspond npproximately to the shape of the ore bodies mined, with, of course, exceptions resulting from incomplete mining of the ore and other causes. A large portion of the stopes are elongated in a direction a little north of east, and many have narrow extensions at their ends that have similar trends. These facts appear to indicate that the solutions that deposited the ore found most easy access and their products were consequently concentrated along roughly parallel paths whose average trend was a little north of east. It is probable that these paths of easy access were fractures in the rocks produced before the advent of the mineralizing solutions. Movement on the Christmas fault and on the large fault that strikes parallel to the main diorite dike is believed to have been initiated before the intrusion of the diorite. It is possible that a large part of the movement preceded the intrusion and that the diorite came in along a zone of shearing thus produced. This inference would help to explain the thin slivers of limestone in the diorite. The fracturing along the Christmas fault disclosed in drifts on the 300 -foot level proves that movement has taken place on this fault subsequent to the formation of the diorite and the ore, and there is also evidence of postmineral movement along faults with northeasterly strikes, but no such movements appear adequate to account for the displacement of the limestone south of No. 3 shaft relative to that north of the shaft. The relations of the quartz-mica diorite to the Christmas fault suggest that much of the movement on that fault took place before the intrusion of the diorite. Both on the 300-foot level and in the open cut at the old Christmas workings narrow apophyses of the diorite extend out along the fault, as if following lines of weakness produced by previous fracturing.

All the limestone in the vicinity of Christmas shown on Plate I is 'metamorphosed, and the metamorphism continues westward beyond the limits of the area mapped, though it dies out gradually in this direction. The amount and character of the alteration differ markedly in different places and in different beds in the same place. The rocks resulting from the metamorphism may be grouped into four principal types-meta-shale, silicified limestone, marble, and garnet rock-with all sorts of gradations between them. The metashale is derived from the impure, shaly beds in the limestone series. It is a fine-grained, indistinctly banded rock, light green in most specimens. It contains quartz, epidote, a little garnet, and calcite. 
Much of the quartz has been recrystallized, but in places the original detrital texture has been preserved. Most of the rock of this type contains little or no sulphides, but small masses of ore are reported to have been found in it in places. Silicified limestone appears to be of irregular distribution. In some places masses of varying size and irregular shape consisting essentially of quartz with minor amounts of garnet, sulphides, and other minerals are inclosed in garnet rock. Elsewhere there is massive rock consisting of small interlocking grains of quartz and flakes of partly chloritized biotite. In places the quartzose rock contains drusy cavities and is probably to be interpreted as of the nature of vein filling, but in other places the rock is clearly the result of a metasomatic replacement of limestone. The marble is merely limestone that has been recrystallized but in other respects is little altered. It is more nearly white than the unaltered limestone and of variable but in general coarser grain. In places near ore it is crisscrossed by tiny veinlets containing pyrite and a little chalcopyrite. The garnet rock makes up much the greater part of the altered limestone seen in the mine or on the slopes above it. It consists largely of green andradite garnet, with varying amounts of dark reddish-brown andradite, epidote, chlorite, an amphibole resembling pargasite, quartz, vesuvianite, and in places the metallic minerals of the ore. Wollastonite is reported by Locke and Bjorge to have been found in this rock. The garnet rock lies on both sides of the thick dike of quartz-mica diorite on the west or footwall side of the Christmas fault. The boundaries on the sides away from the intrușive rock are irregular. Masses of garnet rock were observed in places to be bordered by zones of marble. In a number of places the transition between garnet rock and marble is abrupt, but gradations between the two can also be found. The garnet rock has evidently been formed by replacement of the more calcareous beds of the formation. Small residual masses of marmarized limestone are present in it in places. The bodies of garnet rock are separated by beds of meta-shale, and in a few places, according to Locke and Bjorge, by small sills of highly altered quartzmica diorite.

Certain portions of the garnet rock carry notable quantities of metallic minerals and locally contain enough copper to constitute ore bodies. The hypogene metallic minerals are magnetite, chalcopyrite, pyrite, and small amounts of sphalerite and galena. One specimen was found in which magnetite occurs in a form resembling that of micaceous hematite. The gangue consists of the minerals of the garnet rock listed above and in places veinlets of chalcedony. Bornite is a prominent constituent of the ore and may be hypogene, although in places it seems more probably a product of later enrichment, like the chalcocite and covellite that are rather generally dis- 
seminated in the ore on and above the 300-foot level. The oxidized metallic minerals noted in the ore bodies near the surface are malachite, azurite, chrysocolla, native copper, limonite, hydrous manganese oxide, and copper pitch ore. Gypsum veinlets are present in some of the oxidized ore. The company's records show that in $\mathbf{1 9 1 5}$ to 1920 the ore shipped contained on the average 0.007 ounce of gold and 0.28 ounce of silver to the ton, 2.8 per cent of copper, 18 per cent of iron, 26 per cent of lime, 33 per cent of silica, and 2.5 per cent of sulphur.

The following statements regarding the distribution of the minerals in the deposits are abstracted from the report by Locke and Bjorge. They prepared detailed geologic maps of the workings accessible to them, which include much that can not now be examined. Ore is found in the limestone near the more highly mineralized parts of the quartz-mica diorite, and this fact may be used as a guide in prospecting. The garnet rock near the contact with the main intrusive mass contains much magnetite and little copper. The blocks of limestone included in the intrusive rock are highly metamorphosed and likewise contain much magnetite but little copper. Some of the best ore has been found in limestone masses projecting into but not surrounded by the diorite.

The quartz-mica diorite in the mine and in the open cut of the old Christmas workings is in general fairly fresh. The feldspars are scarcely more thoroughly sericitized than those in similar rock elsewhere. The biotite is, however, somewhat more bleached and chloritized than in outcrops at a distance, and epidote, calcite, pyrite, and secondary quartz are developed in places but nowhere abundantly.

In several places under ground there are narrow dikes of purplish andesite cutting garnet rock, ore, and diorite. The andesite consists of plagioclase of the approximate composition of andesine, hornblende, and epidote. Except for the introduction of the epidote, the rock shows little alteration.

\section{MELLOR PROSPECT}

N. H. Mellor has, besides the Little Treasure mine, described on page 46, a small group of unpatented claims on both sides of Gila River just below Christmas. The rock in this vicinity is Cretaceous andesite cut by irregular masses of a bleached and altered igneous rock that may be sericitized quartz-mica diorite, containing a little pyrite in places, and by masses of typical and comparatively unaltered quartz-mica diorite. There are a short tunnel and shallow shaft in one of the masses of altered igneous rock, and some other small workings elsewhere. On the east side of the river some small outcrops of gossan appear in the bank of a tributary wash, 
and the outcrop of diorite at this place shown on Plate I has a little copper stain. Near by there are a few other outcrops of the diorite containing inclusions of andesite, but they are too small to show on the map.

\section{LONDON-ARIZONA MINE}

Location.-The property of the London-Arizona Consolidated Copper Co. covers a broad area near and for the most part north of Tornado Peak, in Gila County. The settlement of Chilito, near the London-Arizona mine, is about 5 miles by road north of Hayden, and the property extends somewhat less than 2 miles east and more than $11 / 3$ miles west of Chilito, with a width of more than a mile.

History. ${ }^{43}$-The deposits of the present London-Arizona mine were located about 1880 by Watson. The claims were later acquired by D. W. O'Carroll and about 1906 sold to the Dripping Springs Mining, Smelting \& Reduction Co., which was reorganized about 1908 as the London-Arizona Copper Co. In 1913 the LondonArizona Consolidated Copper Co. was formed as a merger of the London-Arizona, London-Range, London-Shamrock, and Ball Copper companies. Work was carried on intermittently until 1920, principally by lessees. From a set of tunnels east of Chilito, 15,443 tons of ore ranging in tenor from 2.75 to 18 per cent copper was shipped to the Hayden smelter. The average grade of this ore is estimated by Mr. Scott as perhaps 4.5 per cent of copper. From the vicinity of the Curtin shaft 1,016 tons of lead ore and 51 tons of zinc ore were shipped, principally from shallow workings. Since then the Shamrock group has been purchased by the Gila Copper Sulphide Co. There is at present no activity on the claims of the company, and ownership of a large part of them has been reassumed by Mr. O'Carroll.

Property.-The London-Arizona Consolidated Copper Co., when organized, had 132 unpatented claims. The workings include a shaft about 180 feet deep near the road on London-Range ground less than a mile southwest of Chilito; the group of tunnels of the London-Arizona mine just east of the settlement (Pl. XIV, B) ; the Curtin shaft, 325 feet deep with short drifts off it, about a mile east (Pl. XVII, $A$ ); the O'Carroll and Ball shafts, still farther east; and a number of smaller workings. The London-Arizona workings, from which most of the output has come, consists of about 60 tunnels $^{49}$ at short intervals in a mineralized limestone bed. These tunnels extend about 2,000 feet along the mountain side. Some of

${ }^{48}$ Data from Harry Scott, of Chilito, Ariz., and Weed, W. H., Mines Handbook, vol. 15, pp. 319-320, 1922.

to Weed, W. H., Mines Handbook, vol. 15, p. 320, 1922. 
them penetrated to the other side of the mountain. On the slope below the tunnel mouths are several shallow shafts and other workings. Plate XVII, $B$, shows most of them. The somewhat unusual character of the workings results from the fact that the mining was done by numerous lessees working under the general supervision of the company's officers. The lessees were paid on the basis of samples of the ore on their dumps, and the ore was transported to the smelter at Hayden by the company.

Character of the deposits.-The property, as can be seen from Plate XVI, is in the fault complex of the Dripping Spring Range. 'The Troy quartzite and the Martin and Tolnado limestones are well represented. In the eastern part Cretaceous andesitic strata crop out. North and west of Chilito is an extensive area of diabase. There are a number of dikes of quartz-mica diorite, and probably other similar rocks. The deposits of the London-Arizona mine developed by the series of tunnels already described are in a mineralized bed near the base of the Martin limestone, known as the O'Carroll ore bed. There are ore bodies at this horizon at a number of places between this locality and the Apex mine, a distance of more than a mile. Most of the ore mined in the London-Arizona tunnels was oxidized material in which copper carbonates were the principal valuable minerals, but some of the ore contained supergene chalcocite, and pyrite was found in a few of the tunnels. Specimens of the ore kindly supplied by Mr. Harry Scott contain malachite, chalcocite, andradite garnet, specularite, quartz, and probably resuvianite. Ore is reported to have been found in nearly all the tumnels, but apparently in small discontinuous masses. The workings in the Troy quartzite on the slope below the tunnels are reported to have found little ore. Wulfenite ore was found in the London-Range shaft, and, according to Mr. Scott, a vein of rhodocrosite 4 feet wide was cut in this shaft at a depth of about 120 feet. In the open cuts and shallow workings in the vicinity of the Curtin shaft some small ore bodies are exposed. These are replacement bodies, which are in large part irregular and not confined by the bedding planes of the limestone. Some of the bodies lie approximately perpendicular to the bedding, but $\mathrm{Mr}$. O'Carroll, who acted as guide here, states that in places the ore makes out along bedding planes. The gangue resembles that of the Christmas ore, containing quartz, andradite garnet, and other minerals, but there is more oxidation than in the ore now exposed at the Christmas mine, and also a wider range in the proportions of the valuable metals present. In places the ore has been mined for lead, principally in the form of cerusite, though galena is reported to have been found near the surface in places. In other outcrops zinc predominated, and a little zinc ore has been mined. Elsewhere oxidized copper ore was found. 


\section{SCHNEIDER GROUP}

The Schneider group of claims, owned by the Gila Canyon Copper Co., is on Schneider Hill, northwest of Chilito and about 5 miles by road from Hayden.

The claims were held by Jake Schneider from some time in the eighties until about 1907, when he sold them to the Hotchkiss Syndicate. The Gila Canyon Copper Co. was formed about 1912 to work the deposits. In 1916 and 1917 the Gila Canyon Consolidated Copper Co. had an option on the property, but later it appears to have reverted to the Gila Canyon Copper Co.

The principal production was made from August, 1916, to January, 1919, when 225 cars of copper ore of a net value of $\$ 129,384$ are reported ${ }^{50}$ to have been shipped to the smelter at Hayden. Work continued into 1920 , but since early in 1921, when the manager, G. B. Chittenden, left, the property has been abandoned.

The Sichneider group consists of 17 unpatented claims on which a considerable amount of development work has been done. There is a tunnel about 1,800 feet long ${ }^{50}$ and numerous shallow workings, as can be seen from Plate XVII, $B$.

The ore bodies on the Schneider group appear to be all in the Troy quartzite, which is underlain and intruded by diabase. Quartzmica diorite intrudes both quartzite and diabase. (See Pl. XVI.) The ore so far found appears to have been in discontinuous replacement bodies, and the known masses are reported to have been largely mined out. A large part of the ore mined was oxidized, but pyritic material enriched by supergene chalcocite was also encountered. The diabase contains disseminated pyrite crystals and is otherwise altered.

\section{APEX MINE}

Location.-The Apex mine, also known as the Lavell, is on the southwest side of the crest of the Dripping Spring Range, threequarters of a mile north of Chilito in a straight line, at an altitude of about 4.250 feet. A wagon road about 5 miles long extends from the mine southeastward to the Globe-Winkelman highway and the Arizona Eastern Railroad at Finney.

History.-The deposit was discovered by Joe Lavell, who was grubstaked by S. O. Stuart about 1914. It was worked by lessees for a time. Then Mrs. K. B. Muller bought a half interest, and she and Lavell worked it. In $191 \tau$ and 1918 it was worked under lease by some New York people. In 1918 Lavell died, leaving Mrs. Muller as the owner. From October, 1922, until his death in 1923, the mine was under lease to Dr. O. M. Roberts, who supplied the

so Weed, W. H., op. cit., p. 274. 
historical information here given. He estimated that $\$ 15,000$ to $\$ 20,000$ worth of gold ore has been shipped to smelters, besides an unknown quantity of high-grade gold ore, some of which is reported to have contained as much as 70 per cent of gold.

Property.-The principal opening is a tunnel over 300 feet long from which stoping has been done laterally and upward. A shaft extends from the surface to the tunnel, and there is an inclined winze approximately below the shaft. A number of other tunnels and shallow shafts have been driven. The property includes a small mill, now out of repair, built about 1901, and a dwelling house.

Character of the deposits.-The ore bodies are in the Martin limestone, which is underlain by the Troy quartzite. Below and intrusive into the quartzite is diabase. (See Pl. XVI.) A dike mapped on Plate XVI as quartz diorite porphyry cuts both quartzite and limestone. This rock differs somewhat from the typical quartz-mica diorite of the Christmas area. Its ferromagnesian constituent was probably originally biotite, but it is now altered to chlorite and associated minerals, does not appear to have been abundant, and is not identifiable in the hand specimen. Quartz phenocrysts are more abundant than in the typical quartz-mica diorite. The feldspar is largely andesine.

The ore deposits are in the Martin limestone at places where the beds have been broken by steeply inclined fractures. The principal ore body is on a fracture zone with a trend somewhat north of east. The ore has been followed for about 300 feet into the mountain along this zone. Ore of good grade is confined vertically to a zone only about 15 feet high and from a few' inches to a number of feet in width, but the mineralized rock extends beyond these limits. In the lower part of the winze is a green rock, evidently a mineralized quartzite, so that it is probable that alteration by the mineralizing solutions extended down into the Troy quartzite. This rock contains quartz, part of which retains its original clastic texture, chlorite, calcite, epidote, and pyrite. According to Doctor Roberts, the ore body here is largely worked out except for pillars and low-grade ore making out along the bedding of the limestone. Other ore shoots may be developed. The ore seen at the time of visit consists largely of quartz, limonite and kindred oxidized iron minerals, cerusite and probably other oxidized lead minerals, and some white alunite. The high-grade ore is stated to have contained much coarse wire gold.

GOLD-COPPER MINES CO.

The property of the Gold-Copper Mines Co. is a little over a quarter of a mile southeast of the Apex mine on the road to Finney. The mine buildings are on the crest of the divide of the Dripping 


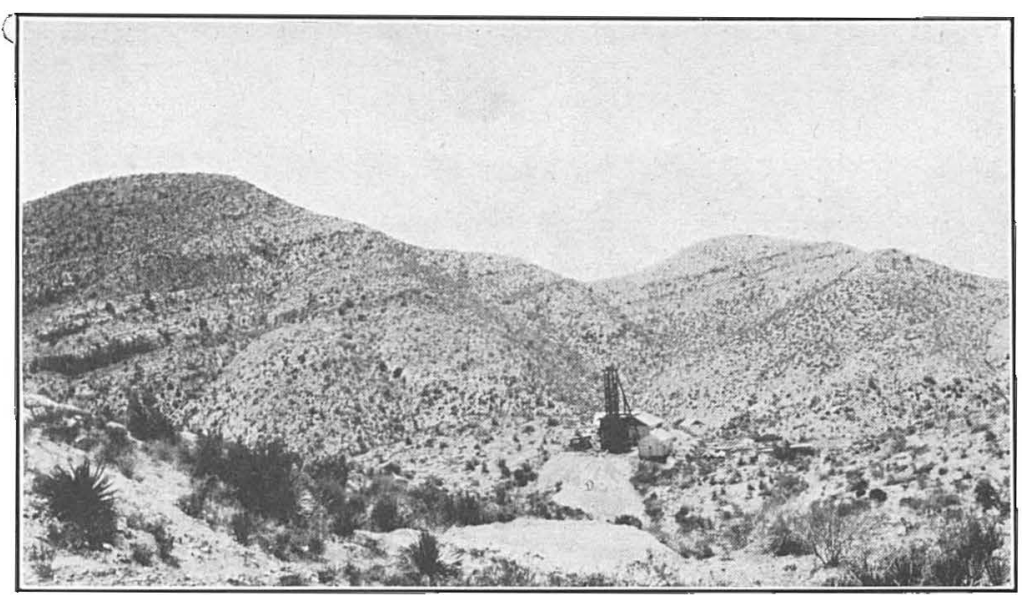

A. CURTIN SHAFT

Tornado Peak in the distance

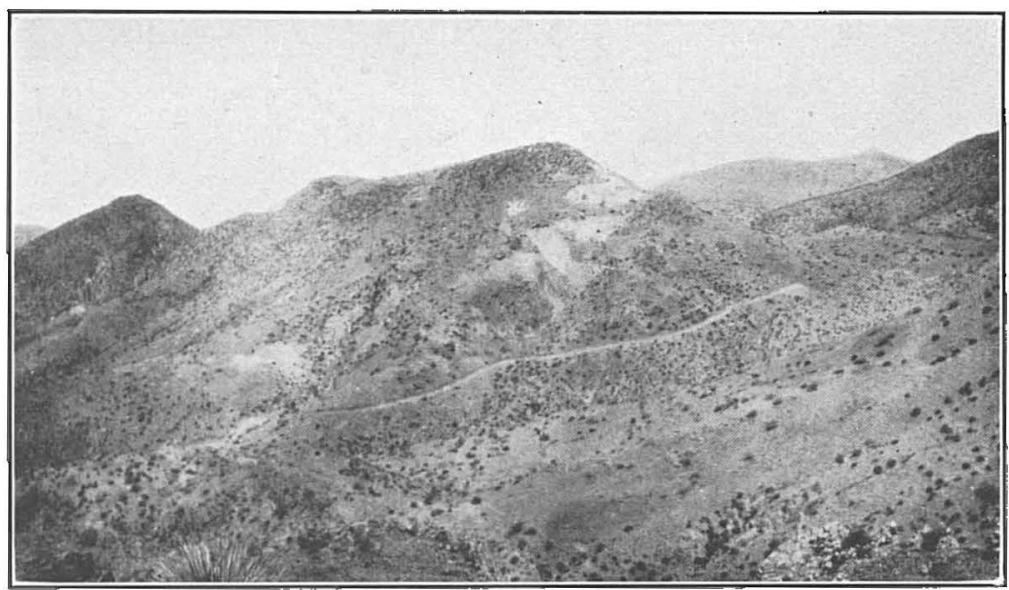

B. WORKINGS ON THE SCHNEIDER GROUP OF THE GILA CANYON COPPER CO. 
Spring Range, at an altitude of about 4,250 feet, and the workings are near by on the northeast slope of the ridge.

The deposit was located about 1914 by S. O. Stewart, who gave J. H. Ramsey a half interest in it for working it. Later the GoldCopper Mines Co. was formed and additional claims were located. In 1921 Ramsey and Doctor Ruff acquired an option on the property and did some work. A mill was completed in the fall of 1921, but no ore has been shipped, and when visited in June, 1922, the property was idle.

The mine is developed by several tunnels one above another. At the mouth of the lowest is the mill, which is equipped with amalgamation plates, two concentrating tables, and, below these, cyanide tanks. It is reported to have been in operation 11 days and to have treated 23 tons of ore. On the ridge above the mine are several houses, one of which is occupied by J. J. Hill, who was of assistance in the examination of the property.

The country rock of the mine is principally the Martin limestone. The tunnels follow a vein striking about N. $80^{\circ}$ W., with nearly vertical dip. One tunnel follows another and smaller mineralized fissure. In a number of places altered igneous rock forms the south wall of the main vein. In the hand specimen this is a fine-grained dull-green rock speckled with numerous small white feldspar phenocrysts. Under the microscope it is seen to be so highly altered that close determination of its original character is impossible. It is an aggregate of chlorite, epidote, residual bits of feldspar, and indeterminate alteration products. The rock is probably an altered intrusive andesite, perhaps related to the dioritic dikes that are common in this region. The limestone along the fissure is mineralized for a width of a foot or two. In the central part is a seam several inches wide consisting largely of long, narrow, well-formed quartz crystals, a feature not observed in any of the other deposits examined. In several places the mineralization extended short distances away from the vein along the bedding planes of the limestone. A little copper-stained pyrite was noted at one place, and at the mouth of one tunnel was a small pile of mineralized rock containing malachite.

\section{HOGVALL PROSPECT}

Anton Hogvall has a prospect on the south side of a gulch threequarters of a mile almost due west of Tornado Peak and somewhat over half a mile southwest of Chilito. Here several short tunnels have been opened on mineralized stringers and irregular gossan bodies in the Martin limestone. Pyrite was seen on the dump of one tunnel. The ore is reported to carry gold. 


\section{SEVENTY NINE MINE}

Location.-The Seventy Nine mine is in the Ray quadrangle, a little less than 2 miles northwest of Tornado Peak and $41 / 2$ miles northwest of Hayden in air lines. The principal workings and mine buildings are on the northwest side of a wash at an altitude of somewhat more than 3,300 feet above sea level, and there are prospect holes along the streamway above this.

History.-The deposit was located in 1879 by Mike O'Brien and his brother Pat, but little work was done on it until December, 1919. From that date until April 27, 1922, the mine was held by the Continental Commission Co., which is reported to have shipped about 3,000 tons of ore averaging 24 per cent of lead, 1.75 per cent of copper, and 4 ounces of silver and 80 cents in gold to the ton. In April, 1922, the mine was taken over by the Seventy Nine Mining Co., and in June, 1922, the managers reported that shipments of about 50 tons a day were being made of ore averaging about the same as that previously shipped. Recently ${ }^{52}$ the mine has been ordered reconveyed to the Continental Commission Co. as a result of litigation.

Property.-The property comprises 23 claims. $^{53}$ The mine has been developed by two tunnels, one above the other, with irregular stopes from them. Most of the stoping now in progress starts from the upper tunnel. The ore is sent down chutes to the lower tunnel and trammed to the surface. There is a winze down 70 feet on a $35^{\circ}$ slope from the lower tunnel. A short distance up the gulch from the mine are the office, boarding house, and a few other buildings. Not far from the boarding house is a prospect shaft, and a few hundred yards farther upstream is a tunnel from which a little stoping has been done. Other prospect workings are scattered over the property.

Character of the deposits.-The country rock is the Tornado limestone. In the northeastern part of the mine is a dike of altered dioritic rock flanked by fault breccia, and near the mouth of the lower tunnel some irregular masses of comparatively fresh quartzmica diorite are exposed. The ore has been formed as replacement bodies of galena along certain beds in the limestone separated by silicified beds, perhaps originally somewhat shaly, which are also more or less mineralized in places. About five different beds of ore from 3 to 5 feet, thick are reported to have been found. There appears to be more unaltered galena in the upper stopes than below, but throughout the mine a large part of the ore is cerusite. Anglesite and small amounts of azurite and malachite are also present.

52 Eng. and Min. Jour.-Press, vol. 115, p. 862, 1923.

s3 Weed, W. H., Mines Handbook, vol. 15, p. 254, 1922. 
At the shallow shaft near the boarding house the ore, which is an irregular body formed by the replacement of limestone, is thoroughly oxidized. The minerals recognized are wulfenite, cerusite, limonite, andradite garnet, quartz, calcite, and a little hydrous manganese oxide and malachite. There is also a small amount of a yellow powdery material, probably an oxidized lead mineral, but it was impossible to separate enough for a conclusive test. Garnet is also reported in outcrops of some of the ore beds at the main mine. The tunnel farther up the gulch contains oxidized ore, but here copper is the metal sought, and no lead is reported to be present. The ore is stated to carry several ounces of silver to the ton. This deposit is also in the Tornado limestone but appears to have been formed along a fissure instead of along the bedding. The minerals recognized are chrysocolla, malachite, cuprite, black copper oxide, hematite, magnetite, quartz, garnet, and calcite.

\section{COLUMBIA TINE}

Locution.-The Columbia mine of the Dripping Springs Mines Corporation is in a tributary gulch on the south side of Dripping Spring Valley about three-quarters of a mile west of the point where the highway to Globe swings north out of the valley and 2 miles east of Troy. It is about $181 / 2$ miles from Winkelman and 12 miles from the terminus of the Arizona Eastern Railroad at Christmas station.

History-Most of the claims were located by J. W. Read, part of them in 1901. The Dripping Springs Copper Co. acquired the property about 1915 and was reorganized into the present company about 1920. Most of the development work was done in this year, and some copper ore was shipped. When visited in June, 1922, development work was in progress under Mr. A. T. Copley, superintendent, who kindly furnished the historical and other data regarding the mine. In the fall of 1922 exploration by diamond drilling from the floor of the principal tunnel mas started, and an ore body 10 feet wide is reported to have been encountered..$^{54}$

Property.-The Columbia group comprises about 20 claims. The Dripping Springs Mines Corporation also owns the Pearl group ${ }^{55}$ of claims, near Mammoth. At the Columbia mine there are a number of buildings, an air compressor, and other equipment. The principal underground workings consist of a tunnel about 550 feet long with a crosscut at the end of the tunnel extending 950 feet south and 350 feet north and a shallow winze at the north end.

st Fing. and Min. Jour.-Press, vol. 115, p. 688, 1923.

bo Weed, W. H., op. cit., p. 265. 
Some stoping has been done, and there are several branch drifts off the crosscuts and smaller workings elsewhere.

Character of the deposits.-The rocks in this vicinity are a complex of small fault blocks of Paleozoic sedimentary rocks and intrusive diabase, with intrusions of quartz diorite porphyry and granodiorite only short distances away. Plate XVI shows the general features of the geology, but is on too small a scale to illustrate fully the complexity of the faulting. The rock mapped by Ransome as quart\% diorite porphyry is probably equivalent to that called quartz-mica diorite in the present report. Most of the rock exposed underground is diabase, but there is a block of limestone supposed to belong to the Mescal limestone, and at the north end of the crosscut some metamorphosed shaly rock is exposed, perhaps also a part of the Mescal limestone. Mr. Copley states that five fissures showing mineralization are known. They strike in general nearly east and $\operatorname{dip} 70^{\circ}-80^{\circ} \mathrm{S}$. Gouge and altered country rock without much quartz in belts 3 to 8 feet wide occur along these fissures, widening out into the limestone where this rock forms one of the walls. Small bodies of copper carbonate ore have been found and stoped in places. Mr. Copley states that cuprite was noted in cracks in one of the veins, and small amounts of pyrite and chalcopyrite have been observed. In the altered shale at the north end of the workings a bed about 4 feet thick has been replaced by vesuvianite, magnetite, and doubtless other minerals. Picked samples from this bed are reported to contain 3 to 7 per cent of zinc, but no zinc minerals appear to be present in the specimen collected. Garnet is probably present in places, and some specularite is associated with the magnetite showing incipient replacement along octahedral partings.

\section{MCHUR PROSPECT ${ }^{56}$}

In Seventy-nine Gulch there was in $191 \tau$ a vanadium prospect owned by Mac McHur. The exact location is not known, but it is possible that the deposits are on the ground of the present Seventy Nine Mine. Irregular masses of gossanlike material containing siderite, wulfenite, and vanadinite crop out in the gulch for about a quarter of a mile, and there are shallow workings at intervals. The country rock is the Tornado limestone, with diabase coming in near by and possibly against it in places. About a mile above this is an outcrop of ferruginous quartz at the contact of limestone and diabase, called the Iron Spike vein. A little wulfenite and vanadinite and some copper staining occur here. About a mile below the McHur prospect a small mill has at one time been operated by Mr. Boykin, of Tucson.

\footnotetext{
${ }^{50}$ From notes by F. L. Hess, of the U. S. Geol. Surrey, taken in Aprll, 1917.
} 


\section{PREMIER GROUP 57}

The Premier group, owned by S. O. Stewart, comprises 10 unpatented claims on the south side of Dripping Spring Valley 2 miles northwest of Christmas. 'The location shown on Plate $\mathrm{X}$ is only approximate. The deposit is developed by several pits and by an open cut about 25 feet long, with a drift from one end extending 20 feet to the east and a wirze 12 feet cleep at the end of the drift. The country rock is the Tornado limestone. The vein strikes about magnetic east, dips nearly vertically, and can be traced for about half a mile on the surface. A dike of quartz porphyry about 60 feet wide cuts the vein at a small angle. It is stained with iron oxide and appears to contain a little vanadinite. At the open cut mentioned the spongy gossan-like material extends out north of the vein and lies nearly flat along the bedding of the limestone. Above the drift the limestone is crushed and recemented by caliche-like material. 'The vein ranges from 10 inches to 3 feet in width and contains iron-stained, spongy quartz with vugs and cracks lined with thin coatings of vanadinite and wulfenite.

\section{C. \& B. GROUP $5 r$}

The C. \& B. group, owned by E. E. Cutler and Calvin Bywater, is on the south side of Dripping Spring Valley, about 9 miles above its mouth. It comprises five claims and is developed by a 20 -foot shaft and two tunnels, 30 and 60 feet long, with a 10-foot winze below the shorter one. The tunnels are on a vein of oxidized material, striking approximately $\mathrm{N} .60^{\circ} \mathrm{E}$. and dipping southeast along the contact between limestone and diabase, and the shaft is on a branch of the vein, also on the contact between the limestone block and diabase but striking N. $35^{\circ} \mathrm{W}$. and dipping northeast. Near by is a small outcrop of red granitic rock. Movement and brecciation have taken place along the vein fissures. The vein matter is well oxidized and for the most part soft, although silicified in places. Vanadinite and wulfenite are present in the soft material and also form coatings on brecciated diabase for a width of a few feet. Cavities left by galena crystals that had been oxidized and removed were noted at one place.

These contain vanadinite. There are some small veins on the property. A little ore has been mined, and some is reported to have been shipped during the war.

${ }^{67}$ From notes by F. L. Hess, of the U. S. Geol. Survey, taken in April, 1917. 



\section{INDEX}

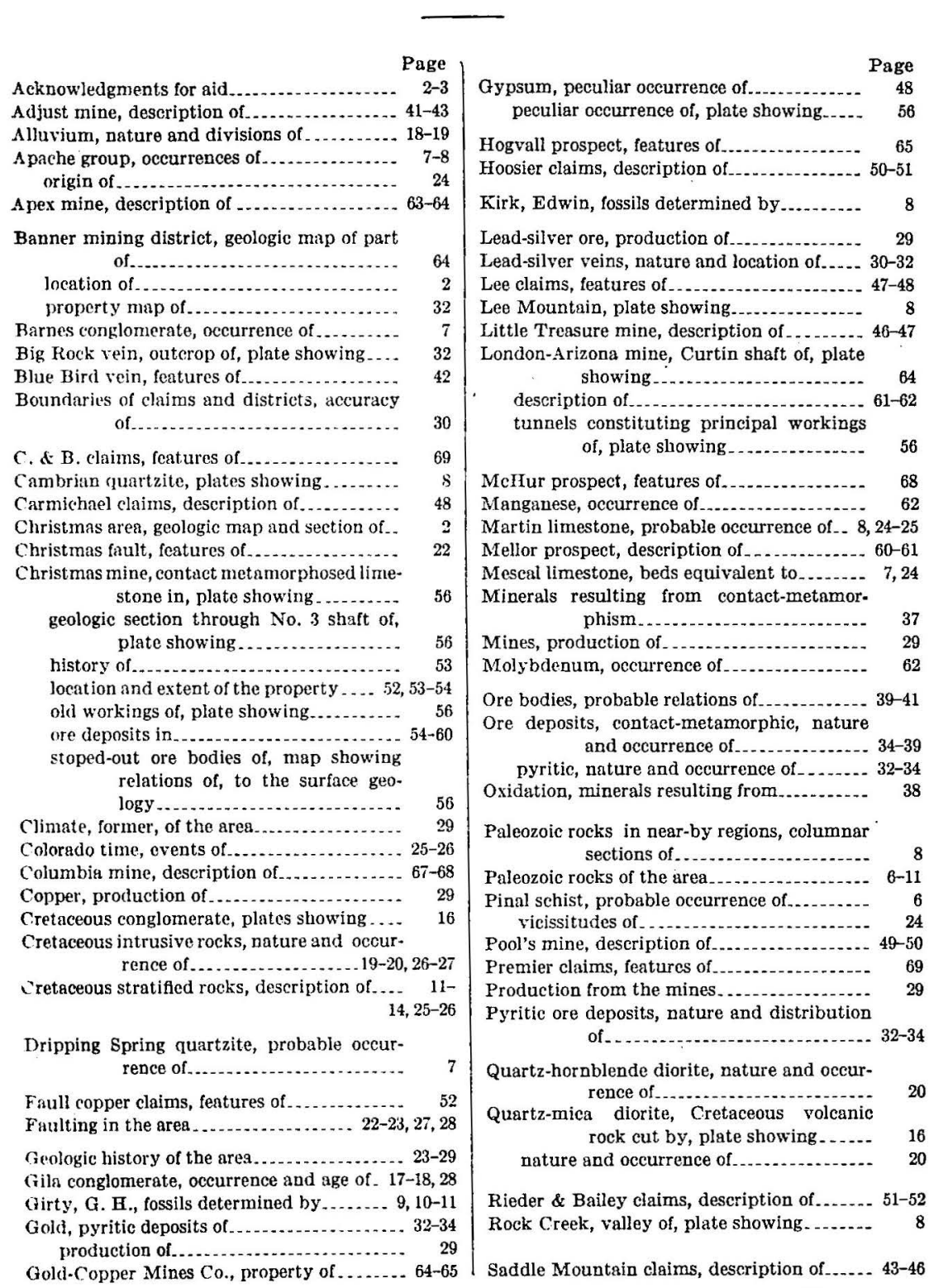


Page

Saddle Mountain mining district, location of property map of.

Scanlan conglomerate, occurrence of .........

Schneider claims, description of workings of, plate showing

Scope of the report

2 Tertiary conglomerate, older, plates showing Page

Seventy-nine mine, description of

Tertiary stratified rocks, older............. 15-17, 28

Topography of the area

Tornado limestone, plate showing ......... 8, 16

probable occurrence of................. 8-11

sill of altered trap in, plate showing

Stratigraphy of the area, general features of.

Structure of the rocks

Troy quartzite, possible occurrence of....... 7-8

Two Queens mine, description of ............ 48-49

Vanadium, mining of ........................

Summary of the report

Tablelands, The, formations exposed in ...... 15-17 Tertiary conglomerates on, plates showing occurrences of

Whitetail conglomerate, probable occurrence 16 of . . 
Lithomount

Pamphlet

Binder

Gaylord Bros. Inc.

Makers

Syracuse, N. $\mathbf{X}$.

PAT. JAN 21, 1808 


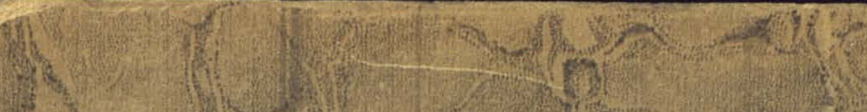

2.5

(is.

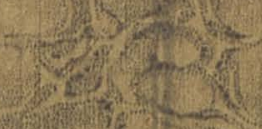

(1)

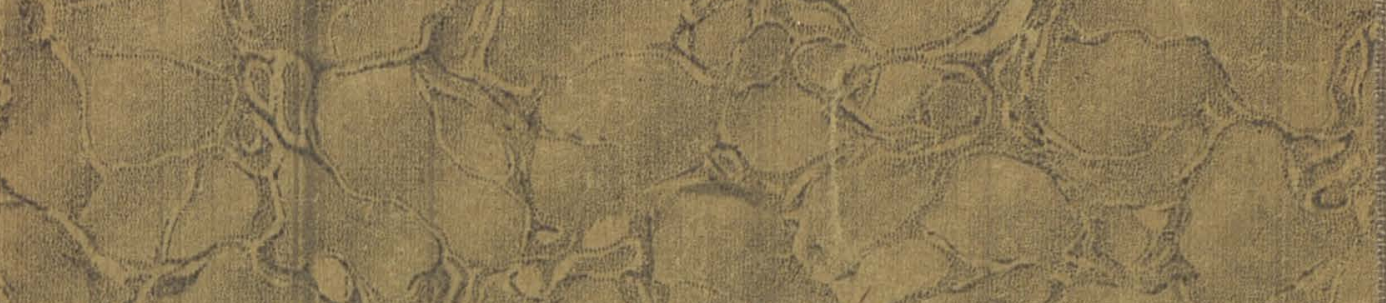

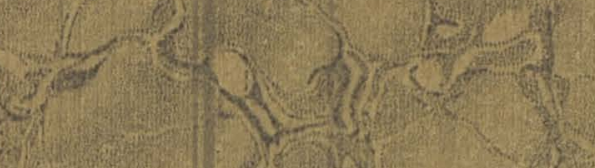

$+4 x^{2}$

(5)

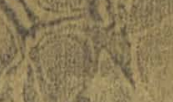

f.

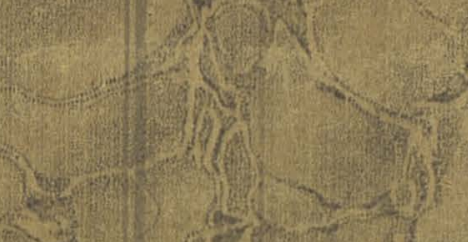

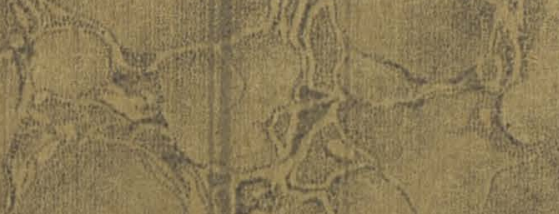

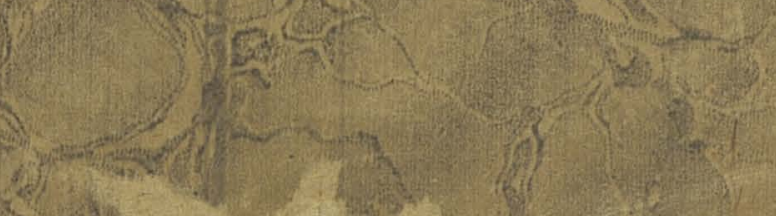

Pr.tis

(x)

$1043^{2}-2 x=$

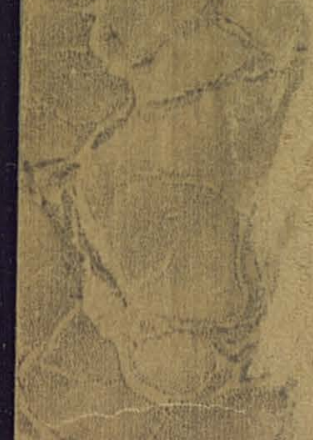

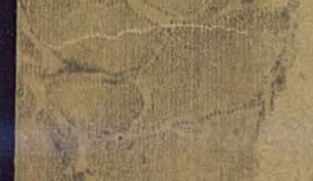

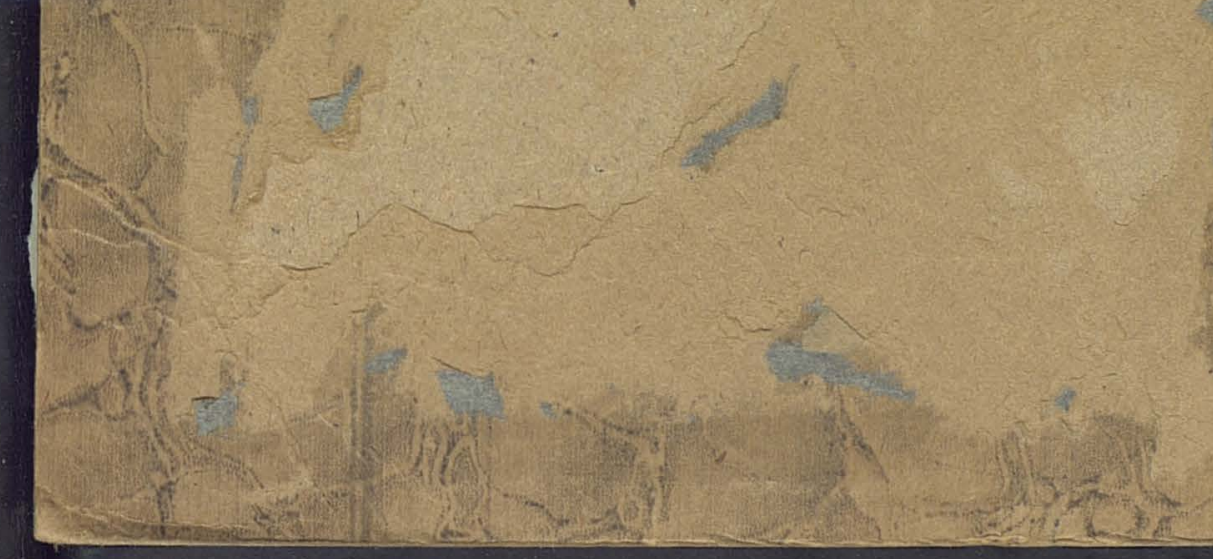

